Cochrane Database of Systematic Reviews

\title{
Hypothermia for traumatic brain injury (Review)
}

Lewis SR, Evans DJW, Butler AR, Schofield-Robinson OJ, Alderson P

Lewis SR, Evans DJW, Butler AR, Schofield-Robinson OJ, Alderson P.

Hypothermia for traumatic brain injury.

Cochrane Database of Systematic Reviews 2017, Issue 9. Art. No.: CD001048.

DOI: 10.1002/14651858.CD001048.pub5.

www.cochranelibrary.com 
TABLE OF CONTENTS

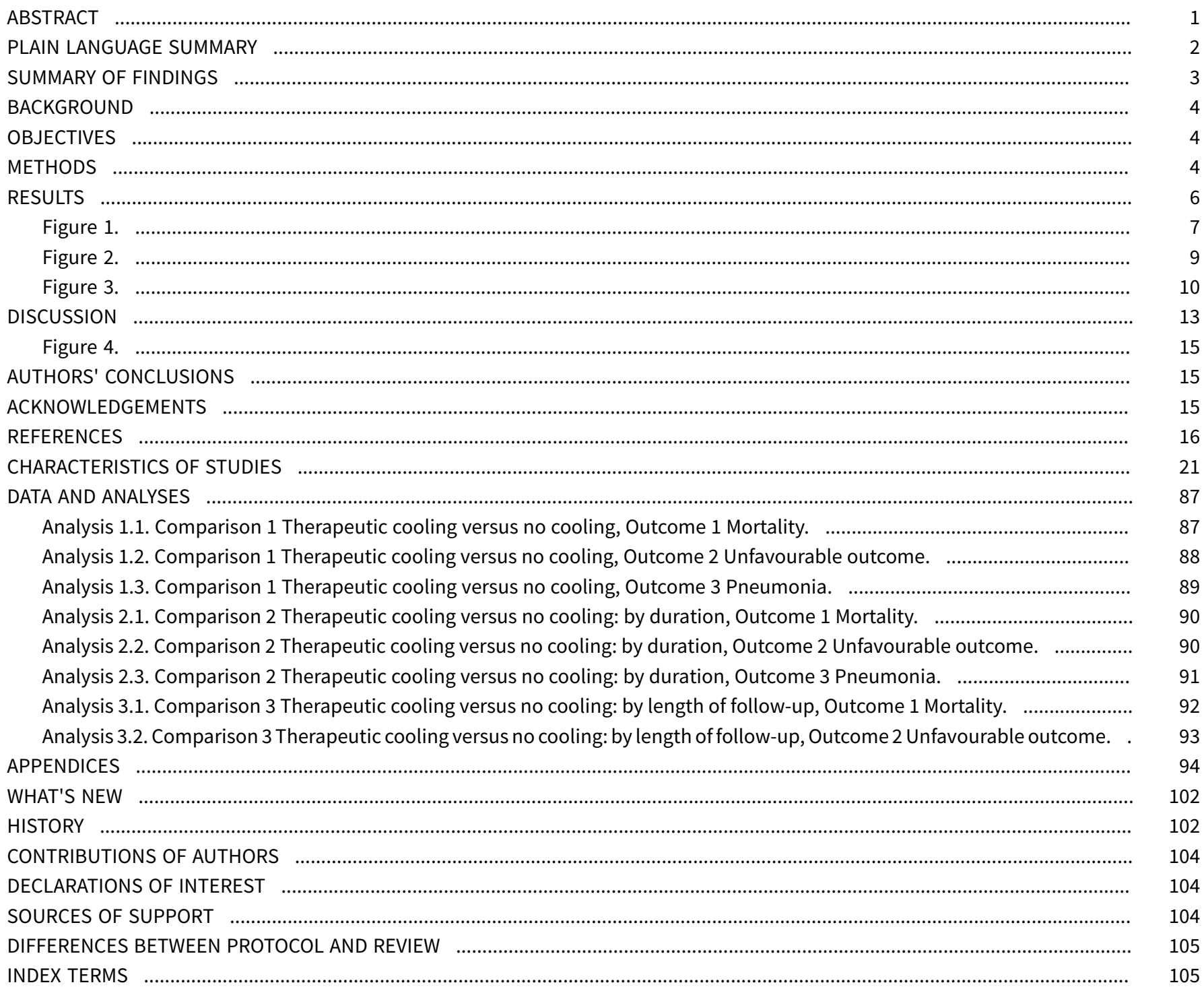


[Intervention Review]

\section{Hypothermia for traumatic brain injury}

Sharon R Lewis ${ }^{1}$, David JW Evans², Andrew R Butler¹, Oliver J Schofield-Robinson³, Phil Alderson4

1Patient Safety Research Department, Royal Lancaster Infirmary, Lancaster, UK. 2Lancaster Health Hub, Lancaster University, Lancaster, UK. ${ }^{3}$ Research and Development, Royal Lancaster Infirmary, University Hospitals of Morecambe Bay, NHS, Lancaster, UK. ${ }^{4}$ National Institute for Health and Care Excellence, Manchester, UK

Contact: Sharon R Lewis, Patient Safety Research Department, Royal Lancaster Infirmary, Pointer Court 1, Ashton Road, Lancaster, LA1 4RP, UK.Sharon.Lewis@mbht.nhs.uk, sharonrlewis@googlemail.com.

Editorial group: Cochrane Injuries Group.

Publication status and date: New search for studies and content updated (no change to conclusions), published in Issue 9, 2017.

Citation: Lewis SR, Evans DJW, Butler AR, Schofield-Robinson OJ, Alderson P. Hypothermia for traumatic brain injury. Cochrane Database of Systematic Reviews 2017, Issue 9. Art. No.: CD001048. DOI: 10.1002/14651858.CD001048.pub5.

Copyright @ 2017 The Cochrane Collaboration. Published by John Wiley \& Sons, Ltd.

\section{A B S T R A C T}

\section{Background}

Hypothermia has been used in the treatment of brain injury for many years. Encouraging results from small trials and laboratory studies led to renewed interest in the area and some larger trials.

\section{Objectives}

To determine the effect of mild hypothermia for traumatic brain injury (TBI) on mortality, long-term functional outcomes and complications.

\section{Search methods}

We ran and incorporated studies from database searches to 21 March 2016. We searched the Cochrane Injuries Group's Specialised Register, Cochrane Central Register of Controlled Trials (CENTRAL, The Cochrane Library), MEDLINE (OvidSP), Embase Classic+Embase (OvidSP), PubMed, ISI Web of science (SCI-EXPANDED, SSCI, CPCI-S \& CPSI-SSH), clinical trials registers, and screened reference lists. We also re-ran these searches pre-publication in June 2017; the result from this search is presented in 'Studies awaiting classification'.

\section{Selection criteria}

We included randomised controlled trials of participants with closed TBI requiring hospitalisation who were treated with hypothermia to a maximum of $35^{\circ} \mathrm{C}$ for at least 12 consecutive hours. Treatment with hypothermia was compared to maintenance with normothermia $\left(36.5\right.$ to $\left.38^{\circ} \mathrm{C}\right)$.

\section{Data collection and analysis}

Two review authors assessed data on mortality, unfavourable outcomes according to the Glasgow Outcome Scale, and pneumonia.

\section{Main results}

We included 37 eligible trials with a total of 3110 randomised participants; nine of these were new studies since the last update (2009) and five studies had been previously excluded but were re-assessed and included during the 2017 update. We identified two ongoing studies from searches of clinical trials registers and database searches and two studies await classification.

Studies included both adults and children with TBI. Most studies commenced treatment immediately on admission to hospital or after craniotomies and all treatment was maintained for at least 24 hours. Thirty-three studies reported data for mortality, 31 studies reported data for unfavourable outcomes (death, vegetative state or severe disability), and 14 studies reported pneumonia. Visual inspection of the results for these outcomes showed inconsistencies among studies, with differences in the direction of effect, and we did not pool these 
data for meta-analysis. We considered duration of hypothermia therapy and the length of follow-up in collected data for these subgroups; differences in study data remained such that we did not perform meta-analysis.

Studies were generally poorly reported and we were unable to assess risk of bias adequately. Heterogeneity was evident both in the trial designs and participant inclusion. Inconsistencies in results may be explained by heterogeneity among study participants or bias introduced by individual study methodology but we did not explore this in detail in subgroup or sensitivity analyses. We used the GRADE approach to judge the quality of the evidence for each outcome and downgraded the evidence for mortality and unfavourable outcome to very low. We downgraded the evidence for the pneumonia outcome to low.

\section{Authors' conclusions}

Despite a large number studies, there remains no high-quality evidence that hypothermia is beneficial in the treatment of people with TBI. Further research, which is methodologically robust, is required in this field to establish the effect of hypothermia for people with TBI.

\section{PLAIN LANGUAGE SUMMARY}

\section{Hypothermia (body temperature cooling) for people with an injury to the brain}

\section{Review question}

What is the effect of mild hypothermia (body temperature cooling) following a brain injury on whether a person dies, has a poor outcome, or gets a type of severe chest infection (pneumonia)?

\section{Background}

Hypothermia has been used for many years to treat people who have had a severe brain injury. This involves cooling the head or the whole body to a temperature below normal body temperature. We aimed to assess whether people treated with hypothermia after a brain injury are less likely to die or have a poor outcome (which we defined as death, coma or severe disability) and whether using hypothermia might increase the risk of a severe chest infection called pneumonia.

\section{Search date}

Evidence is current to March 2016.

\section{Study characteristics}

We included 37 studies with 3110 participants. In each trial, patients were randomly divided into two groups: one group remained at normal body temperature of 36.5 to $38^{\circ} \mathrm{C}$, and the other group was cooled to a maximum of $35^{\circ} \mathrm{C}$ for at least 12 hours.

\section{Key results}

We did not combine results of these studies to assess whether hypothermia improves patient outcome. This was because the results had large differences which we could not explain. We identified some differences in the ways in which the studies were carried out and the participants that study authors had recruited, but we did not assess whether this could explain the differences in results. We did not have enough good quality evidence that was sufficiently similar to be confident that treating people who have had a severe brain injury with hypothermia will reduce the incidence of death or severe disability, or increase the incidence of pneumonia.

\section{Quality of evidence}

Many of the studies were not well reported and we were unable to assess whether differences between the quality of the studies may also have affected our results. We used the GRADE approach to judge the quality of evidence. We judged the evidence for death or severe disability to be very low quality, and the evidence for pneumonia to be low quality. 


\section{SUMMARY OF FINDINGS}

\section{Summary of findings for the main comparison. Hypothermia for traumatic brain injury}

\section{Hypothermia for traumatic brain injury}

Patient or population: patients with traumatic brain injury

Settings: hospitals; in Australia, Canada, China, Czech Republic, Germany, Japan, Malaysia, New Zealand, UK, USA

Intervention: hypothermia versus normothermia

\begin{tabular}{|c|c|c|c|}
\hline Outcomes & $\begin{array}{l}\text { No of Participants } \\
\text { (studies) }\end{array}$ & $\begin{array}{l}\text { Quality of the evi- } \\
\text { dence } \\
\text { (GRADE) }\end{array}$ & Comments \\
\hline $\begin{array}{l}\text { Mortality at end of } \\
\text { follow-up }\end{array}$ & $\begin{array}{l}2944 \\
(32 \text { studies } a)\end{array}$ & $\begin{array}{l}\oplus \odot \odot \ominus \\
\text { very low b }\end{array}$ & $\begin{array}{l}\text { Data not combined in meta-analysis. Visual inspection of data } \\
\text { showed variation in differences of effect not explained by sub- } \\
\text { group analysis }\end{array}$ \\
\hline $\begin{array}{l}\text { Unfavourable out- } \\
\text { come at end of fol- } \\
\text { low-up }\end{array}$ & $\begin{array}{l}2620 \\
(27 \text { studies })\end{array}$ & $\begin{array}{l}\oplus \ominus \ominus \ominus \\
\text { very low } d\end{array}$ & $\begin{array}{l}\text { Data not combined in meta-analysis. Visual inspection of data } \\
\text { showed variation in differences of effect not explained by sub- } \\
\text { group analysis }\end{array}$ \\
\hline Pneumonia & $\begin{array}{l}693 \\
(14 \text { studiese) }\end{array}$ & $\begin{array}{l}\oplus \oplus \ominus \ominus \\
\text { low }^{f}\end{array}$ & $\begin{array}{l}\text { Data not combined in meta-analysis. Visual inspection of data } \\
\text { showed variation in differences of effect }\end{array}$ \\
\hline
\end{tabular}

GRADE Working Group grades of evidence

High quality: Further research is very unlikely to change our confidence in the estimate of effect.

Moderate quality: Further research is likely to have an important impact on our confidence in the estimate of effect and may change the estimate.

Low quality: Further research is very likely to have an important impact on our confidence in the estimate of effect and is likely to change the estimate.

Very low quality: We are very uncertain about the estimate.

aWe identified 33 studies that reported data for mortality, with comparable data available for 32 studies

bFew studies had sufficiently described random sequence generation and concealment; downgraded one level for study limitations. Some inconsistencies between studies, not explained by per protocol subgroup analyses; downgraded one level for inconsistency. Some differences in study population between studies; Andrews 2015 included participants with less severe head injury, and with a longer delay in treatment; downgraded one level for indirectness.

cWe identified 29 studies that reported data for unfavourable outcome, with comparable data available for 26 studies.

dFew studies had sufficiently described random sequence generation and concealment; downgraded one level for study limitations. Some inconsistencies between studies not explained by per protocol subgroup analyses and we noted a moderate level of statistical heterogeneity; downgraded two levels for inconsistency. Some differences in study population between studies; Andrews 2015 included participants with less severe head injury, and with a longer delay in treatment; downgraded one level for indirectness.

eWe identified 14 studies that reported data for pneumonia, with comparable data available for 12 studies.

fSome inconsistencies between studies, not explained by per protocol subgroup analyses; downgraded one level for inconsistency. Some differences in study population between studies; Andrews 2015 included participants with less severe head injury, and with a longer delay in treatment; downgraded one level for indirectness. 


\section{B A C K G R O U N D}

\section{Description of the condition}

Traumatic brain injury (TBI) is a major cause of death and disability amongst a predominantly young population. An estimated 10 million people worldwide experience severe brain injury every year (Langlois 2006). There is, however, a lack of evidence about effective therapies in the acute care of brain-injured patients, especially children (Adelson 2003). A long-term effort to review the literature and produce management guidelines by the American Association of Neurological Surgeons (Bullock 1996; Bullock 2007; Carney 2016; Kirkpatrick 1997) could make few definitive statements about treatment effectiveness that were supported by strong evidence from randomised studies. These guidelines include recommendations based on high-quality evidence related to steroids, and moderate-quality evidence related to decompressive craniectomy, nutrition, infection prophylaxis, and seizure prophylaxis; other recommendations were based on a lowquality body of evidence.

\section{Description of the intervention}

Methods used to induce therapeutic cooling include use of cooling blankets, ice lavage or air-cooling devices. Mild to moderate hypothermia, cooling to 32 to $35^{\circ} \mathrm{C}$, has been used in the treatment of brain injury for over 50 years (Fay 1945). Although there were several promising experimental studies (Clasen 1968; Laskowski 1960) and case series (Sedzimir 1959; Shapiro 1974), no controlled clinical studies were performed and the therapy fell from favour. During the 1990s several investigators reported encouraging results from phase II and III randomised clinical trials (Clifton 1995; Marion 1997; Shiozaki 1993), corroborated by consistent findings of high levels of cerebral protection associated with systemic cooling in well-validated laboratory models of global ischaemia (Busto 1987). The early trials were small, single-centre investigations, which were sufficiently promising to lead to larger, multicentre trials.

\section{How the intervention might work}

Originally it was thought that the primary mechanism of action of temperature control therapy was a reduction in cerebral metabolic rate (Bering 1961). There is now evidence that mild hypothermia might also influence the excessive post-traumatic release of excitatory neurotransmitters (Busto 1989) and attenuate the opening of the blood-brain barrier (Smith 1996). The main risks associated with induced systemic hypothermia are an increased risk of sepsis and pneumonia, coagulation abnormalities, and possible myocardial ischaemia and atrial fibrillation (Schubert 1995).

\section{Why it is important to do this review}

A previous version of this review did not find clear evidence of the beneficial effects of hypothermia (Sydenham 2009b). Interest has continued in the use of hypothermia for TBI as well as in other conditions with neurological damage, and research has continued. It was important to update the review to include the most recent published data.

\section{O B JE C T IVES}

To determine the effect of mild hypothermia for TBI on mortality, long-term functional outcomes and complications.

\section{METHODS}

\section{Criteria for considering studies for this review Types of studies}

We searched for all randomised controlled trials (RCTs) of mild hypothermia versus control.

\section{Types of participants}

We included participants with any closed TBI requiring hospitalisation. We included studies in which participants had open and closed head injuries if fewer than $10 \%$ of participants were described as having an open head injury.

\section{Types of interventions}

We included therapeutic cooling, either locally or systemically, by means of a fluid-filled cooling blanket, a 'bear-hugger' air-cooling device, ice water lavage, any combination of the above, or other methods, to a target temperature of at most $35^{\circ} \mathrm{C}$ for a period of at least 12 consecutive hours. Cooling could have begun immediately upon admission to the intensive care unit or be deferred until intracranial pressure (ICP) became uncontrollable by conventional management. We compared maintenance of hypothermia with maintenance of normothermia. We defined normothermia as a target temperature of 36.5 to $38^{\circ} \mathrm{C}$.

\section{Types of outcome measures}

\section{Primary outcomes}

1. All-cause mortality at the end of the follow-up period.

2. Unfavourable outcome at the end of the follow-up period.

Unfavourable outcome was defined as a Glasgow Outcome Scale (GOS) score of "severe disability", "persistent vegetative state", or "death"; or an equivalent measure if a GOS score was not presented.

\section{Secondary outcomes}

1. Frequency of pneumonia.

\section{Search methods for identification of studies}

To reduce publication and retrieval bias we did not restrict our search by language, date or publication status.

\section{Electronic searches}

The Cochrane Injuries Group's Information Specialist searched the following databases:

1. Cochrane Injuries Group specialised register (21 March 2016);

2. Cochrane Central Register of Controlled Trials (CENTRAL, The Cochrane Library) (issue 2 of 12, 2016);

3. Ovid MEDLINE(R), Ovid MedLINE(R) In-Process \& Other Non-Indexed Citations, Ovid MEDLINE(R) Daily and Ovid OLDMEDLINE(R) (1946 to 21 March 2016);

4. Embase Classic + Embase (OvidSP) (1947 to 21 March 2016);

5. ISI Web of Science: Science Citation Index Expanded (SClEXPANDED) (1970 to March 2016); and

6. ISI Web of Science: Conference Proceedings Citation IndexScience (CPCI-S) (1990 to March 2016). 
We re-ran this search prior to publication on 1 June 2017, screened the results and placed relevant studies in Characteristics of studies awaiting classification. We will incorporate these in the next review update as appropriate.

One review author (Sharon R Lewis (SRL)) searched the following clinical trials registers:

1. Clinicaltrials.gov (www.clinicaltrials.gov) (accessed 21 September 2016);

2. ISRCTN Registry (http://www.isrctn.com/) (accessed 21 September 2016);

3. WHO International Clinical Trials Registry Platform (http:// apps.who.int/trialsearch/) (accessed 21 September 2016).

Search strategies and notes are reported in Appendix 1. We adapted the MEDLINE search strategy as necessary for the other databases. We also used search filters, a modified version of the Cochrane Highly Sensitive Search Strategies, for identifying randomised trials in MEDLINE and Embase (Lefebvre 2011). Previous search strategies are reported in Appendix 2.

\section{Searching other resources}

We completed forward citation tracking of all new included studies identified from the searches in 2016. We completed backward citation searches of relevant review articles identified from these searches (Clifton 2011b; Crossley 2014; Georgiou 2013).

\section{Data collection and analysis}

\section{Selection of studies}

Two review authors screened the search results (SRL with Andrew Butler (AB), David Evans (DE), or Phil Alderson (PA)). We then retrieved full-text copies of relevant records. We independently compared the trial design with the inclusion criteria for this review. We resolved disagreements by discussion.

\section{Data extraction and management}

Two review authors (SRL with AB, DE, PA or Oliver SchofieldRobinson (OSR)) extracted the following information from each trial:

- Methods: type of study design, setting, dates of study, funding sources.

- Participants: number randomised to each group, baseline characteristics (to include age, gender, type of injury, Glasgow Coma Score on admission).

- Intervention: details to include method of cooling, target temperature, time of initiation, duration of cooling and details of re-warming.

- Outcomes: all outcomes reported by study authors.

We considered applicability of information from individual studies and generalisability of the data to our intended study population (i.e. the potential for indirectness in our review). In the case of several publications of the same study, we identified a key reference and checked the data in this report for consistency against the other associated publications.

Extracted data were entered into Review Manager (RevMan) by SRL.

Hypothermia for traumatic brain injury (Review)

Copyright $\odot 2017$ The Cochrane Collaboration. Published by John Wiley \& Sons, Ltd.

\section{Assessment of risk of bias in included studies}

We assessed study quality, study limitations and the extent of potential bias using the Cochrane 'Risk of bias' tool (Higgins 2011). We considered the following domains:

- Sequence generation (selection bias).

- Allocation concealment (selection bias).

- Blinding of participants, personnel and outcomes assessors (performance and detection bias).

- Incomplete outcome data (attrition bias).

- Selective outcome reporting (reporting bias).

For each domain, two review authors (SRL with $A B, D E$, OSR or $\mathrm{PA}$ ) judged whether study authors had made sufficient attempts to minimize bias in their study design. Where necessary these judgements were made against each separate outcome. We made judgements using three measures: high, low, or unclear risk of bias.

\section{Measures of treatment effect}

We collected dichotomous data for mortality, unfavourable outcome and pneumonia. Study authors assessed participants using the Glasgow Outcome Scale, or equivalent, to report the number of participants who had an unfavourable outcome; this combined the number of participants who had died, those who were assessed as being in a persistent vegetative state and those with a severe disability.

\section{Unit of analysis issues}

We paid attention to outcome data collected at more than one time point within a study. For our primary analysis we reported data for the final time point only. In subgroup analyses we considered each time point but could not calculate effect estimates as this would lead to a unit of analysis error.

\section{Dealing with missing data}

We collected data as presented in each study report. We noted participant loss, or other missing data in the Characteristics of included studies and assessed risk of bias on any noted attrition. We used available case data reported by study authors for analysis.

\section{Assessment of heterogeneity}

We assessed evidence of methodological and clinical heterogeneity during the data extraction of each included study report. We assessed statistical heterogeneity by calculation of the $\mathrm{I}^{2}$ statistic. We judged heterogeneity over $60 \%$ to be substantial (Higgins 2011).

As well as consideration of methodological, clinical and statistical heterogeneity, we assessed potential inconsistency by inspection of point estimates and the overlap of confidence intervals (Cls) between studies.

\section{Assessment of reporting biases}

We attempted to source the published protocol of each of our included studies using clinical trial registers. We compared protocols of prospectively registered studies against published study results to assess the risk of selective reporting bias.

We generated a funnel plot to assess the risk of publication bias in the review; an asymmetric funnel plot may indicate potential publication of only positive results (Egger 1997). 


\section{Data synthesis}

We collected event data for each study and used Review Manager (RevMan) to calculate odds ratios to express effect size. The odds ratio was chosen because of the large variation in baseline event data between trials. We calculated $\mathrm{Cls}$ at $95 \%$ and used a $\mathrm{P}$ value of 0.05 or below to judge if a result was statistically significant. We considered whether there was imprecision in the results of analysis by assessing the $\mathrm{Cl}$ around an effects measure; a wide $\mathrm{Cl}$ would suggest a higher level of imprecision in our results, and a small number of studies would also reduce the precision (Guyatt 2011).

\section{Subgroup analysis and investigation of heterogeneity}

We performed subgroup analyses to determine whether the treatment effect varies with: duration of hypothermia; and length of follow up.

\section{Sensitivity analysis}

We explored the potential effects of decisions made as part of the review process as follows.

1. We considered subgroup analysis of mortality and unfavourable outcome for studies that had reported data at more than one time point. We removed data, so that only one of each time points were included. We planned to compare the effect estimates from the sensitivity analysis with the effect estimates from the subgroup analysis. We would have reported any differences that altered interpretation of the results.
2. We excluded all studies that we judged to be at high or unclear risk of selection bias. We planned to compare the effect estimates from the sensitivity analysis with the effect estimates from the main analysis. We would have reported differences that altered interpretation of the results.

\section{RES U L T S}

\section{Description of studies}

\section{Results of the search}

We included an additional nine studies for the 2017 update (Adelson 2013; Andrews 2015; Beca 2015; Clifton 2011; Idris 2014; Lee 2010; Li 2009; Yan 2010; Zhao 2011).

We re-assessed eight studies that had been excluded during a previous update due to insufficient description of methods of sequence generation. We included five of these in this update to ensure consistency across all studies (Chen 2001; Li 2008; Qiu 2005; Wang 2005; Zhi 2003) and excluded three (Meissner 1998; Wang 2007; Yan 2007), see Characteristics of excluded studies.

In total, we included 37 randomised controlled trials (RCTs) (Adelson 2005 HYPO 1; Adelson 2005 HYPO 2; Adelson 2013; Aibiki 2000; Andrews 2015; Beca 2015; Biswas 2002; Chen 2001; Clifton 1992; Clifton 1993; Clifton 2001; Clifton 2011; Harris 2009; Hashiguchi 2003; Hirayama 1994; Hutchison 2008; Idris 2014; Ishikura 1998; Jiang 2000; Lee 2010; Li 2008; Li 2009; Marion 1997; Meissner 2003a; Meissner 2003b; Qiu 2005; Qiu 2007; Shiozaki 1993; Shiozaki 1999; Shiozaki 2001; Smrcka 2005; Wang 2005; Yan 2001; Yan 2010; Zhang 2000; Zhao 2011; Zhi 2003). See Figure 1. 
Figure 1. Study flow diagram.

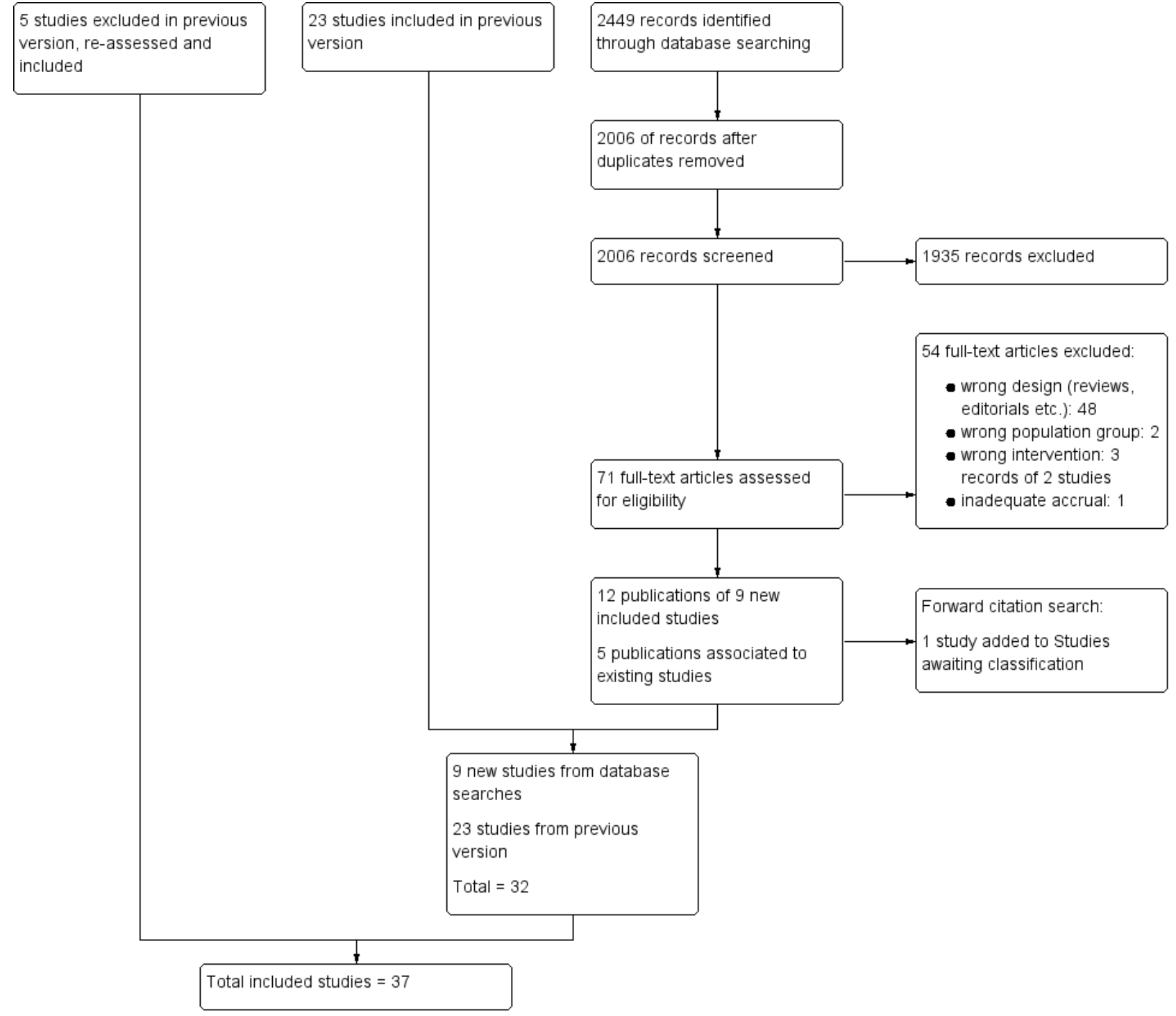

\section{Included studies}

Details of individual studies are presented in Characteristics of included studies.

The 37 included RCTs randomised 3110 participants. Of these, seven studies included only children (Adelson 2005 HYPO 1; Adelson 2005 HYPO 2; Adelson 2013; Beca 2015; Biswas 2002; Hutchison 2008; Li 2009); and 13 included only adult participants (Andrews 2015; Chen 2001; Clifton 1992; Clifton 1993; Clifton 2001; Clifton 2011; Harris 2009; Hirayama 1994; Marion 1997; Meissner 2003b; Qiu 2007; Yan 2010; Zhao 2011). Ten studies included both children and adults (Aibiki 2000; Hashiguchi 2003; Shiozaki 1993; Shiozaki 1999 (participants over 10 years of age); Idris 2014; Lee 2010; Yan 2001 (participants over 12 years of age); Li 2008 (participants over 16 years of age); Shiozaki 2001 (participants from birth); and Qiu 2005 (participants over 14 years of age). Other studies did not specify inclusion of children or adults, although reported mean ages suggested that most participants were adults in studies by Jiang 2000, Smrcka 2005 and Zhi 2003. We could not determine participants' ages in Ishikura 1998, Meissner 2003a, Wang 2005 and Zhang 2000.

We included all studies in which participants had TBI, although we were not always able to determine if injuries were only 'closed'. One study specified inclusion of both 'open' and 'closed' injuries (Harris 2009); most were non-penetrating injuries. Most studies specified that participants were required to have a Glasgow Coma Score (GCS) of eight or less on admission or after resuscitation (Adelson 2005 HYPO 1; Adelson 2005 HYPO 2; Adelson 2013; Aibiki 2000; Biswas 2002; Clifton 1992; Clifton 1993; Clifton 2001; Clifton 2011; Harris 2009; Hashiguchi 2003; Hirayama 1994; Hutchison 2008; Idris 2014; Ishikura 1998; Jiang 2000; Lee 2010; Li 2008; Li 2009; Marion 1997; Qiu 2005; Qiu 2007; Shiozaki 1993; Shiozaki 1999; Shiozaki 2001; Smrcka 2005; Wang 2005; Yan 2001; Yan 2010; Zhang 2000; Zhao 2011; Zhi 2003). Two studies specified a GCS of less than nine (Beca 2015; Meissner 2003b) and one study reported that participants were required to have an average GCS of three to eight (Chen 2001). One study did not specify a GCS as part of inclusion criteria and $34.4 \%$ of their included participants had a score of 
nine or more (Andrews 2015). Participant inclusion criteria were not available for Meissner 2003a.

Most studies specified that hypothermia was commenced immediately or shortly after admission (Adelson 2005 HYPO 1; Adelson 2005 HYPO 2; Adelson 2013; Aibiki 2000; Beca 2015; Biswas 2002; Chen 2001; Clifton 1992; Clifton 1993; Clifton 2001; Clifton 2011; Hirayama 1994; Idris 2014; Jiang 2000; Li 2008; Li 2009; Marion 1997; Meissner 2003a; Meissner 2003b; Shiozaki 1999; Shiozaki 2001; Smrcka 2005; Yan 2001; Yan 2010; Zhao 2011). Both Lee 2010 and Qiu 2007 included participants who required craniotomies as part of treatment and hypothermia was commenced postsurgery in these participants. Qiu 2005 and Zhi 2003 commenced treatment either immediately or delayed if surgery was required. Three studies had an extended time for study inclusion of up to 24 hours post-injury (Adelson 2005 HYPO 2; Qiu 2005; Zhi 2003), Harris 2009 included participants up to 48 hours post-injury and Andrews 2015 included participants who had been injured up to 10 days previously. Hashiguchi 2003 required participants to have stabilized intracranial pressure (ICP) before any intervention. We were unable to determine time of hypothermia treatment in the remaining studies.

Thirty-three studies reported data for our primary outcome of mortality (Adelson 2005 HYPO 1; Adelson 2005 HYPO 2; Adelson 2013; Aibiki 2000; Andrews 2015; Beca 2015; Biswas 2002; Chen 2001; Clifton 1992; Clifton 1993; Clifton 2001; Clifton 2011; Harris 2009; Hashiguchi 2003; Hirayama 1994; Hutchison 2008; Ishikura 1998; Jiang 2000; Lee 2010; Li 2009; Marion 1997; Meissner 2003b; Qiu 2005; Qiu 2007; Shiozaki 1993; Shiozaki 1999; Shiozaki 2001; Smrcka 2005; Yan 2001; Yan 2010; Zhang 2000; Zhao 2011; Zhi 2003). Thirty-one studies reported unfavourable outcomes or which 30 studies used the Glasgow Outcome Scale (GOS) (Adelson 2005 HYPO 1; Adelson 2005 HYPO 2; Adelson 2013; Aibiki 2000; Andrews 2015; Biswas 2002; Chen 2001; Clifton 1992; Clifton 1993; Clifton 2001; Clifton 2011; Harris 2009; Hashiguchi 2003; Hirayama 1994; Hutchison 2008; Idris 2014; Jiang 2000; Lee 2010; Li 2008; Marion 1997; Qiu 2005; Qiu 2007; Shiozaki 1993; Shiozaki 1999; Shiozaki 2001; Smrcka 2005; Wang 2005; Yan 2010; Zhao 2011; Zhi 2003) and one study used a scoring system that was equivalent to the GOS (Beca 2015). Fourteen studies reported data for pneumonia (Adelson 2005 HYPO 1; Adelson 2005 HYPO 2; Adelson 2013; Aibiki 2000; Beca 2015; Clifton 1992; Clifton 1993; Hashiguchi 2003; Hutchison 2008; Idris 2014; Jiang 2000; Shiozaki 1993; Shiozaki 1999; Shiozaki 2001).

We were able to access the full-text of 34 studies. One study (Ishikura 1998) was published only as an abstract but had sufficient data to justify inclusion and one study (Zhang 2000) was published in Chinese; we did not seek translation of Zhang 2000 for this update and the data for this study were taken from the English abstract only.

\section{Excluded studies}

We excluded 53 full-text articles that were identified for further assessment in the 2017 update because they were the wrong study design. We list eight key articles (from the 53 articles), with nine references, in Characteristics of excluded studies (ACTRN12615001119583p; Maekawa 2015; Meissner 1998; NCT01333488 NCT02353793; Rincon 2014; Wang 2007; Yan 2007). Three of these were from clinical trials registers (ACTRN12615001119583p; NCT01333488; NCT02353793) and three were excluded in a previous version of the review but reconsidered for the 2017 update (Meissner 1998; Wang 2007; Yan 2007). Reasons for excluding these studies were assessment of the wrong intervention (ACTRN12615001119583p; Maekawa 2015) and assessment of the wrong participant group (Rincon 2014; NCT02353793). There was insufficient information in Wang 2007 and Yan 2007 to assess eligibility and both appeared to not include relevant outcomes. Meissner 1998 did not appear to be an RCT and NCT01333488 had been terminated early with inadequate accrual. See Figure 1.

\section{Ongoing studies}

We identified two RCTs that are ongoing (Lei 2015; Nichol 2015). Both studies are recruiting adult participants with severe brain injury to receive hypothermia or normothermia treatment. Details are presented in Characteristics of ongoing studies.

\section{Studies awaiting classification}

We have included two studies awaiting classification. We identified one study during forward citation tracking (Gál 2012). We were unable to establish if this abstract was a later publication of Smrcka 2005 or an additional new study. We have not included Gál 2012 in this update; and we have written to the study authors for more information. We identified one study in the pre-publication search in June 2017 (Tang 2017). We will incorporate this study into the review in a future update, as appropriate. See Characteristics of studies awaiting classification.

\section{Risk of bias in included studies}

We assessed each of the following domains and presented a summary of the risk of bias assessments and a 'Risk of bias' graph. Assessments of performance bias and detection bias were made by reported outcome, with blank spaces indicating that the outcome was not reported by study authors. See Characteristics of included studies and Figure 2 and Figure 3. 
Figure 2. Risk of bias graph: review authors' judgements about each risk of bias item presented as percentages across all 37 included studies.

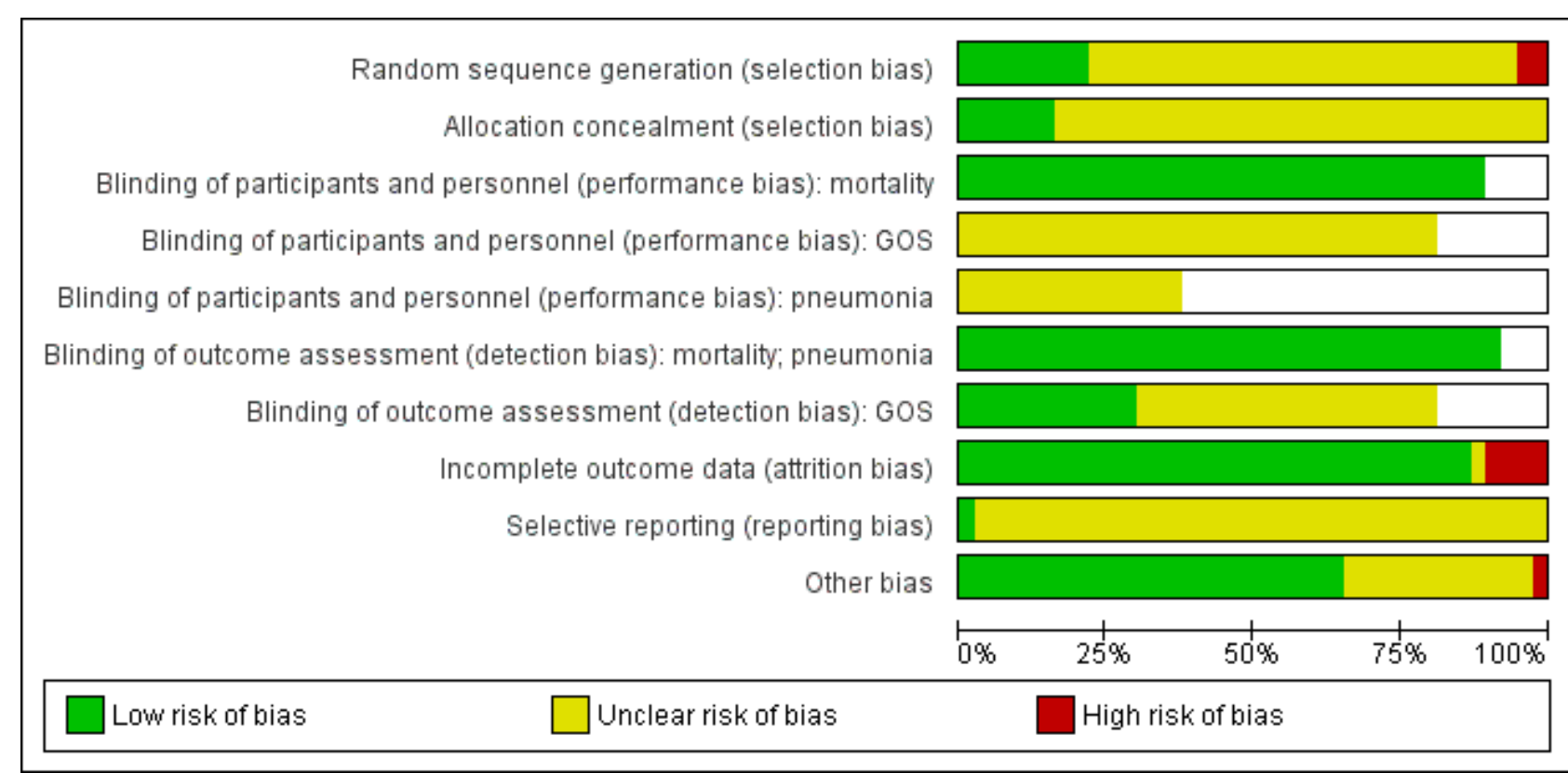


Figure 3. Risk of bias summary: review authors' judgements about each risk of bias item for each included study. Note: blank spaces in risk of bias table indicate that the relevant outcome was not reported by study authors

\begin{tabular}{|c|c|c|c|c|c|c|c|c|c|c|}
\hline &  & 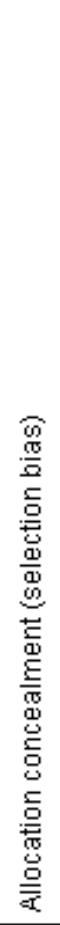 & 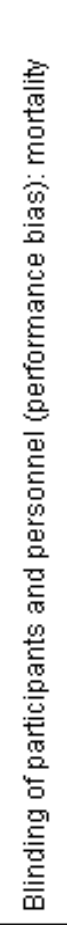 & 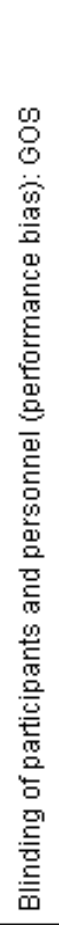 & 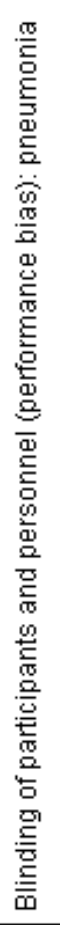 & 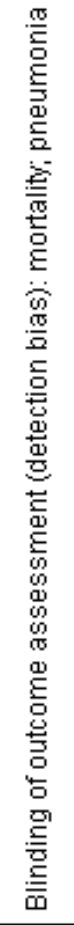 & 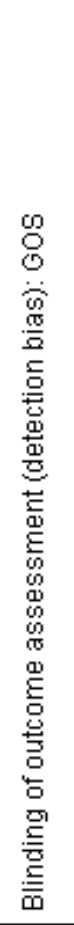 & 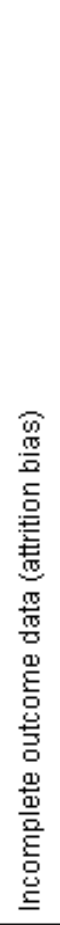 & 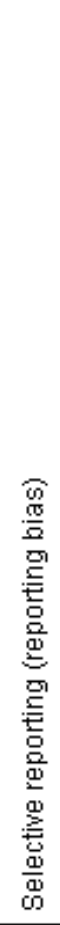 & 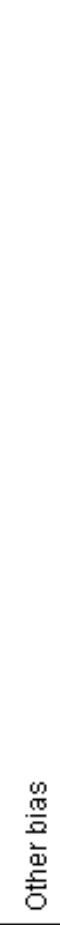 \\
\hline Adelson 2005 HYPO 1 & $?$ & $?$ & $\odot$ & $?$ & $?$ & $\odot$ & $\odot$ & $\odot$ & $?$ & + \\
\hline Adelson 2005 HYPO 2 & $?$ & $?$ & $\odot$ & $?$ & $?$ & $\odot$ & $\odot$ & $\odot$ & $?$ & $\odot$ \\
\hline Adelson 2013 & + & + & + & $?$ & $?$ & + & + & 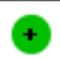 & $?$ & + \\
\hline Aibiki 2000 & $?$ & $?$ & $\odot$ & $?$ & $?$ & 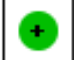 & $?$ & $?$ & $?$ & + \\
\hline Andrews 2015 & + & + & + & $?$ & & 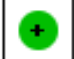 & + & 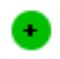 & $?$ & 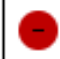 \\
\hline Beca 2015 & $\oplus$ & $\oplus$ & $\odot$ & $?$ & $?$ & $\odot$ & $?$ & $\odot$ & + & 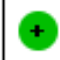 \\
\hline Biswas 2002 & $?$ & $?$ & $\odot$ & $?$ & & $\bullet$ & $\odot$ & $\odot$ & $?$ & $?$ \\
\hline Chen 2001 & $?$ & $?$ & $\odot$ & & & 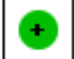 & & 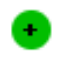 & $?$ & $?$ \\
\hline Clifton 1992 & $?$ & $?$ & + & $?$ & $?$ & + & $?$ & 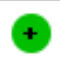 & $?$ & + \\
\hline Clifton 1993 & $?$ & $?$ & $\odot$ & $?$ & $?$ & + & + & 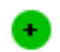 & $?$ & + \\
\hline Clifton 2001 & $?$ & $?$ & $\odot$ & $?$ & & 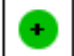 & + & $\odot$ & $?$ & + \\
\hline Clifton 2011 & $\oplus$ & $\oplus$ & + & $?$ & & + & + & + & $?$ & $?$ \\
\hline Harris 2009 & $\oplus$ & $?$ & + & $?$ & & + & $?$ & $\odot$ & $?$ & $?$ \\
\hline Hashiguchi 2003 & $?$ & $?$ & + & $?$ & $?$ & + & $?$ & + & $?$ & + \\
\hline Hirayama 1994 & $?$ & $?$ & $\odot$ & $?$ & & 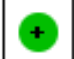 & $?$ & $\odot$ & $?$ & + \\
\hline Hutchison 2008 & + & $\oplus$ & + & $?$ & $?$ & + & + & $\odot$ & $?$ & $?$ \\
\hline Idris 2014 & $?$ & $?$ & & $?$ & $?$ & + & $?$ & $\odot$ & $?$ & $?$ \\
\hline$\therefore$ & 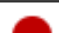 & $?$ & $=$ & & & & & ? & 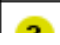 & \\
\hline
\end{tabular}


Figure 3. (Continued)

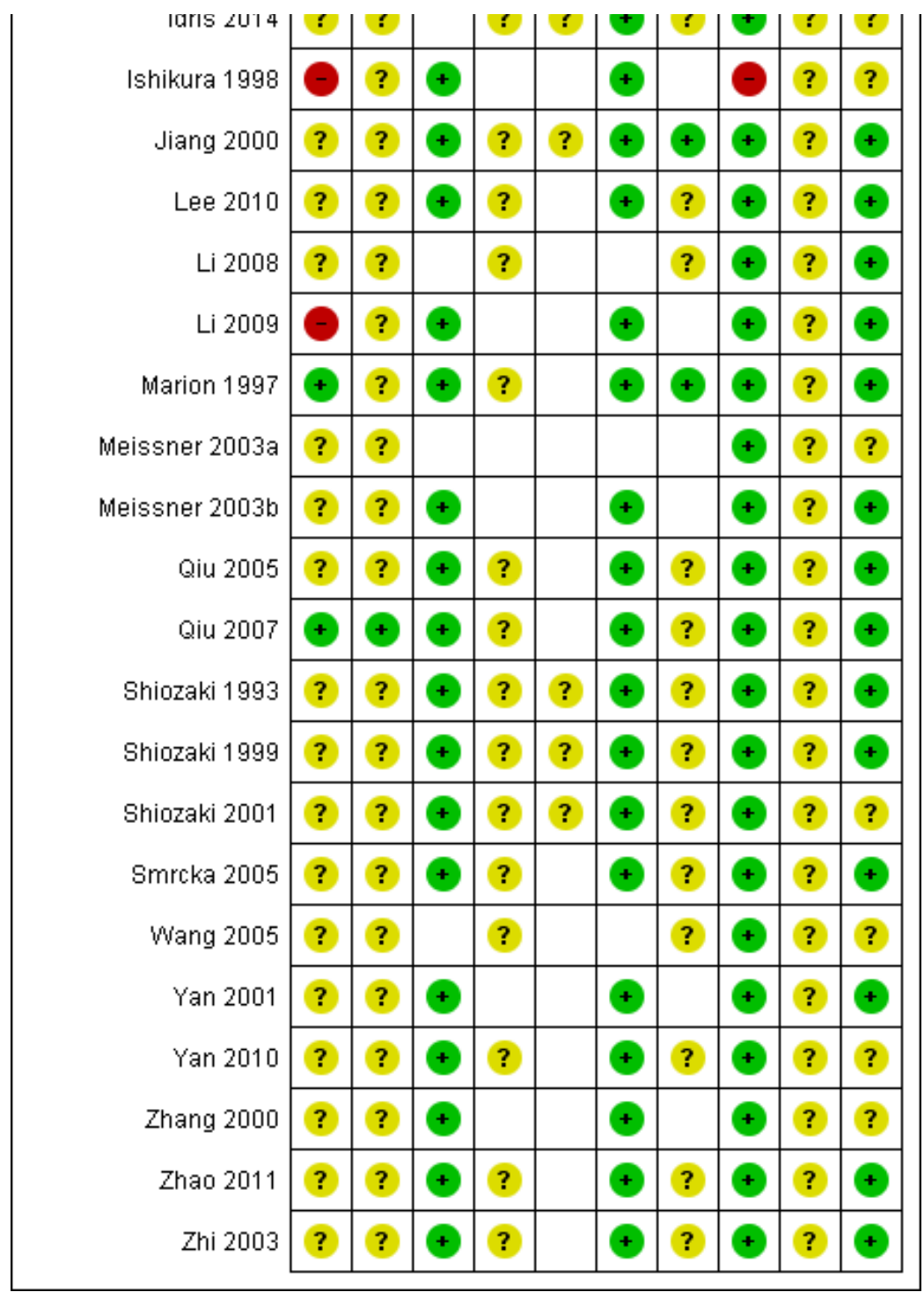

\section{Allocation}

Eight trials had adequately described an appropriate method of randomisation (Adelson 2013; Andrews 2015; Beca 2015; Clifton 2011; Harris 2009; Hutchison 2008; Marion 1997; Qiu 2007). Ishikura 1998 had insufficient details in the abstract on randomisation but the number of participants in each group was uneven and we suspected an inadequate method of randomisation. Li 2009 had randomised participants on the basis of date of admission which introduced risk of bias. We therefore judged Ishikura 1998 and $\mathrm{Li}$ 2009 to have high risk of bias. All other studies provided insufficient detail and risk of bias was unclear.

We judged only six studies to have adequately described a method of concealing the sequence generation from attending investigators or personnel (Adelson 2013; Andrews 2015; Beca 2015; Clifton 2011; Hutchison 2008; Qiu 2007). All other studies had either reported insufficient detail or had not reported methods of allocation concealment.

\section{Blinding}

It was not possible to blind personnel or awake participants from the intervention. For mortality, we decided that this lack of blinding would not introduce any performance bias and therefore judged all studies that reported mortality to have low risk of performance bias (Adelson 2005 HYPO 1; Adelson 2005 HYPO 2; Adelson 2013; Aibiki 2000; Andrews 2015; Beca 2015; Biswas 2002; Chen 2001; Clifton 1992; Clifton 1993; Clifton 2001; Clifton 2011; Harris 2009; Hashiguchi 2003; Hirayama 1994; Hutchison 2008; Ishikura 1998; Jiang 2000; Lee 2010; Li 2009; Marion 1997; Meissner 2003b; Qiu 2005; Qiu 2007; Shiozaki 1993; Shiozaki 1999; Shiozaki 2001; Smrcka 2005; Yan 2001; Yan 2010; Zhang 2000; Zhao 2011; Zhi 2003). However, we could not ascertain whether there were increased risks of performance bias for other outcomes and we therefore recorded studies that reported data for pneumonia and unfavourable outcomes as unclear for performance bias.

We did not think that inability to blind outcome assessors would influence the reporting and assessment of mortality or pneumonia, 
and we therefore judged all studies that reported these outcomes to have low risk of detection bias (Adelson 2005 HYPO 1; Adelson 2005 HYPO 2; Adelson 2013; Aibiki 2000; Andrews 2015; Beca 2015; Biswas 2002; Chen 2001; Clifton 1992; Clifton 1993; Clifton 2001; Clifton 2011; Harris 2009; Hashiguchi 2003; Hirayama 1994; Hutchison 2008; Idris 2014; Ishikura 1998; Jiang 2000; Lee 2010; Li 2009; Marion 1997; Meissner 2003b; Qiu 2005; Qiu 2007; Shiozaki 1993; Shiozaki 1999; Shiozaki 2001; Smrcka 2005; Yan 2001; Yan 2010; Zhang 2000; Zhao 2011; Zhi 2003). However, assessment of unfavourable outcomes could be influenced by knowledge of group allocation and we therefore judged detection bias based on information presented in the relevant papers. Eleven studies had reported that investigators assessing unfavourable outcomes had been blinded and we judged these to have low risk of detection bias (Adelson 2005 HYPO 1; Adelson 2005 HYPO 2; Adelson 2013; Andrews 2015; Biswas 2002; Clifton 1993; Clifton 2001; Hutchison 2008; Jiang 2000; Marion 1997; Zhao 2011). The remaining studies did not provide information about any attempts to reduce detection bias for this outcome and we therefore recorded an unclear judgement for these studies.

\section{Incomplete outcome data}

We judged 31 studies to have low risk of attrition bias (Adelson 2005 HYPO 1; Adelson 2005 HYPO 2; Adelson 2013; Andrews 2015; Biswas 2002; Chen 2001; Clifton 1992; Clifton 1993; Clifton 2001; Clifton 2011; Hashiguchi 2003; Hirayama 1994; Idris 2014; Jiang 2000; Lee 2010; Li 2008; Li 2009; Marion 1997; Meissner 2003b; Qiu 2005; Qiu 2007; Shiozaki 1993; Shiozaki 1999; Shiozaki 2001; Smrcka 2005; Wang 2005; Yan 2001; Yan 2010; Zhang 2000; Zhao 2011; Zhi 2003). These studies had either reported no losses or had reported a small number of losses with explanations. We judged four studies to have high risk of attrition bias (Beca 2015; Harris 2009; Hutchison 2008; Ishikura 1998) with a large percentage of losses or losses unevenly spread between groups. We had insufficient information on attrition in two studies and recorded an unclear judgement for these (Aibiki 2000; Meissner 2003a).

\section{Selective reporting}

Only four studies reported details of clinical trial registration and were prospectively registered (Adelson 2013; Andrews 2015; Beca 2015; Clifton 2011). We judged the reported outcomes in Beca 2015 to be comparable to those listed in the protocol and therefore judged this study to have low risk of reporting bias. However, there were some inconsistencies between the clinical trial register documents and the study reports in Adelson 2013, Andrews 2015 and Clifton 2011 and we were unable to assess whether there was risk of reporting bias in these studies. One study (Hutchison 2008) had provided a clinical trials registration number but this was a retrospective registration and therefore did not facilitate judgment of reporting bias. We were unable to identify trial registration, prospective or retrospective, of any of the remaining 32 included studies and therefore recorded an unclear judgement for reporting bias.

\section{Other potential sources of bias}

We did not identify any additional sources of bias in 24 studies (Adelson 2005 HYPO 1; Adelson 2005 HYPO 2; Adelson 2013; Aibiki 2000; Beca 2015; Clifton 1992; Clifton 1993; Clifton 2001; Hashiguchi 2003; Hirayama 1994; Jiang 2000; Lee 2010; Li 2008; Li 2009; Marion 1997; Meissner 2003b; Qiu 2005; Qiu 2007; Shiozaki 1993; Shiozaki 1999; Smrcka 2005; Yan 2001; Zhao 2011; Zhi 2003) and judged these to have low risk of additional bias. Eleven studies reported some imbalances in baseline characteristics and we were unable to judge how this might influence the results or we had insufficient information on baseline characteristics, or study details, to assess the risk of bias; we recorded an unclear judgement for these (Biswas 2002; Chen 2001; Clifton 2011; Harris 2009; Hutchison 2008; Idris 2014; Ishikura 1998; Meissner 2003a; Wang 2005; Yan 2010; Zhang 2000). One study (Shiozaki 2001) reported that method of temperature management was at the discretion of the physician and we did not know whether this may influence outcome results; we recorded this as unclear risk of bias. One study made a change to the inclusion criteria part way through the trial to include participants up to 10 days after injury (Andrews 2015); this had the potential to introduce bias into the results and therefore we judged this to be high risk of bias.

\section{Effects of interventions}

See: Summary of findings for the main comparison Hypothermia for traumatic brain injury

\section{Primary outcomes}

\section{Mortality at end of follow-up}

We included 33 studies, with 2988 participants, that reported mortality.

Mortality is contained within assessment of the Glasgow Outcome Scale (GOS) and therefore overlaps with our second outcome (i.e. unfavourable outcome). We collected data from studies that reported mortality separately as part of the GOS data. Reported time points for this outcome varied: within hospital (Marion 1997); at 22 days (Shiozaki 2001); at 28 days (Andrews 2015; Harris 2009); at one month (Adelson 2005 HYPO 1; Adelson 2005 HYPO 2; Biswas 2002; Clifton 1993; Hirayama 1994; Li 2009; Meissner 2003b; Yan 2001; Zhang 2000), three months (Adelson 2013; Biswas 2002; Clifton 1992; Marion 1997; Shiozaki 2001; Zhao 2011), six months (Aibiki 2000; Andrews 2015; Biswas 2002; Chen 2001; Clifton 2001; Clifton 2011; Hashiguchi 2003; Hutchison 2008; Lee 2010; Marion 1997; Shiozaki 1993; Shiozaki 1999; Smrcka 2005; Zhi 2003), and 12 months (Beca 2015; Biswas 2002; Jiang 2000; Marion 1997; Qiu 2007); at two years follow-up (Qiu 2005); and at an unclearlyreported time point up to seven years (Yan 2010). Some studies reported mortality at more than one time point; we only collected data for the latest time point, which represented end of followup. We did not collect data for Ishikura 1998 as it was unclearly reported.

We identified inconsistencies in our visual inspection of results with differences in direction of effect between studies. We did not perform meta-analysis. Individual study data are reported in Analysis 1.1. There were few studies with low risk of bias for sequence generation and allocation concealment. We were also concerned that some studies, for example Andrews 2015, had differences in study design leading to some excessive diversity that made pooling unwise. Using GRADE, we downgraded the evidence for mortality to very low quality, see Summary of findings for the main comparison.

\section{Unfavourable outcome at final follow-up}

We included 31 studies, with 2869 participants, that reported unfavourable outcome. Assessments were made at one, three, six and 12 months and at two years follow-up. Some studies reported 
unfavourable outcome at more than one time point; we only collected data for the final time point, which represented end of follow-up. We did not collect data for Adelson 2005 HYPO 1, Adelson 2005 HYPO 2, Chen 2001 and Harris 2009 which were not reported as event data.

We identified inconsistencies from visual inspection of results and there was a substantial level of statistical heterogeneity $\left(I^{2}=66 \%\right)$. Therefore, we did not perform meta-analysis. Individual study data are reported in Analysis 1.2. There were few studies with low risk of bias for sequence generation and allocation concealment. We were also concerned that some studies, for example Andrews 2015, had differences in study design leading to some excessive diversity that made pooling unwise. Using GRADE, we downgraded the evidence for unfavourable outcome to very low quality, see Summary of findings for the main comparison.

\section{Secondary outcomes}

\section{Frequency of pneumonia}

We included 14 studies, with 768 participants, that reported pneumonia. It was not possible to collect data for Adelson 2005 HYPO 1 and Adelson 2005 HYPO 2 because the data for pneumonia were combined with other complications. We identified inconsistencies in visual inspection of results and did not pool data for meta-analysis. Individual study data are reported in Analysis 1.3. There were few studies with low risk of bias for sequence generation and allocation concealment and we used GRADEpro GDT 2015 to downgrade the evidence for pneumonia to low quality, see Summary of findings for the main comparison.

\section{Subgroup analysis}

\section{Duration of hypothermia}

Four studies described therapeutic cooling for 24 hours (Clifton 1992; Harris 2009; Hutchison 2008; Marion 1997) and 28 studies described cooling for more than 24 hours (Adelson 2005 HYPO 1; Adelson 2005 HYPO 2; Adelson 2013; Aibiki 2000; Andrews 2015; Beca 2015; Biswas 2002; Chen 2001; Clifton 1993; Clifton 2001; Clifton 2011; Hashiguchi 2003; Hirayama 1994; Jiang 2000; Lee 2010; Li 2009; Meissner 2003a; Meissner 2003b; Qiu 2005; Qiu 2007; Shiozaki 1993; Shiozaki 1999; Shiozaki 2001; Smrcka 2005; Yan 2001; Yan 2010; Zhang 2000; Zhao 2011). One study (Idris 2014) reported duration of intervention of at least 24 hours and we included this study in the 'more than 24 hours' subgroup. We did not have relevant information for Ishikura 1998 or Li 2008 and could not include these studies in subgroup analyses for any outcomes.

We remained concerned about differences identified in the visual inspection of the results of our included studies and therefore did not perform pooled subgroup analysis for each outcome. Also, we were concerned about the unclear risk of bias for most studies. Individual study data are reported in Analysis 2.1, Analysis 2.2, and Analysis 2.3.

\section{Length of follow-up}

Studies reported mortality at four different time points. Three time points were clearly dictated by measurements on the GOS assessment; the fourth time point was stated or assumed to be within the initial study period (assumed to be within 28 days). Qiu 2005 reported follow-up at two years which we combined with data measured at 12 months. The time point was unclearly reported in Chen 2001 but we assumed it was six months from other information in the study report. The four subgroups for mortality were: one, three, six and 12 months or more; and for unfavourable outcome were: three, six and 12 months or more (with no event data for one month). However, as some studies reported outcome data at more than one time point, it was not appropriate to complete statistical tests of subgroup interactions. Visual inspection of the data for mortality when separated by length of follow-up suggested there were no differences between groups at one, three and six months. We noted differences between groups at 12 months or more but we could not explain this and we remained concerned about unclear risk of bias across most studies included in the subgroup analysis and inconsistencies from visual inspection of the data. See Analysis 3.1.

Similarly, it was not appropriate to carry out statistical tests for length of follow-up subgroups for unfavourable outcome. Visual inspection of the data showed some differences between groups, with fewer unfavourable outcomes at three months and 12 months but not at six months. Again, we remained concerned about risks of bias across studies and unexplained heterogeneity that may have influenced this result. See Analysis 3.2.

\section{Sensitivity analysis}

The subgroup analysis data divided by length of follow-up time presented more meaningful results overall but as these analyses included data from more than one study the overall effect estimates could not be calculated without including a unit-of-analysis error.

In sensitivity analyses, we removed studies that had been included at more than one time point so that data were recorded at one time point only. Therefore in Analysis 3.1, in which study data were recorded for mortality, we assessed the impact of removing data for Andrews 2015, Biswas 2002, Marion 1997 and Shiozaki 2001 at each time point. We remained concerned about differences in direction of results and did not calculate effect estimates in metaanalysis. Simlarly, we considered the impact of removing data for Biswas 2002 at each time point for unfavourable outcome but did not calculate effect estimates owing to differences in the remaining studies.

We removed studies that had an unclear or high risk of selection bias, therefore we collected data for eight possible studies for our primary outcomes (Adelson 2013; Andrews 2015; Beca 2015; Clifton 2011; Harris 2009; Hutchison 2008; Marion 1997; Qiu 2007). There remained apparent differences between the study results that did not justify calculation of a pooled effect estimate. We did not consider the impact of other types of bias in these eight studies or in the remaining studies in a sensitivity analysis.

\section{DISCUSSION}

\section{Summary of main results}

We included 37 studies that assessed the effect of hypothermia on participants with TBI.

We identified inconsistencies from visual inspection of the results of our included studies and did not perform meta-analysis for review outcomes. Studies showed differences in the direction of effect and attempts to explore this through subgroup analysis by duration of hypothermia and length of follow-up, and sensitivity analysis by assessment of risk of bias, did not explain these differences. We 
used GRADEpro GDT 2015 to downgrade the evidence for each of our outcomes by one level for inconsistency.

\section{Overall completeness and applicability of evidence}

We completed a thorough search for the 2017 update of this review, carrying out both backward and forward citation tracking of included studies. We used the search strategies delineated in a previous version of this review (Sydenham 2009b). All 37 studies included in the review provided evidence applicable to patients who have sustained a closed TBI and who had been treated with a method to induce hypothermia after injury. Most studies initiated treatment immediately after injury, although some studies commenced treatment within 24 hours or 48 hours and one study included participants who had received a brain injury within 10 days (Andrews 2015). Andrews 2015 also included some participants who had been assessed with a Glasgow Coma Score of nine or above on admission. This introduced an element of indirectness into the results and we used GRADEpro GDT 2015 to downgrade the evidence by one level.

It is possible that inconsistencies that we identified in the results may be explained by the differences in participants between included studies and we did not explore this during subgroup or sensitivity analysis. For example, we did not attempt to analyse data according to age of participants and we included data for adults and children within the same analyses, and we did not explore differences that may relate to the cause or type of injury. Our review considered outcome data for mortality, poor outcome, and pneumonia; we did not consider additional outcome data such as quality of life or potential adverse effects such as coagulation abnormalities, myocardial ischaemia or atrial fibrillation. We propose that future review updates include additional outcomes, and appropriate additional subgroup analyses to explore differences between study participants, for completeness of evidence.

\section{Quality of the evidence}

Only eight studies adequately described methods of randomisation. We accepted that it was not feasible to blind personnel to the intervention in these studies, however detection bias could have been minimized by blinding of outcome assessors, particularly for the assessment of unfavourable outcome. Few studies had described this adequately. We were unable to assess the risk of selective reporting bias in 33 of the studies due to lack of prospective trial registration and we identified baseline imbalances in some studies and it was not clear if these imbalances could have influenced results. One study (Andrews 2015) had reported an important change to the inclusion criteria part way through the study, increasing the potential length of time after brain injury from 72 hours to 10 days and the trial was stopped early because of apparent harm, which may introduce bias. We used GRADEpro GDT 2015 in our assessment of study limitations to downgrade the evidence by a further level. Overall, we judged the quality of the evidence for mortality and unfavourable outcome as very low and the quality of the evidence for pneumonia as low.

Again, it is possible that inconsistencies that we identified in the results may be explained by issues of quality in our included studies and we did not explore this in detail during sensitivity analysis.

\section{Potential biases in the review process}

We are confident that we identified eligible studies for this update using a thorough search strategy which was not limited by language, date of publication or publication status. We reconsidered studies during the 2017 update which had been previously excluded owing to lack of detail on randomisation methods which led to inclusion of a further five studies. However, we did not seek translation of one of these studies (Zhang 2000) and our assessment of study methodology and risk of bias for this study was therefore limited.

We did not carry out a grey literature search, nor contact authors in the field to identify any unpublished studies, although visual analysis of a funnel plot did not suggest any particular risk of publication bias (Figure 4). We did not seek additional information from study authors regarding their study protocols, methods and results to clarify risk of bias, and we judged all studies equally on the information provided in the full report. 
Figure 4. Funnel plot of comparison 1: Therapeutic cooling versus no cooling, outcome: 1.1 Mortality.

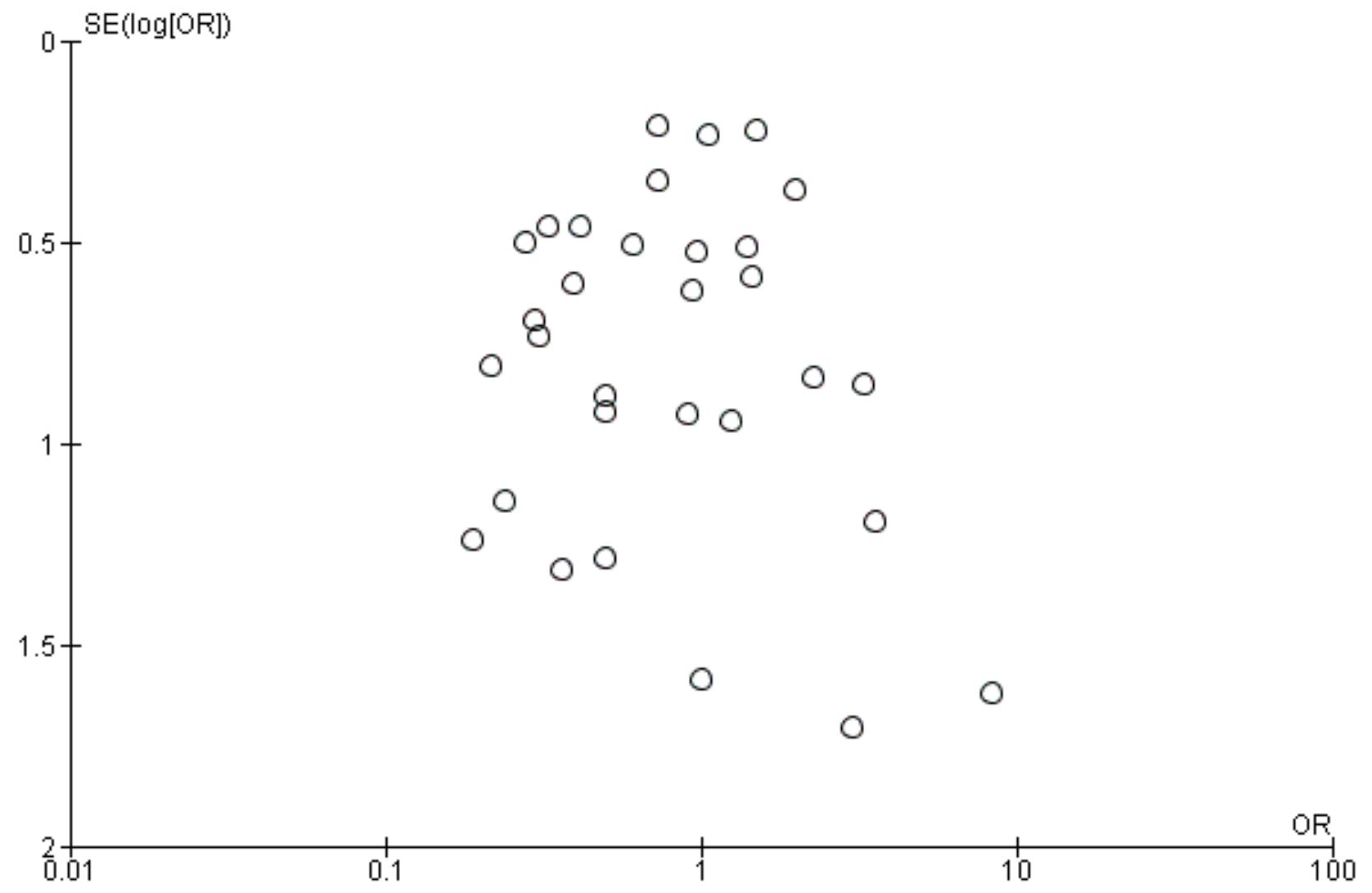

\section{Agreements and disagreements with other studies or reviews}

Systematic reviews by Crossley 2014 and Georgiou 2013 both confirm low quality evidence in this field. Both reviews show evidence of a reduction in mortality and poor outcome when hypothermia is induced. However, both reviews included fewer studies than this Cochrane Review and did not include more recent studies published since 2012. Georgiou 2013 included analysis of only higher quality studies demonstrating no evidence of an effect of hypothermia on mortality or unfavourable outcome.

\section{AUTHORS' CONCLUSIONS}

\section{Implications for practice}

There remains insufficient evidence to be certain of whether hypothermia is beneficial in the treatment of people with traumatic brain injury (TBI). We are aware of two ongoing studies that may add data to the existing study results and address this uncertainty.

\section{Implications for research}

More high quality randomised controlled trials are needed to determine the benefit of hypothermia for TBI.

\section{ACKNOWLEDGEMENTS}

Thanks to:

- Brenda Thomas (Cochrane Stroke) for help and advice with the original Embase search strategy.

- Ian Whittle, Kate Signorini, Elena Telaro, Yoichi Nagayama, Irene Kwan, Frank Del Vecchio, Lisa Xue and Cynthia To for help with manuscripts in languages other than English.

- Reinhard Wentz and Irene Kwan of Cochrane Injuries for the original searches.

- Katharine Ker of Cochrane Injuries for work on previous versions of the review.

- Karen Blackhall, Information Specialist of Cochrane Injuries for updating the searches in 2003, 2005, 2008 and 2009.

- Odette Harris and Monique Surles for providing additional data for the Harris 2009 trial. 


\section{R E F E R E N C E S}

\section{References to studies included in this review}

Adelson 2005 HYPO 1 \{published data only\}

* Adelson PD, Ragheb J, Kanev P, Brockmeyer D, Beers SR, Brown SD, et al. Phase II clinical trial of moderate hypothermia after severe traumatic brain injury in children. Neurosurgery 2005;56(4):740-54. [PUBMED: 15792513]

Bayir H, Adelson PD, Wisniewski SR, Shore P, Lai YC, Brown D, et al. Therapeutic hypothermia preserves antioxidant defenses after severe traumatic brain injury in infants and children. Critical Care Medicine 2009;37(2):689-95.

Salonia R, Empey PE, Poloyac SM, Wisniewski SR, Klamerus M, Ozawa, $\mathrm{H}$, et al. Endothelin-1 is increased in cerebrospinal fluid and associated with unfavorable outcomes in children after severe traumatic brain injury. Journal of Neurotrauma 2010;27(10):1819-25. [PUBMED: 20684675]

Su E, Bell MJ, Wisniewski SR, Adelson PD, Janesko-Feldman KL, Salonia $\mathrm{R}$, et al. alpha-synuclein levels are elevated in cerebrospinal fluid following traumatic brain injury in infants and children: the effect of therapeutic hypothermia. Developmental Neuroscience 2010;32(5-6):385-95. [PUBMED: 21124000]

\section{Adelson 2005 HYPO 2 \{published data only\}}

Adelson PD, Ragheb J, Muizelaar JP, Kanev P, Brockmeyer D, Beers $\mathrm{S}$, et al. Phase II clinical trial of moderate hypothermia after severe traumatic brain injury in children. Neurosurgery 2005;56(4):740-54. [PUBMED: 15792513]

\section{Adelson 2013 \{published data only\}}

* Adelson PD, Wisniewski SR, Beca J, Brown SD, Bell M, Muizelaar JP, et al. Comparison of hypothermia and normothermia after severe traumatic brain injury in children (Cool Kids): a phase 3, randomised controlled trial. Lancet Neurology 2013;12(6):546-53. [PUBMED: 23664370]

Empey PE, Velez de Mendizabal N, Bell MJ, Bies RR, Anderson KB, Kochanek PM, et al. Therapeutic hypothermia decreases phenytoin elimination in children with traumatic brain injury. Critical Care Medicine 2013;41(10):2379-87. [PUBMED: 23896831]

\section{Aibiki 2000 \{published data only\}}

Aibiki M, Maekawa S, Yokono S. Moderate hypothermia improves imbalances of thromboxane $\mathrm{A} 2$ and prostaglandin 12 production after traumatic brain injury in humans. Critical Care Medicine 2000;28(12):3902-6. [PUBMED: 11153633]

\section{Andrews 2015 \{published data only\}}

Andrews PJ, Sinclair HL, Rodriguez A, Harris BA, Battison CG, Rhodes JK, et al. Hypothermia for intracranial hypertension after traumatic brain injury. New England Journal of Medicine 2015; Vol. 373, issue 25:2403-12. [10.1056/NEJMoa1507581 [doi]]
Beca 2015 \{published data only\}

Beca J, McSharry B, Erickson S, Yung M, Schibler A, Slater A, et al. Hypothermia for traumatic brain injury in children - a phase II randomised controlled trial. Critical Care Medicine 2015;43(7):1458-66. [DOI: 10.1097/CCM.0000000000000947]

\section{Biswas 2002 \{published data only\}}

Biswas AK, Bruce DA, Sklar FH, Bokovoy JL, Sommerauer JF. Treatment of acute traumatic brain injury in children with moderate hypothermia improves intracranial hypertension. Critical Care Medicine 2002;30(12):2742-51. [PUBMED: 12483067]

\section{Chen 2001 \{published data only\}}

Chen L, Piao Y, Zeng F, Lu M, Kuang Y. Moderate hypothermia therapy for patients with severe head injury. Chinese Journal of Traumatology 2001;4(3):164-7.

\section{Clifton 1992 \{published data only\}}

Clifton GL, Allen S, Berry J, Koch SM. Systemic hypothermia in treatment of brain injury. Journal of Neurotrauma 1992;9(Suppl 2):S487-95. [PUBMED: 1613808]

\section{Clifton 1993 \{published data only\}}

Clifton GL. Hypothermia and hyperbaric oxygen as treatment modalities for severe head injury. New Horizons 1995;3(3):474-8.

Clifton GL. Hypothermia in the management of patients with head injury. Second International Neurotrauma Symposium; 1993 July 4-9; Glasgow. International Neurotrauma Society, 1993.

Clifton GL. Systemic hypothermia in treatment of severe brain injury. Journal of Neurosurgical Anesthesiology 1995;7(2):152-6. [PUBMED: 7772970]

Clifton GL. Systemic hypothermia in treatment of severe brain injury: a review and update. Journal of Neurotrauma 1995;12(5):923-7. [PUBMED: 8594221]

* Clifton GL, Allen S, Barrodale P, Plenger P, Berry J, Koch S, et al. A phase II study of moderate hypothermia in severe brain injury. Journal of Neurotrauma 1993;10(3):263-71. [PUBMED: 8258839]

\section{Clifton 2001 \{published data only\}}

Clifton GL. Hypothermia in neurotrauma. Third International Neurotrauma Symposium; 1995 July 22-27; Toronto, Canada. International Neurotrauma Society, 1995.

* Clifton GL, Miller ER, Choi SC, Levin HS, McCauley S, Smith KR Jr, et al. Lack of effect of induction of hypothermia after acute brain injury. New England Journal of Medicine 2001;344(8):556-63. [PUBMED: 11207351]

\section{Clifton 2011 \{published data only\}}

Clifton GL, Coffey CS, Fourwinds S, Zygun D, Valadka A, Smith KR Jr, et al. Early induction of hypothermia for evacuated intracranial hematomas: a post hoc analysis of two clinical trials. Journal of Neurosurgery 2012;117(4):714-20. [PUBMED: 22839656] 
Clifton GL, Drever P, Valadka A, Zygun D, Okonkwo D. Multicenter trial of early hypothermia in severe brain injury. Journal of Neurotrauma 2009;26(3):393-7. [PUBMED: 19245306]

* Clifton GL, Valadka A, Zygun D, Coffey CS, Drever P, Fourwinds $S$, et al. Very early hypothermia induction in patients with severe brain injury (the National Acute Brain Injury Study: Hypothermia II): a randomised trial. Lancet Neurology 2011;10(2):131-9. [PUBMED: 21169065]

\section{Harris 2009 \{published data only\}}

Harris OA, Muh CR, Surles MC, Pan Y, Rozycki G, Macleod J, et al. Discrete cerebral hypothermia in the management of traumatic brain injury: a randomised controlled trial. Journal of Neurosurgery 2009;110(6):1256-64. [PUBMED: 19249933]

\section{Hashiguchi 2003 \{published data only\}}

Hashiguchi N, Shiozaki T, Ogura H, Tanaka H, Koh T, Noborio M, et al. Mild hypothermia reduces expression of heat shock protein 60 in leukocytes from severely head-injured patients. Journal of Trauma 2003;55(6):1054-60. [PUBMED: 14676650]

\section{Hirayama 1994 \{published data only\}}

Hayashi N, Hirayama T, Udagawa A, Daimon W, Ohata M. Systemic management of cerebral edema based on a new concept in severe head injury patients. Acta Neurochirurgica. Supplementum 1994;60:541-3.

Hayashi N, Shibuya T, Kinoshita K, Jo S, Azuhata T, Mera K, et al. The cerebral thermal dysregulation and hypothermia treatment in severe brain injury patients. Tenth International Symposium on Intracranial Pressure and Neuromonitoring in Brain Injury. 1997: May 25-29; Williamsburg USA. 1997.

* Hirayama T, Katayama Y, Kano T, Hayashi N, Tsubokawa T. Impact of Moderate Hypothermia on Therapies for Intracranial Pressure Control in Severe Traumatic Brain Injury. Nagai H, Ishii S, Maeda M editor(s). Intracranial Pressure IX. Tokyo: SpringerVerlag, 1994:233-6.

Hirayama T, Katayama Y, Maeda T, Kawamata T, Tsubokawa T. Effects of moderate hypothermia on the evolution of cerebral contusion. Third International Neurotrauma Symposium; 1995 July 22-27; Toronto Canada. International Neurotrauma Society, 1995.

\section{Hutchison 2008 \{published data only\}}

Bourdages M, Bigras JL, Farrell CA, Hutchison JS, Lacroix J. Canadian Critical Care Trials Group. Cardiac arrhythmias associated with severe traumatic brain injury and hypothermia therapy. Pediatric Critical Care Medicine 2010;11(3):408-14. [PUBMED: 20464781]

Hutchison JS, Frndova H, Lo TY, Guerguerian AM. Hypothermia Pediatric Head Injury Trial Investigators, Canadian Critical Care Trials Group. Impact of hypotension and low cerebral perfusion pressure on outcomes in children treated with hypothermia therapy following severe traumatic brain injury: a post hoc analysis of the Hypothermia Pediatric Head Injury Trial. Developmental Neuroscience 2010;32(5-6):406-12. [PUBMED: 21252486]
* Hutchison JS, Ward RE, Lacroix J, Hebert PC, Barnes MA, Bohn DJ, et al. Hypothermia therapy after traumatic brain injury in children. New England Journal of Medicine 2008;358(23):2447-56. [PUBMED: 18525042]

\section{Idris 2014 \{published data only\}}

Idris Z, Zenian MS, Muzaimi M, Hamid WZ. Better Glasgow outcome score, cerebral perfusion pressure and focal brain oxygenation in severely traumatized brain following direct regional brain hypothermia therapy: A prospective randomised study. Asian Journal of Neurosurgery 2014;9(3):115-23.

[PUBMED: 25685201]

\section{Ishikura 1998 \{published data only\}}

Ishikura H, Yamagami K, Akahori M, Shoji Y, Fukui H, Tanaka T. Changes in blood platelet count and serum thrombopoetin (TPO) level under moderate hypothermic therapy in traumatic severe closed head injury. Critical Care Medicine 1998;26(Suppl 1):A82.

\section{Jiang 2000 \{published data only\}}

* Jiang J, Yu M, Zhu C. Effect of long-term mild hypothermia therapy in patients with severe traumatic brain injury: 1year follow-up review of 87 cases. Journal of Neurosurgery 2000;93(4):546-9. [PUBMED: 11014530]

Jiang JY, Zhu C. The mild hypothermia significantly decreases mortality of severe traumatic brain injured patients. International Conference on Recent Advances in Neurotraumatology; 1996 September 8-11; Riccione, Italy. 1996.

\section{Lee 2010 \{published data only\}}

Lee HC, Chuang HC, Cho DY, Cheng K F, Lin PH, Chen CC. Applying cerebral hypothermia and brain oxygen monitoring in treating severe traumatic brain injury. World Neurosurgery 2010;74(6):654-60. [PUBMED: 21492636]

\section{Li 2008 \{published data only\}}

Li G, Xu R, Ke Y, Jiang X, Zhang S, Deng B, et al. Effect of subhypothermia therapy on coagulopathy after severe head injury. Chinese Medical Journal 2008;121(22):2350-2. [PUBMED: 19080347]

\section{Li 2009 \{published data only\}}

Li H, Lu G, Shi W, Zheng S. Protective effect of moderate hypothermia on severe traumatic brain injury in children. Journal of Neurotrauma 2009;26(11):1905-9. [PUBMED: 19469686]

\section{Marion 1997 \{published data only\}}

Clark RS, Kochanek PM, Obrist WD, Wong HR, Billiar TR, Wisniewski SR, et al. Cerebrospinal fluid and plasma nitrite and nitrate concentrations after head injury in humans. Critical Care Medicine 1996;24(7):1243-51. [PUBMED: 8674343]

Darby JM, Marion DW, Peitzman A, Carlier P, Obrist WD. Pulmonary complications in brain-injured patients treated with hypothermia. Anesthesiology 1992;77:A295.

Marion DW, Carlier P. Moderate therapeutic hypothermia improves outcome following severe traumatic brain injury. Third International Neurotrauma Symposium; 1995 July 22-27; 
Toronto, Canada. Please add: International Neurotrauma Society, 1995.

Marion DW, Obrist WD, Carlier PM, Penrod LE, Darby JM. The use of moderate therapeutic hypothermia for patients with severe head injuries: a preliminary report. Journal of Neurosurgery 1993;79(3):354-62. [PUBMED: 8360731]

Marion DW, Palmer AM, DeKosky ST, Kochanek PM, Carlier PM. Effect of moderate hypothermia on neurochemical mediators of secondary brain injury. Journal of Neurosurgery 1995;82:344A.

* Marion DW, Penrod LE, Kelsey SF, Obrist WD, Kochanek PM, Palmer AM, et al. Treatment of traumatic brain injury with moderate hypothermia. New England Journal of Medicine 1997;336(8):540-6. [PUBMED: 9023090]

Marion DW, Penrod LE, Kelsey SF, Obrist WD, Kochanek PM, Palmer AM, et al. Treatment of traumatic brain injury with moderate hypothermia. Tenth International Symposium on Intracranial Pressure and Neuromonitoring in Brain Injury; 1997 May 25-29; Williamsburg, USA. 1997.

Resnick DK, Marion DW, Darby JM. The effect of hypothermia on the incidence of delayed traumatic intracerebral hemorrhage. Neurosurgery 1994;34(2):252-5. [PUBMED: 8177385]

\section{Meissner 2003a \{published data only\}}

Meissner W, Fritz H, Dohm B, Krapp C, Reinhart K. Hormonal and haemodynamic consequences of moderate hypothermia in head injured patients. Neurosciences 2003:A350: 02-3.

\section{Meissner 2003b \{published data only\}}

Meissner W, Krapp C, Kauf E, Dohrn B, Reinhart K. Thyroid hormone response to moderate hypothermia in severe brain injury. Intensive Care Medicine 2003;29(1):44-8. [PUBMED: 12528021]

\section{Qiu 2005 \{published data only\}}

Qiu WS, Lin WG, Shen H, Wang WM, Zhang Z, Zhang Y, et al. Therapeutic effect of mild hypothermia on severe traumatic head injury. Chinese Journal of Traumatology 2005;8(1):27-32. [PUBMED: 15676086]

\section{Qiu 2007 \{published data only\}}

Qiu W, Zhang Y, Sheng H, Zhang J, Wang W, Liu W, et al. Effects of therapeutic mild hypothermia on patients with severe traumatic brain injury after craniotomy. Journal of Critical Care 2007;22(3):229-36. [PUBMED: 17869973]

\section{Shiozaki 1993 \{published data only\}}

Shiozaki T, Sugimoto H, Taneda M, Yoshida H, Iwai A, Yoshioka T, et al. Effect of mild hypothermia on uncontrollable intracranial hypertension after severe head injury. Journal of Neurosurgery 1993;79(3):363-8. [PUBMED: 8360732]

\section{Shiozaki 1999 \{published data only\}}

Shiozaki T, Kato A, Taneda M, Hayakata T, Hashiguchi N, Tanaka $\mathrm{H}$, et al. Little benefit from mild hypothermia therapy for severely head injured patients with low intracranial pressure. Journal of Neurosurgery 1999;91(2):185-91. [PUBMED: 10433305]

\section{Shiozaki 2001 \{published data only\}}

Shiozaki T, Hayakata T, Taneda M, Nakajima Y, Hashiguchi N, Fujimi S, et al. A multicenter prospective randomised controlled trial of the efficacy of mild hypothermia for severely head injured patients with low intracranial pressure. Mild Hypothermia Study Group in Japan. Journal of Neurosurgery 2001;94(1):50-4. [PUBMED: 1147897]

\section{Smrcka 2005 \{published data only\}}

Smrcka M, Vidlák M, Máca K, Smrcka V, Gál R. The influence of mild hypothermia on ICP, CPP and outcome in patients with primary and secondary brain injury. Acta Neurochirurgica. Supplement 2005;95:273-5. [PUBMED: 16463864]

Wang 2005 \{published data only\}

Wang W, Ren HJ, Chi JY, Xu FL, Quan Y. Effects of mild hypothermia on patients with lower intracranial pressure following severe brain injury. Chinese Journal of Traumatology 2005;8(1):54-56. [PUBMED: 15676092]

Yan 2001 \{published data only\}

Yan Y, Tang W. Changes of evoked potentials and evaluation of mild hypothermia for treatment of severe brain injury. Chinese Journal of Traumatology 2001;4(1):8-13. [PUBMED: 11835701]

Yan 2010 \{published data only\}

Yan Y, Tang W, Deng Z, Zhong D, Yang G. Cerebral oxygen metabolism and neuroelectrophysiology in a clinical study of severe brain injury and mild hypothermia. Journal of Clinical Neuroscience 2010;17(2):196-200. [PUBMED: 20036549]

\section{Zhang 2000 \{published data only\}}

Zhang K, Wang JX. Comparative study on mild hypothermia in patients with severe head injury and the most severe head injury. Inner Mongolia Medical Journal 2000;32:4-6.

\section{Zhao 2011 \{published data only\}}

Zhao QJ, Zhang XG, Wang LX. Mild hypothermia therapy reduces blood glucose and lactate and improves neurologic outcomes in patients with severe traumatic brain injury. Journal of Critical Care 2011;26(3):311-5. [PUBMED: 20889287]

\section{Zhi 2003 \{published data only\}}

Zhi D, Zhang S, Lin X. Study on therapeutic mechanism and clinical effect of mild hypothermia in patients with severe head injury. Surgical Neurology 2003;59(5):381-5. [PUBMED: 12765810]

\section{References to studies excluded from this review \\ ACTRN12615001119583p \{published data only\}}

ACTRN12615001119583p. Target temperature management for traumatic brain injury: a feasibility study of pyrexia control. www.anzctr.org.au/Trial/Registration/TrialReview.aspx? ACTRN=12615001119583 (accessed 20 September 2016).

\section{Maekawa 2015 \{published data only\}}

Hifumi T, Kuroda Y, Kawakita K, Yamashita S, Oda Y, Dohi K, et al. Fever control management is preferable to mild therapeutic hypothermia in traumatic brain injury patients with Abbreviated 
Injury Scale 3-4: a multi-center, randomised controlled trial. Journal of Neurotrauma 2016;33(11):1047-53. [PUBMED: 26413933]

Maekawa T, Yamashita S, Nagao S, Hayashi N, Ohashi Y. Prolonged mild therapeutic hypothermia versus fever control with tight hemodynamic monitoring and slow rewarming in patients with severe traumatic brain injury: a randomised controlled trial. Journal of Neurotrauma 2015;32(7):422-9. [PUBMED: 25099730]

\section{Meissner 1998 \{published data only\}}

Meissner W, Fritz H, Dohrn B, Specht M, Reinhart K. Influence of hypothermia on cytokine concentrations in head injured patients. Critical Care Medicine 1998;26(Suppl 1):A82.

\section{NCT01333488 \{published data only\}}

NCT01333488. Mild hypothermia and supplemental magnesium sulfate infusion in severe traumatic brain injury (TBI) subjects [A phase 2, randomised, controlled $2 \times 3$ trial comparing clinical outcomes in patients with severe traumatic brain injury using mild hypothermia and concurrent and supplemental infusion of magnesium sulfate]. clinicaltrials.gov/ct2/show/NCT01333488? term=NCT01333488\&rank=1 (first received April 2011).

\section{NCT02353793 \{published data only\}}

NCT02353793. Trauma patients and hypothermia in the emergency room: ReadyHeat ${ }^{\circledR}$ versus cotton wool blanket [Trauma patients and hypothermia in the emergency Room: a trial between self-warming ReadyHeat ${ }^{\circledR}$ blanket and traditional cotton wool blanket]. clinicaltrials.gov/ct2/show/NCT02353793 (first received 15 December 2015).

\section{Rincon 2014 \{published data only\}}

Rincon F, Friedman DP, Bell R, Mayer SA, Bray PF. Targeted temperature management after intracerebral hemorrhage (TTM-ICH): methodology of a prospective randomised clinical trial. International Journal of Stroke 2014;9(5):646-651. [PUBMED: 24450819]

\section{Wang 2007 \{published data only\}}

Wang Q, Li A, Zhi D, Huang H. Effect of mild hypothermia on glucose metabolism and glycerol of brain tissue in patients with severe traumatic brain injury. Chinese Journal of Traumatology 2007;10(4):246-9. [PUBMED: 17651596]

\section{Yan 2007 \{published data only\}}

Yan Y, Tang W, He J. Clinical research about brain oxygen metabolism and neuroelectrophysiology during mild hypothermia in patients with severe head injury. Zhonghua Wai Ke Za Zhi 2007;45(2):109-13. [PUBMED: 17418039]

\section{References to studies awaiting assessment}

\section{Gál 2012 \{published data only\}}

Gál R, Smrcka M, Slezak M, Colonova M, Mrlian A. Mild hypothermia therapy for patients with severe brain injury: clinical study. Brain Injury 2012; Vol. 26, issue 4-5:629-30. [WOS:000304104600573]
Tang 2017 \{published data only\}

Tang C, Bao Y, Qi M, Zhou L, Liu F, Mao J, et al. Mild induced hypothermia for patients with severe traumatic brain injury after decompressive craniectomy. Journal of Critical Care 2017;39:267-70. [PUBMED: 28069320]

\section{References to ongoing studies}

Lei 2015 \{published data only\} Lei J, Gao G, Mao Q, Feng J, Wang L, You W, et al. Rationale, methodology, and implementation of a nationwide multicenter randomised controlled trial of long-term mild hypothermia for severe traumatic brain injury (the LTH-1 trial). Contemporary Clinical Trials 2015;40:9-14. [PUBMED: 25460339]

\section{Nichol 2015 \{published data only\}}

Nichol A, Gantner D, Presneill J, Murray L, Trapani T, Bernard S, et al. Protocol for a multicentre randomised controlled trial of early and sustained prophylactic hypothermia in the management of traumatic brain injury. Critical Care and Resuscitation 2015;17(2):92-100. [PUBMED: 26017126]

\section{Additional references}

\section{Adelson 2003}

Adelson PD, Bratton SL, Carney NA, Chestnut RM, Coudray HEM, Goldstein B, et al. Guidelines for the acute medical management of severe traumatic brain injury in infants, children, and adolescents. Pediatric Critical Care Medicine 2003;4(3 (Suppl)):S1-75. [DOI: 10.1097/01.CCM.0000067635.95882.24]

\section{Bering 1961}

Bering EA Jr. Effect of body temperature change on cerebral oxygen consumption of the intact monkey. American Journal of Physiology 1961;200:417-9.

\section{Bullock 1996}

Bullock R, Chesnut RM, Clifton G, Ghajar J, Marion DW, Narayan RK, et al. Guidelines for the management of severe head injury. Journal of Neurotrauma 1996;13:639-734.

\section{Bullock 2007}

Bullock MR, Povlishock JT. Guidelines for the management of severe head injury. Journal of Neurotrauma 2007;24(Suppl 1):S1-106. [DOI: 10.1089/neu.2007.9976]

\section{Busto 1987}

Busto R, Dietrich WD, Globus MY, Valdés I, Scheinberg P, Ginsberg MD. Small differences in intra-ischemic brain temperature critically determine the extent of ischemic neuronal injury. Journal of Cerebral Blood Flow Metabolism 1987;7(6):729-38.

\section{Busto 1989}

Busto R, Globus MY, Dietrich WD, Martinez E, Valdés I, Ginsberg MD. Effect of mild hypothermia on ischemia-induced release of neuro-transmitters and free fatty acids in rat brain. Stroke 1989;20(7):904-10. 


\section{Carney 2016}

Carney N, Totten A, O'Reilly C, Ullman JS, Hawryluk GWJ, Bell MJ, et al. Guidelines for the Management of Severe Traumatic Brain Injury, Fourth Edition. Neurosurgery 2017;80(1):6-15.

\section{Clasen 1968}

Clasen RA, Pandolfi S, Russell J, Stuart D, Hass GM. Hypothermia and hypotension in experimental cerebral edema. Archives of Neurology 1968;19(5):472-86.

\section{Clifton 1995}

Clifton GL. Systemic hypothermia in treatment of severe brain injury: a review and update 1995. Journal of Neurotrauma 1995;12(5):923-7.

\section{Clifton 2011b}

Clifton GL. A review of clinical trials of hypothermia treatment for severe traumatic brain injury. Therapeutic Hypothermia and Temperature Management 2011;1(3):143-9. [PUBMED: 24717043]

\section{Crossley 2014}

Crossley S, Reid J, McLatchie R, Hayton J, Clark C, MacDougall $M$, et al. A systematic review of therapeutic hypothermia for adult patients following traumatic brain injury. Critical Care 2014;18(2):R75. [PUBMED: 24742169]

\section{Egger 1997}

Egger M, Davey Smith G, Schneider M, Minder C. Bias in metaanalysis detected by a simple, graphical test. BMJ (Clinical Research Ed.) 1997;315(7109):629-34. [PUBMED: 9310563]

\section{Fay 1945}

Fay T. Observations on generalized refrigeration in cases of severe cerebral trauma. Association for Research in Nervous and Mental Disease 1945;24:611-9.

\section{Georgiou 2013}

Georgiou AP, Manara AR. Role of therapeutic hypothermia in improving outcome after traumatic brain injury: a systematic review. British Journal of Anaesthesia 2013;110(3):357-67. [PUBMED: 23353036]

\section{GRADEpro GDT 2015 [Computer program]}

McMaster University (developed by Evidence Prime). GRADEpro GDT. Version (accessed 29 September 2017). Hamilton (ON): McMaster University (developed by Evidence Prime), 2015.

\section{Guyatt 2011}

Guyatt GH, Oxman AD, Kunz R, Brozek J, Alonso-Coello P, Rind $D$, et al. GRADE guidelines 6 . Rating the quality of evidence--imprecision. Journal of Clinical Epidemiology 2011;64(12):1283-93. [PUBMED: 21839614]

\section{Higgins 2011}

Higgins JPT, Green S (editors). Cochrane Handbook for Systematic Reviews of Interventions. The Cochrane Collaboration 2011; Vol. Version 5.1.0 [updated March 2011]:www.cochrane-handbook.org.

\section{Kirkpatrick 1997}

Kirkpatrick PJ. On guidelines for the management of severe head injury. Journal of Neurology, Neurosurgery and Psychiatry 1997;62(2):109-11. [PUBMED: 9048708]

\section{Langlois 2006}

Langlois JA, Rutland-Brown W, Wald MM. The epidemiology and impact of traumatic brain injury: a brief overview. Journal of Head Trauma Rehabilitation 2006;21(5):375-8. [PUBMED: 16983222]

\section{Laskowski 1960}

Laskowski EJ, Klato I, Baldwin M. Experimental study on the effects of hypothermia on local brain injury. Neurology 1960;10:499-505. [PUBMED: 14414367]

\section{Lefebvre 2011}

Lefebvre C, Manheimer E, Glanville J. Chapter 6: Searching for studies. In: Higgins JPT, Green S (editors). Cochrane Handbook for Systematic Reviews of Interventions.Version 5.1.0 (updated March 2011).The Cochrane Collaboration, 2011. www.cochranehandbook.org.

\section{Review Manager (RevMan) [Computer program]}

The Nordic Cochrane Center. Review Manager (RevMan). Version 5.3.0. Copenhagen: The Cochrane Collaboration, 2014.

\section{Schubert 1995}

Schubert A. Side effects of mild hypothermia. Journal of Neurosurgical Anesthesiology 1995;7(2):139-47. [PUBMED: 7772968]

\section{Sedzimir 1959}

Sedzimir CB. Therapeutic hypothermia in cases of head injury. Journal of Neurosurgery 1959;16(4):407-14. [PUBMED: 13665397]

\section{Shapiro 1974}

Shapiro HM, Wyte SR, Loeser J. Barbiturate-augmented hypothermia for reduction of persistent intracranial hypertension. Journal of Neurosurgery 1974;40(1):90-100. [PUBMED: 4808489]

\section{Smith 1996}

Smith SL, Hall ED. Mild pre- and posttraumatic hypothermia attenuates blood-brain barrier damage following controlled cortical impact injury in the rat. Journal of Neurotrauma 1996;13(1):1-9. [PUBMED: 8714857]

\section{References to other published versions of this review Alderson 2004}

Alderson P, Signorini D, Patil C. Therapeutic hypothermia for head injury. Cochrane Database of Systematic Reviews 2004, Issue 4. [DOI: 10.1002/14651858.CD001048.pub2]

\section{Gadkary 2002}

Gadkary CA, Alderson P, Signorini DF. Therapeutic hypothermia for head injury. Cochrane Database of Systematic Reviews 2002, Issue 1. [DOI: 10.1002/14651858.CD001048] 


\section{Sydenham 2009a}

Sydenham E, Roberts I, Alderson P. Hypothermia for traumatic head injury. Cochrane Database of Systematic Reviews 2009, Issue 1. [DOI: 10.1002/14651858.CD001048.pub3]

\section{Sydenham 2009b}

Sydenham E, Roberts I, Alderson P. Hypothermia for traumatic head injury. Cochrane Database of Systematic Reviews 2009, Issue 2. [DOI: 10.1002/14651858.CD001048.pub4]

* Indicates the major publication for the study

\section{CHARACTERISTICS OF STUDIES}

Characteristics of included studies [ordered by study ID]

Adelson 2005 HYPO 1

\begin{tabular}{|c|c|}
\hline Methods & Randomised controlled trial, parallel group \\
\hline \multirow[t]{14}{*}{ Participants } & Total number of participants: 48 \\
\hline & Baseline characteristics: \\
\hline & Therapeutic cooling \\
\hline & Age: mean (SD) $6.92( \pm 3.09)$ years \\
\hline & Type of injury (closed/open): closed \\
\hline & GCS on admission: mean (SD) 5.74 ( \pm 1.39$)$ \\
\hline & No cooling \\
\hline & Age: mean $(\mathrm{SD}) 6.86( \pm 3.81)$ years \\
\hline & Type of injury (closed/open): closed \\
\hline & GCS on admission: mean (SD) $5.64( \pm 1.63)$ \\
\hline & $\begin{array}{l}\text { Inclusion criteria: children } 0 \text { to } 156 \text { months of age, with non-penetrating head injury, GCS } \leq 8 \text {, motor } \\
\text { score }<6\end{array}$ \\
\hline & $\begin{array}{l}\text { Exclusion criteria: normal initial CT scan, extended hypotension for }>15 \text { minutes, coagulopathy ad- } \\
\text { mission }>6 \text { hours after injury, brain death on initial examination }\end{array}$ \\
\hline & Country: USA \\
\hline & Setting: hospital. 6 medical centres \\
\hline
\end{tabular}

\section{Therapeutic cooling}

Number of participants randomised: 23

Method of cooling: surface cooling using a hypothermia/heating blanket. Sedation and paralysis induced to prevent shivering

Target temperature: 32 to $33^{\circ} \mathrm{C}$

Time of cooling: $<6$ hours

Duration of cooling: 48 hours

Rewarming details: after 48 hours, passive warming, $1^{\circ} \mathrm{C}$ every 3 to 4 hours until $36.5^{\circ} \mathrm{C}$ reached. Initiation of warming not stopped due to intracranial hypotension but slowed at times due to elevations in ICP

Site of temperature measurement: rectal

\section{No cooling}


Adelson 2005 HYPO 1 (Continued)

\section{Number of participants: 25}

Method of temperature management: participants were passively warmed if their initial presenting core temperature was $<36{ }^{\circ} \mathrm{C}$

Target temperature: 36.5 to $37.5^{\circ} \mathrm{C}$

\begin{tabular}{ll}
\hline Outcomes & $\begin{array}{l}\text { Outcomes measured in study: mortality, ventricular arrhythmias, delayed intracranial haemorrhage, in } \\
\text { tra-abdominal/thoracic bleeding, coagulopathy infection (pneumonia), GOS (at } 3 \text { and } 6 \text { months), age- } \\
\text { appropriate neurocognitive tests, intracranial pressure, other secondary clinical outcomes }\end{array}$ \\
\hline Notes & $\begin{array}{l}\text { Funding/declarations of interest: National Institute of Health grant, General Clinical Research Centre at } \\
\text { Children's Hospital of Pittsburgh grant }\end{array}$ \\
& Study dates: July 1999 to December 2003 \\
& $\begin{array}{l}\text { Note: study authors reported GOS at } 3 \text { months as "no difference between treatment groups" with P = } \\
\text { 0.799; and GOS at } 6 \text { months with P }=0.540\end{array}$
\end{tabular}

\section{Risk of bias}

\begin{tabular}{|c|c|c|}
\hline Bias & Authors' judgement & Support for judgement \\
\hline $\begin{array}{l}\text { Random sequence genera- } \\
\text { tion (selection bias) }\end{array}$ & Unclear risk & $\begin{array}{l}\text { Described as randomised and stratification done by age of child at time of in- } \\
\text { jury. No additional details }\end{array}$ \\
\hline $\begin{array}{l}\text { Allocation concealment } \\
\text { (selection bias) }\end{array}$ & Unclear risk & Insufficient details provided \\
\hline $\begin{array}{l}\text { Blinding of participants } \\
\text { and personnel (perfor- } \\
\text { mance bias): mortality }\end{array}$ & Low risk & Not possible to blind personnel; unlikely to influence performance \\
\hline $\begin{array}{l}\text { Blinding of participants } \\
\text { and personnel (perfor- } \\
\text { mance bias): GOS }\end{array}$ & Unclear risk & Not possible to blind personnel; unclear if this would influence performance \\
\hline $\begin{array}{l}\text { Blinding of participants } \\
\text { and personnel (perfor- } \\
\text { mance bias): pneumonia }\end{array}$ & Unclear risk & Not possible to blind personnel; unclear if this would influence performance \\
\hline $\begin{array}{l}\text { Blinding of outcome as- } \\
\text { sessment (detection bias): } \\
\text { mortality; pneumonia }\end{array}$ & Low risk & Lack of blinding unlikely to influence outcome assessment \\
\hline $\begin{array}{l}\text { Blinding of outcome as- } \\
\text { sessment (detection bias): } \\
\text { GOS }\end{array}$ & Low risk & $\begin{array}{l}\text { Neurocognitive tests were performed by the site neuropsychologist or techni- } \\
\text { cian who were blinded to the therapeutic intervention }\end{array}$ \\
\hline $\begin{array}{l}\text { Incomplete outcome data } \\
\text { (attrition bias) } \\
\text { All outcomes }\end{array}$ & Low risk & $\begin{array}{l}\text { Low for mortality and pneumonia. Small loss of follow-up at } 3 \text { and } 6 \text { months } \\
\text { for GOS data, although not reported by treatment groups }\end{array}$ \\
\hline $\begin{array}{l}\text { Selective reporting (re- } \\
\text { porting bias) }\end{array}$ & Unclear risk & $\begin{array}{l}\text { Clinical trials registration or pre-published protocol not reported. Insufficient } \\
\text { information to make judgement }\end{array}$ \\
\hline Other bias & Low risk & No other sources of bias identified \\
\hline
\end{tabular}




\begin{tabular}{|c|c|}
\hline Methods & Randomised controlled trial, parallel group \\
\hline \multirow[t]{14}{*}{ Participants } & Total number of participants: 27 \\
\hline & Baseline characteristics: \\
\hline & Therapeutic cooling \\
\hline & Age: mean (SD) $7.17( \pm 6.64)$ years \\
\hline & Type of injury (closed/open): closed \\
\hline & GCS on admission: mean (SD) $6.42( \pm 1.2)$ \\
\hline & No cooling \\
\hline & Age: mean (SD) $5.6( \pm 5.23)$ years \\
\hline & Type of injury (closed/open): closed \\
\hline & GCS on admission: mean (SD) $6.23( \pm 1.2)$ \\
\hline & $\begin{array}{l}\text { Inclusion criteria: children } 0 \text { to } 214 \text { months of age, with non-penetrating head injury, GCS } \leq 8 \text {, within } \\
24 \text { hours of admission }\end{array}$ \\
\hline & $\begin{array}{l}\text { Exclusion criteria: normal initial CT scan, penetrating brain injury, brain death on admission to emer- } \\
\text { gency department, failure to obtain informed consent } 24 \text { hours from admission, uncorrectable coagu- } \\
\text { lopathy (PT/PTT }>16 / 40 \text { seconds), hypotensive episode for }>5 \text { minutes defined as SBP }<\text { fifth percentile } \\
\text { for age }\end{array}$ \\
\hline & Country: USA \\
\hline & Setting: hospital (single centre) \\
\hline
\end{tabular}

\section{Therapeutic cooling}

Number of participants: 14

Method of cooling: surface cooling using a hypothermia/heating blanket. Sedation and paralysis induced to prevent shivering

Target temperature: 32 to $33^{\circ} \mathrm{C}$

Time of cooling: $<6$ hours

Duration of cooling: 48 hours

Rewarming details: after 48 hours, passive warming, $1^{\circ} \mathrm{C}$ every 3 to 4 hours until $36.5^{\circ} \mathrm{C}$ reached. Initiation of warming not stopped due to intracranial hypotension but slowed at times due to elevations in ICP

Site of temperature measurement: rectal

\section{No cooling}

Number of participants: 13

Method of temperature management: participants were passively warmed if their initial presenting core temperature was $<36^{\circ} \mathrm{C}$

Target temperature: 36.5 to $37.5^{\circ} \mathrm{C}$ 
Adelson 2005 HYPO 2 (Continued)

Outcomes

Outcomes measured in study: mortality, ventricular arrhythmias, delayed intracranial haemorrhage, intraabdominal/thoracic bleeding, coagulopathy infection (pneumonia), GOS, Infant Health Questionnaire, Vineland Adaptive Behaviour scale, ICP, other secondary clinical outcomes

Notes Funding/declarations of interest: National Institute of Health grant, General Clinical Research Centre at Children's Hospital of Pittsburgh grant

Study dates: August 2001 to December 2003

Note: HYPO 2 was a single-centre trial set up later due to recruitment issues in HYPO 1, but running in parallel to HYPO 1 with a different inclusion criteria. All other methods and outcomes were the same as HYPO 1

\section{Risk of bias}

\begin{tabular}{|c|c|c|}
\hline Bias & Authors' judgement & Support for judgement \\
\hline $\begin{array}{l}\text { Random sequence genera- } \\
\text { tion (selection bias) }\end{array}$ & Unclear risk & $\begin{array}{l}\text { Described as randomised and stratification done by age of child at time of in- } \\
\text { jury. No additional details }\end{array}$ \\
\hline $\begin{array}{l}\text { Allocation concealment } \\
\text { (selection bias) }\end{array}$ & Unclear risk & Insufficient details provided \\
\hline $\begin{array}{l}\text { Blinding of participants } \\
\text { and personnel (perfor- } \\
\text { mance bias): mortality }\end{array}$ & Low risk & Not possible to blind personnel; unlikely to influence performance \\
\hline $\begin{array}{l}\text { Blinding of participants } \\
\text { and personnel (perfor- } \\
\text { mance bias): GOS }\end{array}$ & Unclear risk & Not possible to blind personnel; unclear if this would influence performance \\
\hline $\begin{array}{l}\text { Blinding of participants } \\
\text { and personnel (perfor- } \\
\text { mance bias): pneumonia }\end{array}$ & Unclear risk & Not possible to blind personnel; unclear if this would influence performance \\
\hline $\begin{array}{l}\text { Blinding of outcome as- } \\
\text { sessment (detection bias): } \\
\text { mortality; pneumonia }\end{array}$ & Low risk & Lack of blinding unlikely to influence outcome assessment \\
\hline $\begin{array}{l}\text { Blinding of outcome as- } \\
\text { sessment (detection bias): } \\
\text { GOS }\end{array}$ & Low risk & $\begin{array}{l}\text { Neurocognitive tests (GOS) were performed by the site neuropsychologist or } \\
\text { technician who were blinded to the therapeutic intervention }\end{array}$ \\
\hline $\begin{array}{l}\text { Incomplete outcome data } \\
\text { (attrition bias) } \\
\text { All outcomes }\end{array}$ & Low risk & $\begin{array}{l}\text { Low for mortality and pneumonia. Small loss of follow-up at } 3 \text { and } 6 \text { months } \\
\text { for GOS data, not reported by treatment groups. }\end{array}$ \\
\hline $\begin{array}{l}\text { Selective reporting (re- } \\
\text { porting bias) }\end{array}$ & Unclear risk & $\begin{array}{l}\text { Clinical trials registration or pre-published protocol not reported. Insufficient } \\
\text { information to make judgement }\end{array}$ \\
\hline Other bias & Low risk & No other sources of bias identified \\
\hline
\end{tabular}

Adelson 2013

Methods Randomised controlled trial, parallel design


Adelson 2013 (Continued)

Participants
Total number of participants: 77

\section{Baseline characteristics:}

\section{Therapeutic cooling}

Age: median (IQR) 9.7 (4.2 to 14.5 ) years

Gender: 21/18

Weight (kg): median (IQR) 30 (15.4 to 62)

Type of injury (closed/open): closed

GCS: median (IQR) 6 (5 to 7 )

\section{No cooling}

Age: median (IQR) 12.5 (3.3 to 14.8 ) years

Gender M/F: 27/11

Weight (kg): median (IQR) 38 (16 to 60)

Type of injury (closed/open): closed

GCS on admission: median (IQR) 6 (5 to 7 )

Inclusion criteria: 0 to 17 years of age, non-penetrating brain injury, GCS 3 to 8 , motor score on GCS $<6$ after resuscitation, within 6 hours of injury

Exclusion criteria: normal CT, GCS 3, unreactive pupils, hypotension for $>10$ minutes, uncorrectable coagulopathy, hypoxia, abbreviated injury severity score of $\geq 4$ for organs other than the brain, suspected pregnancy, or unavailable parent or guardian to consent

Country: 15 sites across USA, New Zealand and Australia

Setting: emergency department and ICU

\section{Therapeutic cooling}

Number of participants: 39

Method of cooling: cold IV saline 20 to $30 \mathrm{~mL} / \mathrm{kg}$ followed by surface cooling with a cooling mattress

Target temperature: 32 to $33^{\circ} \mathrm{C}$

Time of cooling: within 6 hours of injury

Duration of cooling: 48 hours

Rewarming details: 0.5 to $1{ }^{\circ} \mathrm{C}$ every 12 to 24 hours

Site of temperature measurement: rectal or brain

\section{No cooling}

Number of participants: 38

Method of temperature management: warming/cooling mattress to maintain normothermia

Target temperature: 36.5 to $37.5^{\circ} \mathrm{C}$

Outcomes Outcomes measured in study: 3 month mortality, GOS, GOS-E Peds, adverse events, serious adverse events (to include pneumonia) 
Adelson 2013 (Continued)

Notes
Funding/declarations of interest: National Institute of Neurological Disorders and Stroke and National Institutes of Health. Sponsor had no role in data collection, analysis or interpretation, but involved in study design.

Study dates: November 2007 to February 2011

Note: trial stopped for futility. Clinical trials registration NCT00222742

\section{Risk of bias}

\begin{tabular}{|c|c|c|}
\hline Bias & Authors' judgement & Support for judgement \\
\hline $\begin{array}{l}\text { Random sequence genera- } \\
\text { tion (selection bias) }\end{array}$ & Low risk & "web-based random assignment algorithm" \\
\hline $\begin{array}{l}\text { Allocation concealment } \\
\text { (selection bias) }\end{array}$ & Low risk & $\begin{array}{l}\text { "Randomisation was done by the site study coordinator after screening for eli- } \\
\text { gibility" }\end{array}$ \\
\hline $\begin{array}{l}\text { Blinding of participants } \\
\text { and personnel (perfor- } \\
\text { mance bias): mortality }\end{array}$ & Low risk & $\begin{array}{l}\text { "Emergency service personnel, study nurses involved in randomisation, and } \\
\text { personnel who managed the patients were unmasked to treatment" } \\
\text { Lack of blinding unlikely to influence performance }\end{array}$ \\
\hline $\begin{array}{l}\text { Blinding of participants } \\
\text { and personnel (perfor- } \\
\text { mance bias): GOS }\end{array}$ & Unclear risk & $\begin{array}{l}\text { "Emergency service personnel, study nurses involved in randomisation, and } \\
\text { personnel who managed the patients were unmasked to treatment" } \\
\text { Unclear if lack of blinding would influence performance }\end{array}$ \\
\hline $\begin{array}{l}\text { Blinding of participants } \\
\text { and personnel (perfor- } \\
\text { mance bias): pneumonia }\end{array}$ & Unclear risk & $\begin{array}{l}\text { "Emergency service personnel, study nurses involved in randomisation, and } \\
\text { personnel who managed the patients were unmasked to treatment" } \\
\text { Unclear if lack of blinding would influence performance }\end{array}$ \\
\hline $\begin{array}{l}\text { Blinding of outcome as- } \\
\text { sessment (detection bias): } \\
\text { mortality; pneumonia }\end{array}$ & Low risk & "Investigators who assessed outcomes were masked to treatment allocation" \\
\hline $\begin{array}{l}\text { Blinding of outcome as- } \\
\text { sessment (detection bias): } \\
\text { GOS }\end{array}$ & Low risk & "Investigators who assessed outcome were masked to treatment allocation" \\
\hline $\begin{array}{l}\text { Incomplete outcome data } \\
\text { (attrition bias) } \\
\text { All outcomes }\end{array}$ & Low risk & $\begin{array}{l}\text { One participant lost to follow-up at } 3 \text { months for Unfavourable outcome, but } \\
\text { small number unlikely to introduce bias }\end{array}$ \\
\hline $\begin{array}{l}\text { Selective reporting (re- } \\
\text { porting bias) }\end{array}$ & Unclear risk & $\begin{array}{l}\text { Prospective clinical trials registration (NCT00222742). Outcomes reported at } 3 \\
\text { months, not } 6 \text { and } 12 \text { months as stated in protocol. Use of GCS also not report- } \\
\text { ed nor subgrouped by age }\end{array}$ \\
\hline Other bias & Low risk & No other sources of bias identified \\
\hline
\end{tabular}

Aibiki 2000

\begin{tabular}{ll}
\hline Methods & Randomised controlled trial, parallel group \\
\hline Participants
\end{tabular}


Aibiki 2000 (Continued)

\section{Baseline characteristics:}

\section{Therapeutic cooling}

Age: range 9 to 76 years. Mean (SD) $34( \pm 6)$ years

Type of injury: not stated that participants required 'closed' injury for study inclusion. However, participants' diagnoses were for cerebral contusion, epidural haematoma, subdural haematoma, traumatic subarachnoid haemorrhage, intracerebral haematoma, and diffuse axonal injury

Gender M/F: 12/3

GCS on admission: mean (SD) 5.7 ( \pm 0.3$)$

\section{No cooling}

Age: range 4 to 76 . Mean (SD) $38( \pm 8)$ years

Type of injury: as above

Gender M/F: 8/3

GCS on admission: mean (SD) $5.7( \pm 0.4)$

Inclusion criteria: $\mathrm{GCS} \leq 8$ points on admission to the emergency room and evidence of injury on CT scan

Exclusion criteria: patients who had abdominal or chest trauma or those who sustained severe pulmonary infection. Patients who were admitted to the hospital $>8$ hours after injury

Country: Japan

Setting: hospital

\section{Therapeutic cooling}

Number of participants: 15

Method of cooling: maintained by surface cooling - no further details

Target temperature: 32 to $33^{\circ} \mathrm{C}$

Time of cooling: within 3 to 4 hours after injury

Duration of cooling: normally 3 to 4 days

Rewarming details: started if no signs of brain swelling on CT findings and no ICP elevation. Rewarming at rate of $1^{\circ} \mathrm{C}$ per day

Site of temperature measurement: not stated

\section{No cooling}

Number of participants: 11

Target temperature: 36 to $37^{\circ} \mathrm{C}$

Outcomes

Outcomes measured in study: imbalance of thromboxane B2 (TXB2), 6-keto prostaglandin F1a (6-keto PGF1a), GOS at 6 months (to include mortality data at 6 months), complications (to include pneumonia)

Notes $\quad \begin{aligned} & \text { Funding/declarations of interest: not reported } \\ & \text { Study dates: not reported }\end{aligned}$


Aibiki 2000 (Continued)

\section{Risk of bias}

\begin{tabular}{|c|c|c|}
\hline Bias & Authors' judgement & Support for judgement \\
\hline $\begin{array}{l}\text { Random sequence genera- } \\
\text { tion (selection bias) }\end{array}$ & Unclear risk & Described as randomised; no additional details \\
\hline $\begin{array}{l}\text { Allocation concealment } \\
\text { (selection bias) }\end{array}$ & Unclear risk & No details \\
\hline $\begin{array}{l}\text { Blinding of participants } \\
\text { and personnel (perfor- } \\
\text { mance bias): mortality }\end{array}$ & Low risk & Not possible to blind personnel; unlikely to influence performance \\
\hline $\begin{array}{l}\text { Blinding of participants } \\
\text { and personnel (perfor- } \\
\text { mance bias): GOS }\end{array}$ & Unclear risk & Not possible to blind personnel; unclear if this would influence performance \\
\hline $\begin{array}{l}\text { Blinding of participants } \\
\text { and personnel (perfor- } \\
\text { mance bias): pneumonia }\end{array}$ & Unclear risk & Not possible to blind personnel; unclear if this would influence performance \\
\hline $\begin{array}{l}\text { Blinding of outcome as- } \\
\text { sessment (detection bias): } \\
\text { mortality; pneumonia }\end{array}$ & Low risk & Lack of blinding unlikely to influence outcome assessment \\
\hline $\begin{array}{l}\text { Blinding of outcome as- } \\
\text { sessment (detection bias): } \\
\text { GOS }\end{array}$ & Unclear risk & $\begin{array}{l}\text { "Independent neurosurgeons who were not aware of the study presented here } \\
\text { determined the neurological outcome } 6 \text { months after injury" }\end{array}$ \\
\hline \multirow{2}{*}{$\begin{array}{l}\text { Incomplete outcome data } \\
\text { (attrition bias) } \\
\text { All outcomes }\end{array}$} & Unclear risk & $\begin{array}{l}\text { "Unequal number of patients in each group was the result of exclusion of nor- } \\
\text { mothermic patients having chest or abdominal injuries" }\end{array}$ \\
\hline & & Assume this is a loss of 4 participants but is not clearly stated \\
\hline $\begin{array}{l}\text { Selective reporting (re- } \\
\text { porting bias) }\end{array}$ & Unclear risk & $\begin{array}{l}\text { Clinical trials registration or pre-published protocol not reported. Insufficient } \\
\text { information to make judgement }\end{array}$ \\
\hline Other bias & Low risk & No other sources of bias identified \\
\hline
\end{tabular}

\section{Andrews 2015}

\begin{tabular}{ll}
\hline Methods & Randomised controlled trial, parallel group \\
\hline Participants & Total number of participants: 387 \\
& Baseline characteristics: \\
& Therapeutic cooling \\
& Age: mean (SD) 37.4 ( \pm 15.4 ) years \\
& Type of injury (closed/open): closed \\
& Gender M/F: $157 / 38$ \\
& GCS on admission: GCS 3 to $8: 125 / 195 ;$ GCS 9 to $12: 45 / 195 ;$ GCS 12 to $15: 25 / 195$
\end{tabular}


Andrews 2015 (Continued)

\section{No cooling}

Age: mean (SD) $36.7( \pm 14.9)$ years

Type of injury (closed/open): closed

Gender M/F: 164/28

GCS on admission: GCS 3 to 8: 129/192; GCS 9 to $12: 34 / 192$; GCS 12 to $15: 29 / 192$

Inclusion criteria: primary, closed traumatic brain injury, ICP $>20 \mathrm{mmHg}$ for $\geq 5$ minutes after stage 1 treatments, with no obvious reversible cause, initial head injury that had occurred $\leq 10$ days earlier, availability of a cooling device or technique for $\geq 48$ hours, a core temperature of $\geq 36^{\circ} \mathrm{C}$ (at the time of randomisation), and an abnormal CT scan of the brain. Note change to inclusion criteria part way through trial, to remove upper age limit (previously 65 years) and to increase the time from injury from 72 hours to 10 days.

Exclusion criteria: participants who were already receiving therapeutic hypothermia or who were unlikely to survive for the next 24 hours, administration of barbiturate infusion before randomisation, a temperature of $\leq 34^{\circ} \mathrm{C}$ at hospital admission, and pregnancy

Country: Multicentre trial. 18 countries to include UK

Setting: ICU, hospital

\section{Therapeutic cooling}

Number of participants: 195

Method of cooling: hypothermia was induced by a bolus of intravenous, refrigerated $0.9 \%$ sodium chloride (20 to $30 \mathrm{~mL} / \mathrm{kg}$ of body weight) and thereafter maintained with the usual cooling technique of each site

\section{Target temperature: 32 to $35^{\circ} \mathrm{C}$}

Time of cooling: initial study phase was within 72 hours from time of injury, but investigators altered this to within 10 days after initial head injury

Duration of cooling: $\geq 48$ hours to ensure intracranial pressure maintained

Rewarming details: after 48 hours at a rate of $0.25^{\circ} \mathrm{C}$ per hour, provided that intracranial pressure was $20 \mathrm{mmHg}$ or less

Site of temperature measurement: bladder, oesophageal, pulmonary artery catheter, rectum

\section{No cooling}

Number of participants: 192

Outcomes

Outcomes measured in study: GOS (at 6 months), 6 month mortality, 28 day mortality (reported in supplementary index) lack of ICP, pneumonia, length of ICU stay, score on modified Oxford Handicap Scale, adverse outcomes

Notes Funding/declarations of interest : supported by the National Institute for Health Research Health Technology Assessment program, which funded the main phase of the study. The European Society of Intensive Care Medicine funded the pilot phase. The trial sponsors, the University of Edinburgh and NHS Lothian, provided research governance

Study dates: November 2009 to October 2014

Note: Some data taken from supplementary protocol and appendix available with New England Journal of Medicine online publication of full study report (Andrews 2015)

\section{Risk of bias}

Hypothermia for traumatic brain injury (Review) 
Andrews 2015 (Continued)

\begin{tabular}{|c|c|c|}
\hline Bias & Authors' judgement & Support for judgement \\
\hline $\begin{array}{l}\text { Random sequence genera- } \\
\text { tion (selection bias) }\end{array}$ & Low risk & $\begin{array}{l}\text { Central Internet based randomisation service or a telephone randomisation } \\
\text { service depending on the available technology at each site }\end{array}$ \\
\hline $\begin{array}{l}\text { Allocation concealment } \\
\text { (selection bias) }\end{array}$ & Low risk & Use of external randomisation service \\
\hline \multirow{2}{*}{$\begin{array}{l}\text { Blinding of participants } \\
\text { and personnel (perfor- } \\
\text { mance bias): mortality }\end{array}$} & Low risk & $\begin{array}{l}\text { "Patients, families, and treating clinicians aware of the study-group assign- } \\
\text { ments" }\end{array}$ \\
\hline & & Lack of blinding unlikely to influence performance for this outcome \\
\hline \multirow{2}{*}{$\begin{array}{l}\text { Blinding of participants } \\
\text { and personnel (perfor- } \\
\text { mance bias): GOS }\end{array}$} & Unclear risk & $\begin{array}{l}\text { "Patients, families, and treating clinicians aware of the study-group assign- } \\
\text { ments" }\end{array}$ \\
\hline & & Unclear if lack of blinding would influence performance for this outcome \\
\hline $\begin{array}{l}\text { Blinding of outcome as- } \\
\text { sessment (detection bias): } \\
\text { mortality; pneumonia }\end{array}$ & Low risk & $\begin{array}{l}\text { "An investigator who was unaware of the study-group assignments scored all } \\
\text { outcomes according to the standardized approach" }\end{array}$ \\
\hline $\begin{array}{l}\text { Blinding of outcome as- } \\
\text { sessment (detection bias): } \\
\text { GOS }\end{array}$ & Low risk & $\begin{array}{l}\text { "An investigator who was unaware of the study-group assignments scored all } \\
\text { outcomes according to the standardized approach" }\end{array}$ \\
\hline $\begin{array}{l}\text { Incomplete outcome data } \\
\text { (attrition bias) } \\
\text { All outcomes }\end{array}$ & Low risk & $\begin{array}{l}\text { Some loss of participants not clearly explained, although few in number and } \\
\text { unlikely to influence results }\end{array}$ \\
\hline \multirow[t]{2}{*}{$\begin{array}{l}\text { Selective reporting (re- } \\
\text { porting bias) }\end{array}$} & Unclear risk & $\begin{array}{l}\text { Registered trial (ISRCTN34555414). Pneumonia reported as outcome in the } \\
\text { protocol, but not reported in results. }\end{array}$ \\
\hline & & Supplementary protocol published with full study report \\
\hline Other bias & High risk & $\begin{array}{l}\text { Inclusion criteria altered part way through study to include participants up to } \\
10 \text { days after injury }\end{array}$ \\
\hline
\end{tabular}

Beca 2015

\begin{tabular}{ll}
\hline Methods & Randomised controlled trial, parallel group \\
\hline Participants & Total number of participants: 50 \\
Baseline characteristics: & Therapeutic cooling \\
& Age: median (IQR) 11.0 (6.9 to 14.2$)$ years \\
& Weight $\mathrm{kg}:$ median (IQR) 31.5 (24 to 53$)$ \\
& Type of injury (closed/open): closed \\
Gender M/F: $11 / 13$ \\
GCS on admission: median (IQR) 5.5 (3.5 to 7$)$ \\
No cooling
\end{tabular}


Beca 2015 (Continued)

Age: median (IQR) 9.5 (5.2 to 13.8) years

Weight kg: median (IQR) 30 (20 to 50)

Type of injury (closed/open): closed

Gender M/F: 16/10

GCS on admission: median (IQR) 4.5 (3 to 7 )

Note: difference between groups, with participants in hypothermia group taking longer to get to study site

Inclusion criteria: $>1$ year and $<16$ years of age, mechanically ventilated, GCS $<9$ and an abnormal CT scan (intracranial haemorrhage or contusion, cerebral edema, or diffuse axonal injury)

Exclusion criteria: not able to be randomised within 6 hours after injury or had a penetrating brain injury, fixed dilated pupils and a GCS $=3$, proven cervical spinal cord injury, more than mild developmental disability prior to injury, an acute epidural hematoma evacuated and were expected to recover rapidly, a post-traumatic clinical seizure with a normal CT scan, refractory shock (defined as a MAP $<2$ SDs below mean for age despite $>80 \mathrm{~mL} / \mathrm{kg}$ of IV resuscitation fluid), or suspected of having a non-accidental injury

Country: Australia, New Zealand and Canada

Setting: PICU

\section{Therapeutic cooling}

Number of participants: 24

Method of cooling: servo-controlled cooling blanket. Iced IV bolus fluids (if indicated clinically), crushed ice to exposed surfaces, and a second cooling blanket above the child could also be used during induction

Target temperature: 32 to $33^{\circ} \mathrm{C}$

Time of cooling: No time given however randomisation had to be within 6 hours

Duration of cooling: $\leq 72$ hours

Rewarming details: no faster than $0.5^{\circ} \mathrm{C}$ every 3 hours but guided primarily by physiology rather than time. Rewarming slowed or stopped if hypotension or intracranial hypotension were not controlled

Site of temperature measurement: oesophageal

\section{No cooling}

Number of participants: 26

Method of temperature management: participants randomised to normothermia were maintained at 36 to $37^{\circ} \mathrm{C}$

Target temperature: 36 to $37^{\circ} \mathrm{C}$

Outcomes

Outcomes measured in study: paediatric cerebral performance category, eligibility and recruitment rates, protocol violations, major adverse events, ICP and CCP during first 5 days, duration of mechanical ventilation, length of stay in PICU and hospital, adverse events including infectious complications (ventilator-associated pneumonia, bacteraemia, cerebral abscess, meningitis, and urinary tract infection), bleeding, pancreatitis, acute respiratory distress syndrome, and arrhythmias (excluding sinus bradycardia), 'bad outcome' and mortality (reported at 12 months)

Notes

Funding/declarations of interest: supported, in part, by grants from the Victorian Transport Accident Commission, the Neuro-trauma Research Programme of the Western Australian Institute for Medical Research, and the Intensive Care Foundation of Australia and New Zealand. 
Study dates: November 2006 to May 2010; interruption to recruitment in 2008 due to publication of another study for 2 to 6 months

Note: data given for 'bad outcome' using a different scoring system but this is comparable to GOS and therefore we have included it

\section{Risk of bias}

\begin{tabular}{|c|c|c|}
\hline Bias & Authors' judgement & Support for judgement \\
\hline $\begin{array}{l}\text { Random sequence genera- } \\
\text { tion (selection bias) }\end{array}$ & Low risk & $\begin{array}{l}\text { "Randomization was in variable block sizes and was performed by telephone } \\
\text { at the co-ordinating center" }\end{array}$ \\
\hline $\begin{array}{l}\text { Allocation concealment } \\
\text { (selection bias) }\end{array}$ & Low risk & "Sequentially numbered opaque envelopes were used" \\
\hline $\begin{array}{l}\text { Blinding of participants } \\
\text { and personnel (perfor- } \\
\text { mance bias): mortality }\end{array}$ & Low risk & Lack of blinding unlikely to influence performance for this outcome \\
\hline $\begin{array}{l}\text { Blinding of participants } \\
\text { and personnel (perfor- } \\
\text { mance bias): GOS }\end{array}$ & Unclear risk & Unclear if lack of blinding would influence performance for this outcome \\
\hline $\begin{array}{l}\text { Blinding of participants } \\
\text { and personnel (perfor- } \\
\text { mance bias): pneumonia }\end{array}$ & Unclear risk & Unclear if lack of blinding would influence performance for this outcome \\
\hline $\begin{array}{l}\text { Blinding of outcome as- } \\
\text { sessment (detection bias): } \\
\text { mortality; pneumonia }\end{array}$ & Low risk & No details; lack of blinding unlikely to influence outcome data \\
\hline $\begin{array}{l}\text { Blinding of outcome as- } \\
\text { sessment (detection bias): } \\
\text { GOS }\end{array}$ & Unclear risk & No details \\
\hline \multirow{2}{*}{$\begin{array}{l}\text { Incomplete outcome data } \\
\text { (attrition bias) } \\
\text { All outcomes }\end{array}$} & High risk & $\begin{array}{l}\text { "There were five major protocol violations (9\%), four of which occurred in chil- } \\
\text { dren randomised to hypothermia" }\end{array}$ \\
\hline & & $\begin{array}{l}55 \text { participants recruited but data only reported for } 50 \text { due to protocol viola- } \\
\text { tions. However this was unevenly spread between groups and reasons for vio- } \\
\text { lations are reported }\end{array}$ \\
\hline $\begin{array}{l}\text { Selective reporting (re- } \\
\text { porting bias) }\end{array}$ & Low risk & $\begin{array}{l}\text { Prospectively registered study (NCT00282269). Reported outcomes are as stat- } \\
\text { ed in protocol }\end{array}$ \\
\hline Other bias & Low risk & No other sources of bias identified \\
\hline
\end{tabular}

Biswas 2002

\begin{tabular}{ll}
\hline Methods & Randomised controlled trial, parallel group \\
\hline Participants & Total number of participants: 21 \\
& Baseline characteristics: \\
& Therapeutic cooling
\end{tabular}


Biswas 2002 (Continued)

\author{
Age: mean (SD) $5.9( \pm 2.9)$ years \\ Type of injury (closed/open): closed \\ GCS on admission: mean (SD) 4.7 ( \pm 1.9$)$
}

\title{
No cooling
}

Age: mean (SD) $6.5( \pm 3.7)$ years

Type of injury (closed/open): closed

GCS on admission: mean (SD) 5.6 ( \pm 1.8$)$

Inclusion criteria: children $\leq 18$ years of age who presented with an admission GCS $<8$ and admitted to the paediatric ICU within 6 hours of injury

Exclusion criteria: GCS 8, evidence of clinical brain death, history of cardiopulmonary arrest at scene or on admission, existing ventriculoperitoneal or ventriculoatrial shunts, marked haemodynamic instability, or admission 6 hours after time of injury, children with significant intra-abdominal pathology or bleeding diathesis

Country: USA

Setting: PICU

\section{Therapeutic cooling}

Number of participants: 10

Method of cooling: all participants had cooling blanket placed underneath them

Target temperature: 32 to $34^{\circ} \mathrm{C}$

Time of cooling: immediately after enrolment over 4 hour period

Duration of cooling: 48 hours

Rewarming details: over 12 hours, not exceeding $1^{\circ} \mathrm{C}$ per hour

Site of measurement: rectal

\section{No cooling}

Number of participants: 11

Method of temperature management: all participants had cooling blanket placed underneath them Target temperature: 36.5 to $37.5^{\circ} \mathrm{C}$

\section{Outcomes}

Outcomes measured in study: mortality (during study period; see note below), GOS (at 3, 6, 12 months), measurements of ICP, cerebral perfusion pressure, MAP, daily cerebral physiologic data, lactate-oxygen index

Notes

Funding/declarations of interest : supported, in part, by Cook Critical Care, Bloomington, IN (jugular bulb catheters) and Codman, Johnson \& Johnson Professional, Raynham, MA (intracranial pressure monitors)

\section{Study dates: March 1998 to April 1999}

Note: 2 participants excluded from later data analysis due to death in first 24 hours. These participants were included in this review for the mortality outcome

\section{Risk of bias}


Biswas 2002 (Continued)

\section{Bias Authors'judgement Support for judgement}

Random sequence genera- Unclear risk tion (selection bias)

"After enrollment the children were randomised to either normothermia or hypothermia group"

No additional details

\begin{tabular}{lll}
\hline $\begin{array}{l}\text { Allocation concealment } \\
\text { (selection bias) }\end{array}$ & Unclear risk & No details \\
\hline $\begin{array}{l}\text { Blinding of participants } \\
\text { and personnel (perfor- } \\
\text { mance bias): mortality }\end{array}$ & Low risk & Lack of blinding unlikely to influence performance for this outcome \\
\hline $\begin{array}{l}\text { Blinding of participants } \\
\text { and personnel (perfor- } \\
\text { mance bias): GOS }\end{array}$ & Unclear risk & Unclear if lack of blinding would influence performance for this outcome \\
\hline
\end{tabular}

Blinding of outcome as-
sessment (detection bias):

mortality; pneumonia

$\begin{array}{ll}\begin{array}{l}\text { Blinding of outcome as- } \\ \text { sessment (detection bias): }\end{array} & \text { Low risk }\end{array} \quad \begin{aligned} & \text { Clinical nurse research co-ordinator who was blinded to the patients treat- } \\ & \text { ment arm performed the evaluation and scoring" }\end{aligned}$
GOS

\begin{tabular}{lll}
\hline $\begin{array}{l}\text { Incomplete outcome data } \\
\text { (attrition bias) } \\
\text { All outcomes }\end{array}$ & Low risk & $\begin{array}{l}\text { Two participants were excluded from later analysis due to death within } 24 \\
\text { hours, but possible to include these for the primary outcome }\end{array}$ \\
\hline $\begin{array}{l}\text { Selective reporting (re- } \\
\text { porting bias) }\end{array}$ & Unclear risk & $\begin{array}{l}\text { Clinical trials registration or pre-published protocol not reported. Insufficient } \\
\text { information to make judgement }\end{array}$ \\
\hline Other bias & Unclear risk & $\begin{array}{l}\text { "There were a greater number of patients with Glasgow Coma Scale of } 3 \text { in the } \\
\text { hypothermia group" }\end{array}$ \\
& Unclear if this may have influenced the results \\
\hline
\end{tabular}

\section{Chen 2001}

\begin{tabular}{ll}
\hline Methods & Randomised controlled trial, parallel group \\
\hline Participants & Total number of participants: 60 \\
& Baseline characteristics: \\
& Therapeutic cooling \\
& Age: 34.1 years (does not state if mean/median) \\
& Gender M/F: $24 / 6$ \\
& Type of injury (closed/open): closed \\
& GCS on admission: 5.01 (does not state if mean/median) \\
No cooling \\
Age: 33.2 years (does not state if mean/median)
\end{tabular}


Chen 2001 (Continued)

Gender M/F: 23/7

Type of injury (closed/open): closed

GCS on admission: 4.98 (does not state if mean/median)

Inclusion criteria: 18 to 60 years of age, closed head injury with GCS averaging 3 to 8 , within 6 hours of injury

Exclusion criteria: pregnant or breastfeeding women, patients with severe organic disease, psychonosema and hormone-sensitive history

Country: China

Setting: hospital

Therapeutic cooling

Number of participants: 30

Method of cooling: semiconductor cooling blankets, high-dose barbiturates

Target temperature: 33 to $35^{\circ} \mathrm{C}$

Time of cooling: immediately

Duration of cooling: 3 to 10 days, until ICP reduced to normal level for 24 hours

Rewarming details: not reported

Site of measurement: not reported

\section{No cooling}

Number of participants: 30

Method of temperature management: not reported

Target temperature: not reported

\begin{tabular}{ll}
\hline Outcomes & $\begin{array}{l}\text { Outcomes measured in study: mortality, living qualities of survivors and neurobiochemical indexes, GOS } \\
\text { at } 3 \text { to } 6 \text { months }\end{array}$ \\
\hline Notes & Funding/declarations of interest: not reported \\
& Study dates: September 1997 to January 1999 \\
\hline
\end{tabular}

\section{Risk of bias}

\begin{tabular}{lll}
\hline Bias & Authors' judgement & Support for judgement \\
\hline $\begin{array}{l}\text { Random sequence genera- } \\
\text { tion (selection bias) }\end{array}$ & Unclear risk & Participants were randomly divided into groups; no additional details \\
\hline $\begin{array}{l}\text { Allocation concealment } \\
\text { (selection bias) }\end{array}$ & Unclear risk & No details \\
\hline $\begin{array}{l}\text { Blinding of participants } \\
\text { and personnel (perfor- } \\
\text { mance bias): } \text { mortality }\end{array}$ & Low risk & No details; lack of blinding unlikely to influence performance \\
\hline
\end{tabular}


Chen 2001 (Continued)
Blinding of outcome as-
Low risk
No details; lack of blinding unlikely to influence results sessment (detection bias): mortality; pneumonia

Incomplete outcome data Low risk No apparent losses
(attrition bias)
All outcomes

\begin{tabular}{lll}
\hline $\begin{array}{l}\text { Selective reporting (re- } \\
\text { porting bias) }\end{array}$ & Unclear risk & $\begin{array}{l}\text { Clinical trials registration or pre-published protocol not reported. Insufficient } \\
\text { information to make judgement }\end{array}$ \\
\hline Other bias & Unclear risk & Limited detail in paper; not possible to judge if any other sources of bias \\
\hline
\end{tabular}

Clifton 1992

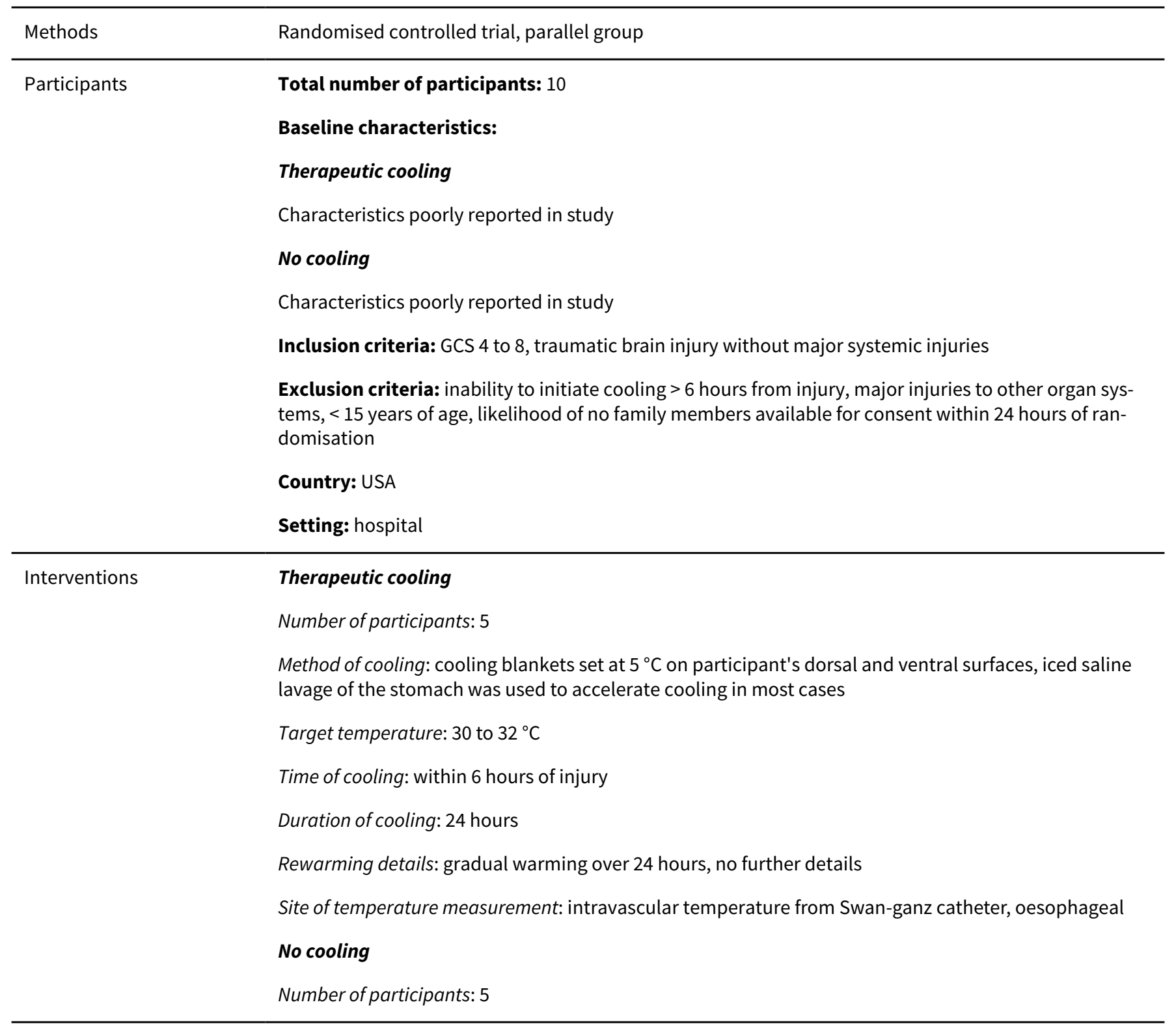


Clifton 1992 (Continued)

Outcomes Outcomes measured in study: GOS at 3 months (to include mortality at 3 months), complications

Funding/declarations of interest: no details
Study dates: not reported
Note: reported two studies in one paper. One study reported participants undergoing elective cranioto-
my and one study reported participants with severe brain injury. We only included data for participants
from the brain injury group

\section{Risk of bias}

\begin{tabular}{|c|c|c|}
\hline Bias & Authors' judgement & Support for judgement \\
\hline $\begin{array}{l}\text { Random sequence genera- } \\
\text { tion (selection bias) }\end{array}$ & Unclear risk & $\begin{array}{l}\text { Participants randomised to groups and groups stratified by GCS scale; no addi- } \\
\text { tional details of methods used for randomisation }\end{array}$ \\
\hline $\begin{array}{l}\text { Allocation concealment } \\
\text { (selection bias) }\end{array}$ & Unclear risk & No details \\
\hline $\begin{array}{l}\text { Blinding of participants } \\
\text { and personnel (perfor- } \\
\text { mance bias): mortality }\end{array}$ & Low risk & Lack of blinding unlikely to influence performance for this outcome \\
\hline $\begin{array}{l}\text { Blinding of participants } \\
\text { and personnel (perfor- } \\
\text { mance bias): GOS }\end{array}$ & Unclear risk & Unclear if lack of blinding would influence performance for this outcome \\
\hline $\begin{array}{l}\text { Blinding of participants } \\
\text { and personnel (perfor- } \\
\text { mance bias): pneumonia }\end{array}$ & Unclear risk & Unclear if lack of blinding would influence performance for this outcome \\
\hline $\begin{array}{l}\text { Blinding of outcome as- } \\
\text { sessment (detection bias): } \\
\text { mortality; pneumonia }\end{array}$ & Low risk & $\begin{array}{l}\text { Not stated. However, a lack of blinding is unlikely to influence mortality and } \\
\text { pneumonia outcomes }\end{array}$ \\
\hline $\begin{array}{l}\text { Blinding of outcome as- } \\
\text { sessment (detection bias): } \\
\text { GOS }\end{array}$ & Unclear risk & Lack of blinding could influence assessment of GOS \\
\hline $\begin{array}{l}\text { Incomplete outcome data } \\
\text { (attrition bias) } \\
\text { All outcomes }\end{array}$ & Low risk & $\begin{array}{l}\text { Severe brain injury section of the study: primary outcome ( } 3 \text { month GOS) re- } \\
\text { ported data for all participants }(n=10) \text { in the first series. Data from second se- } \\
\text { ries not available at time of report }\end{array}$ \\
\hline $\begin{array}{l}\text { Selective reporting (re- } \\
\text { porting bias) }\end{array}$ & Unclear risk & $\begin{array}{l}\text { Clinical trials registration or pre-published protocol not reported. Insufficient } \\
\text { information to make judgement }\end{array}$ \\
\hline Other bias & Low risk & No other sources of bias identified \\
\hline
\end{tabular}

Clifton 1993

Methods Randomised controlled trial, parallel group

Participants

\section{Total number of participants: 46}

Baseline characteristics: 
Clifton 1993 (Continued)

\section{Therapeutic cooling}

Age and GCS on admission reported as not statistically significantly different between groups

\section{No cooling}

Age and GCS on admission reported as not statistically significantly different between groups

Inclusion criteria: 16 to 60 years of age, post-resuscitation GCS 4 to 7 after non-penetrating brain injury

Exclusion criteria: hypoxia, major systemic injuries requiring laparotomy, pulmonary failure, sustained hypotension; or if cooling could not be initiated within 6 hours of injury

Country: USA

Setting: hospital

Therapeutic cooling
Number of participants: 24
Method of cooling: securely wrapping the participant in cooling blankets set
Target temperature: $33^{\circ} \mathrm{C}$
Time of cooling: within 6 hours
Duration of cooling: 48 hours
Rewarming details: 48 hours after a temperature of $33^{\circ} \mathrm{C}$ was first reached,
every 4 hours
Site of temperature measurement: intravascular temperatures from the Swa
No cooling
Number of participants: 22
Method of temperature management: cooling blankets and acetaminophen
Target temperature: $37^{\circ} \mathrm{C}$
Time of cooling: within 6 hours
Duration of cooling: 80 hours after injury
Site of temperature measurement: bladder or rectal

Outcomes

Outcomes measured in study: physiological measurements (heart rate, MAP, ICP, CPP), coagulation parameters (PT, PTT), electrolytes, GOS, complications (to include pneumonia), mortality

Notes

Funding/declarations of interest: no details

Study dates: not reported

\section{Risk of bias}

\begin{tabular}{lll}
\hline Bias & Authors' judgement & Support for judgement \\
\hline $\begin{array}{l}\text { Random sequence genera- } \\
\text { tion (selection bias) }\end{array}$ & Unclear risk & $\begin{array}{l}\text { Described as randomised, stratified into two groups: GCS 4 and 5; and GCS 6 } \\
\text { and 7. No additional details of randomisation process }\end{array}$ \\
\hline $\begin{array}{l}\text { Allocation concealment } \\
\text { (selection bias) }\end{array}$ & Unclear risk & No details \\
\hline
\end{tabular}


Clifton 1993 (Continued)

Blinding of participants Low risk Lack of blinding would be unlikely to influence performance and personnel (performance bias): mortality

Blinding of participants Unclear risk Unclear if lack of blinding would influence performance
and personnel (perfor-
mance bias): GOS

\begin{tabular}{lll}
\hline $\begin{array}{l}\text { Blinding of participants } \\
\text { and personnel (perfor- } \\
\text { mance bias): pneumonia }\end{array}$ & Unclear risk & Unclear if lack of blinding would influence performance \\
\hline $\begin{array}{l}\text { Blinding of outcome as- } \\
\text { sessment (detection bias): } \\
\text { mortality; pneumonia }\end{array}$ & Low risk & Lack of blinding unlikely to influence outcome assessment \\
\hline $\begin{array}{l}\text { Blinding of outcome as- } \\
\text { sessment (detection bias): } \\
\text { GOS }\end{array}$ & Low risk & GOS assessed by neuropsychologist blinded to treatment assignment \\
\hline $\begin{array}{l}\text { Incomplete outcome data } \\
\text { (attrition bias) } \\
\text { All outcomes }\end{array}$ & Low risk & $\begin{array}{l}\text { Possible loss of 1 participant to GOS assessment (in hypothermia group) - un- } \\
\text { clearly reported. Otherwise data appears complete }\end{array}$ \\
\hline $\begin{array}{l}\text { Selective reporting (re- } \\
\text { porting bias) }\end{array}$ & Unclear risk & $\begin{array}{l}\text { Clinical trials registration or pre-published protocol not reported. Insufficient } \\
\text { information to make judgement }\end{array}$ \\
\hline \begin{tabular}{l} 
Other bias \\
\hline
\end{tabular} & Low risk & No other sources of bias identified \\
\hline
\end{tabular}

Clifton 2001

Methods Randomised controlled trial, parallel group

Participants

Total number of participants: 392

\section{Baseline characteristics:}

\section{Therapeutic cooling}

Age: mean (SD) $31( \pm 12)$ years

Type of injury (closed/open): closed

GCS on admission: mean (SD) $50.6( \pm 1.3)$

\section{No cooling}

Age: mean (SD) $32( \pm 13)$ years

Type of injury (closed/open): closed

GCS on admission: mean (SD) 5.8 ( \pm 1.3 )

Inclusion criteria: 16 to 65 years of age, non-penetrating head injury, GCS 3 to 8 after resuscitation

Exclusion criteria: GCS score of 3 with unreactive pupils, life-threatening injury to an organ other than the brain, systolic blood pressure of $<90 \mathrm{mmHg}$ after resuscitation, oxygen saturation $<94 \%$ after resuscitation, bleeding, pregnancy, known pre-existing medical conditions (e.g. severe heart disease) or if examiners unable to initiate cooling within 6 hours after injury 
Clifton 2001 (Continued)

\section{Country: USA}

Setting: 11 centres, hospital (associated abstract states 9 centres)

Interventions

Therapeutic cooling

Number of participants: 199

Method of cooling: cooling procedures included application of ice, gastric lavage with iced fluids, use of room temperature air in the ventilator circuit. Temperature control pads incorporated into a kinetic treatment tables used to maintain temperature once reached

Target temperature: 32.5 to $34^{\circ} \mathrm{C}$

Time of cooling: within 6 hours after injury

Duration of cooling: 48 hours

Rewarming details: rate $\geq 0.5^{\circ} \mathrm{C}$ per 2 hour period

Site of temperature measurement: urinary bladder with use of Foley catheters with thermisters

\section{No cooling}

Number of participants: 193

Target temperature: $37^{\circ} \mathrm{C}$

Outcomes Outcomes measured in study: GOS at 6 months (to include mortality data at 6 months), time to reach target body temperature, MAP, ICP, therapy intensity level

Notes

Funding/declarations of interest: supported by grants from the National Institute of Neurological Disorders and Stroke and from Kinetic Concept (San Antonio, Texas)

Study dates: October 1994 to May 1998

\section{Risk of bias}

\begin{tabular}{|c|c|c|}
\hline Bias & Authors' judgement & Support for judgement \\
\hline $\begin{array}{l}\text { Random sequence genera- } \\
\text { tion (selection bias) }\end{array}$ & Unclear risk & Described as randomised but no additional details \\
\hline $\begin{array}{l}\text { Allocation concealment } \\
\text { (selection bias) }\end{array}$ & Unclear risk & No details \\
\hline $\begin{array}{l}\text { Blinding of participants } \\
\text { and personnel (perfor- } \\
\text { mance bias): mortality }\end{array}$ & Low risk & Lack of blinding would be unlikely to influence performance \\
\hline $\begin{array}{l}\text { Blinding of participants } \\
\text { and personnel (perfor- } \\
\text { mance bias): GOS }\end{array}$ & Unclear risk & Unclear if lack of blinding would influence performance \\
\hline $\begin{array}{l}\text { Blinding of outcome as- } \\
\text { sessment (detection bias): } \\
\text { mortality; pneumonia }\end{array}$ & Low risk & $\begin{array}{l}\text { "Glasgow Outcome Scale was conducted } 6 \text { months after the injury by examin- } \\
\text { ers who were unaware of the patients' treatment group assignments. Data on } \\
\text { acute care and outcomes were transmitted to the Biostatistics Center at the } \\
\text { Medical College of Virginia. Only the study biostatistician was aware of each } \\
\text { patient's treatment group assignment but the patient safety and monitoring } \\
\text { board had access to data grouped according to treatment" }\end{array}$ \\
\hline
\end{tabular}


Clifton 2001 (Continued)

Blinding of outcome as- Low risk "Glasgow Outcome Scale was conducted 6 months after the injury by examinsessment (detection bias): ers who were unaware of the patients' treatment group assignments. Data on acute care and outcomes were transmitted to the Biostatistics Center at the Medical College of Virginia. Only the study biostatistician was aware of each patient's treatment group assignment but the patient safety and monitoring board had access to data grouped according to treatment"

Incomplete outcome data Low risk (attrition bias)

"Outcome data were obtained for 385 patients (98\%). However, data on age or All outcomes Glasgow coma score were missing or inaccurate for 17 patients, and therefore outcome data adjusted for age and Glasgow coma score were analysed for 368 patients."

Loss of data reported unlikely to affect data - low percentage loss

\begin{tabular}{lll}
\hline $\begin{array}{l}\text { Selective reporting (re- } \\
\text { porting bias) }\end{array}$ & Unclear risk & $\begin{array}{l}\text { Clinical trials registration or pre-published protocol not reported. Insufficient } \\
\text { information to make judgement }\end{array}$
\end{tabular}

Other bias Low risk No other sources of bias identified

Clifton 2011

\begin{tabular}{ll}
\hline Methods & Randomised controlled trial, parallel design \\
\hline
\end{tabular}

Participants

Total number of participants: 97

Baseline characteristics:

Therapeutic cooling

Age: mean (SD) $26( \pm 9)$ years

Type of injury (closed/open): closed

GCS on admission: score 5 to $8: 33 / 52$; score 3 to $4: 19 / 52$

\section{No cooling}

Age: mean (SD) $31( \pm 11)$ years

Type of injury (closed/open): closed

GCS on admission: score 5 to $8: 22 / 45$; score 3 to $4: 23 / 45$

Inclusion criteria: 16 to 45 years of age, non-penetrating brain injury, not responsive to instructions, GCS 3 to 8 after resuscitation without life-threatening associated injuries

Exclusion criteria: at randomisation: suspected pregnancy, systolic blood pressure $<110 \mathrm{mmHg}$, diastolic blood pressure $<60 \mathrm{mmHg}$, sustained heart rate $>120$ beats per minute, or if they could not be reached by study-affiliated personnel within 2 to 5 hours of injury. After assessment and resuscitation: GCS of 3 with non reactive pupils, GCS 7 to 8 with normal CT scan, inability to measure an accurate GCS score, abbreviated injury severity score of 4 or greater for organs other than the brain, $\mathrm{SBP}<110$ $\mathrm{mmHg}, \mathrm{DBP}<60 \mathrm{mmHg}$, persistent hypoxia, or a positive pregnancy test

Country: USA and Canada

Setting: participants enrolled during transport to hospital or in emergency department, care then in specialist brain injury setting 
Clifton 2011 (Continued)

\section{Number of participants: 52}

Method of cooling: initial cooling to $35^{\circ} \mathrm{C}$ by infusion of $2 \mathrm{~L}$ of cold IV fluid and use of wet sheets. Subseuqent cooling after full assessment using surface cooling, cold IV fluids and cold gastric lavage to 33

${ }^{\circ} \mathrm{C}$ and maintained for 48 hours

Target temperature: $33^{\circ} \mathrm{C}$

Time of cooling: stage 1 immediate; stage 2 after full assessment

Duration of cooling: initial cooling plus 48 hours of maintenance

Rewarming details: $0.5^{\circ} \mathrm{C}$ every 2 hours, regardless of levels of ICP

Site of temperature measurement: bladder

\section{No cooling}

Number of participants: 45

Method of temperature management: none - although temperatures above $38^{\circ} \mathrm{C}$ were managed with paracetamol and cooling blankets

Target temperature: $37^{\circ} \mathrm{C}$

Outcomes Outcomes measured in study: GOS at 6 months adjusted for baseline age and GCS, 58 separate complications

Notes

Funding/declarations of interest: National Institute of Neurological Disorders and Stroke. Sponsor had no role in data collection, analysis and interpretation, but was involved in study design and choosing timing of interim analysis

Study dates: December 2005 to June 2009

\section{Risk of bias}

\begin{tabular}{lll}
\hline Bias & Authors' judgement & Support for judgement \\
\hline $\begin{array}{l}\text { Random sequence genera- } \\
\text { tion (selection bias) }\end{array}$ & Low risk & Generated with random number generator by study biostatistician \\
\hline $\begin{array}{l}\text { Allocation concealment } \\
\text { (selection bias) }\end{array}$ & Low risk & $\begin{array}{l}\text { Secretary at trial co-ordinating centre placed treatment assignments into } \\
\text { numbered opaque envelopes, which were sealed and mailed to each trial cen- } \\
\text { tre. Randomisation was done at each centre by study nurses after opening se- } \\
\text { quentially numbered envelopes }\end{array}$
\end{tabular}

\begin{tabular}{lll}
\hline $\begin{array}{l}\text { Blinding of participants } \\
\text { and personnel (perfor- } \\
\text { mance bias): mortality }\end{array}$ & Low risk & Personnel were aware of group assignment; unlikely to influence performance \\
\hline $\begin{array}{l}\text { Blinding of participants } \\
\begin{array}{l}\text { and personnel (perfor- } \\
\text { mance bias): GOS }\end{array}\end{array}$ & Unclear risk & $\begin{array}{l}\text { Personnel were aware of group assignment; unclear if this could influence per- } \\
\text { formance }\end{array}$ \\
\hline
\end{tabular}

\begin{tabular}{|c|c|c|}
\hline $\begin{array}{l}\text { Blinding of outcome as- } \\
\text { sessment (detection bias): } \\
\text { mortality; pneumonia }\end{array}$ & Low risk & $\begin{array}{l}\text { "Investigators who assessed the outcome measures were masked to treat- } \\
\text { ment allocation" }\end{array}$ \\
\hline
\end{tabular}

\begin{tabular}{|c|c|c|}
\hline $\begin{array}{l}\text { Blinding of outcome as- } \\
\text { sessment (detection bias): } \\
\text { GOS }\end{array}$ & Low risk & $\begin{array}{l}\text { "Investigators who assessed the outcome measures were masked to treat- } \\
\text { ment allocation" }\end{array}$ \\
\hline
\end{tabular}


Clifton 2011 (Continued)

Incomplete outcome data Low risk 6 month outcome data were not available for 8/97 participants, and were im(attrition bias) puted from earlier 3 month $(n=6), 4$ week $(n=1)$ or 2 week $(n=1)$ data. The

All outcomes study authors state they conducted a sensitivity analysis using complete outcome data and results were the same

Selective reporting (re- Unclear risk
porting bias)

Prospective trial registration (NCT00178711). Published study reports data for complications but these are not listed as outcome measures in the trial registration documents. (Also reports on medical interventions, and laboratory data. Trial registration lists secondary outcomes, GOS up to 12 months and neurological assessments, which are not reported in the published study)

Other bias Unclear risk

Some differences in GCS at baseline, and participants in normothermia group were older $(P=0.03)$. However, it was unclear if these differences were likely to influence results

Harris 2009

Methods Randomised controlled trial, parallel group

Participants

Total number of participants: 25

\section{Baseline characteristics:}

\section{Therapeutic cooling}

Age: mean (SD) $38.1( \pm 15.0)$ years

Gender M/F: 11/1

GCS on admission: mean (SD) $3.9( \pm 1.7)$

Type of injury (closed/open): blunt 10; penetrating 2

\section{No cooling}

Age: mean (SD) $33.2( \pm 20.0)$

Gender M/F: 11/2

GCS on admission: mean (SD) $4.3( \pm 2.1)$

Type of injury (closed/open): blunt 12; penetrating 1

Inclusion criteria: severe traumatic brain injury, GCS score $\leq 8, \geq 18$ years of age, required an ICP monitor and Foley catheter as part of routine treatment, able to receive the Discrete Cerebral Hypothermia cooling cap within 48 hours of hospital admission, participant's family member or guardian spoke English to ensure proper informed consent

Exclusion criteria: patient's family member or guardian was unwilling or unable to sign an informed consent, physical placement of the cooling cap impeded routine treatment, patient's core body temperature was $\leq 36^{\circ} \mathrm{C}$ at the time of initial assessment, treatment could not be initiated within 48 hours of admission

Country: USA

Setting: Level 1 trauma centre, hospital

\footnotetext{
Interventions
}

\section{Therapeutic cooling}

Number of participants: 12 
Target temperature: target intracranial temperature $33^{\circ} \mathrm{C}$, target systemic temperature maintained above $36^{\circ} \mathrm{C}$ using heating blankets

Time of cooling: mean time in emergency department prior to study enrolment $4.6( \pm 4.5)$ hours. (Note: exclusion criteria suggests could be up to 48 hours after admission)

Duration of cooling: 24 hours

Rewarming details: $0.5^{\circ} \mathrm{C}$ every 3 hours for 24 hours (study hours 25 to 48 ). Cooling cap was removed after 48 hours.

Site of measurement: intracranial and bladder temperatures

\section{No cooling}

Number of participants: 13

Method of temperature management: heating blankets

Target temperature: $36^{\circ} \mathrm{C}$

Time of cooling: mean time in emergency department prior to study enrolment $7.2( \pm 3.7)$ hours

Outcomes

Outcomes measured in study: temperature gradient, mortality (up to day 28), GOS (up to day 28), Functional Independence Measure, complications (respiratory failure, shock, septicaemia, decubitus ulcer, cardiac arrest)

Notes Funding/declarations of interest: "no conflict of interest concerning the materials or methods used in this study or the findings specified in this paper"

Study dates: July 2006 to August 2007

Note: unfavourable outcome was reported as median maximum change in GOS during 28 study period.

"No statistically significant intergroup difference in GOS-determined morbidity"

\section{Risk of bias}

Bias Authors' judgement Support for judgement

\begin{tabular}{|c|c|c|}
\hline $\begin{array}{l}\text { Random sequence genera- } \\
\text { tion (selection bias) }\end{array}$ & Low risk & $\begin{array}{l}\text { "The randomisation was determined by the Department of Biostatistics using } \\
\text { computer-generated random numbers" }\end{array}$ \\
\hline & & Participants stratified by GCS scores after randomisation \\
\hline
\end{tabular}

\begin{tabular}{lll}
\hline $\begin{array}{l}\text { Allocation concealment } \\
\text { (selection bias) }\end{array}$ & Unclear risk & No details \\
\hline $\begin{array}{l}\text { Blinding of participants } \\
\text { and personnel (perfor- } \\
\text { mance bias): mortality }\end{array}$ & Low risk & Lack of blinding unlikely to influence performance for this outcome \\
\hline $\begin{array}{l}\text { Blinding of participants } \\
\text { and personnel (perfor- } \\
\text { mance bias): GOS }\end{array}$ & Unclear risk & Unclear if lack of blinding would influence performance for this outcome \\
\hline $\begin{array}{l}\text { Blinding of outcome as- } \\
\text { sessment (detection bias): } \\
\text { mortality; pneumonia }\end{array}$ & Low risk & $\begin{array}{l}\text { No details; lack of outcome assessor blinding is unlikely to influence outcome } \\
\text { data }\end{array}$ \\
\hline
\end{tabular}


Harris 2009 (Continued)

Blinding of outcome as- Unclear risk No details sessment (detection bias): GOS

\begin{tabular}{lll}
\hline $\begin{array}{l}\text { Incomplete outcome data } \\
\text { (attrition bias) } \\
\text { All outcomes }\end{array}$ & High risk & $\begin{array}{l}\text { Complete outcome data not available for 4 participants, and study has small } \\
\text { sample size. Explanations given and patients still included in intention-to-treat } \\
\text { analysis. Control group has a 23\% loss }\end{array}$ \\
\hline $\begin{array}{l}\text { Selective reporting (re- } \\
\text { porting bias) }\end{array}$ & Unclear risk & $\begin{array}{l}\text { Clinical trials registration or pre-published protocol not reported. Insufficient } \\
\text { information to make judgement }\end{array}$ \\
\hline Other bias & Unclear risk & $\begin{array}{l}\text { Baseline characteristics comparable. But statistically significant differences in } \\
\text { time to study enrolment between two groups }\end{array}$ \\
\hline
\end{tabular}

Hashiguchi 2003

\begin{tabular}{|c|c|}
\hline Methods & Randomised controlled trial, parallel group \\
\hline \multirow[t]{16}{*}{ Participants } & Total number of participants: 17 \\
\hline & Baseline characteristics: \\
\hline & Therapeutic cooling \\
\hline & Age: mean $(\mathrm{SD}) 29.0( \pm 14.9)$ years \\
\hline & $\begin{array}{l}\text { Type of injury (closed/open): not clearly reported but baseline data reports participant conditions as: } \\
\text { skull base fracture, contusion, epidural haematoma, intracerebral haematoma, subarachnoid haemor- } \\
\text { rhage, subdural haematoma }\end{array}$ \\
\hline & Gender M/F: 9/0 \\
\hline & GCS on admission: mean (SD) $5.4( \pm 1.7)$ \\
\hline & No cooling \\
\hline & Age: mean (SD) $39.1( \pm 13.2)$ years \\
\hline & Type of injury (closed/open): as above \\
\hline & Gender M/F: 5/3 \\
\hline & GCS on admission: mean (SD) $5.4( \pm 2.0)$ \\
\hline & $\begin{array}{l}\text { Inclusion criteria: severely head injured patients who required continued infusion of barbiturartes to } \\
\text { control intracranial hypotension }\end{array}$ \\
\hline & Exclusion criteria: $<10$ years of age, severe life threatening injury to another organ \\
\hline & Country: Japan \\
\hline & Setting: hospital \\
\hline
\end{tabular}

Interventions

\section{Therapeutic cooling}

Number of participants: 9

Method of cooling: surface cooling, water-circulating blankets above and below participant

Target temperature: $34^{\circ} \mathrm{C}$ 
Hashiguchi 2003 (Continued)

Time of cooling: deferred until ICP stabilized below $20 \mathrm{mmHg}$ using high dose barbiturate therapy and then cooling started as quickly as possible

Duration of cooling: 48 hours

Rewarming details: approximately $1^{\circ} \mathrm{C}$ per day using barbiturates for 5 days. Aim of $37^{\circ} \mathrm{C}$ by day 5 . After day 5 maintained at 37.5 to $38.5^{\circ} \mathrm{C}$ by surface cooling

Site of temperature measurement: intracranial

\section{No cooling}

Number of participants: 8

Target temperature: 36.5 to $37.5^{\circ} \mathrm{C}$

Method of temperature management: surface cooling, water-circulating blankets

Duration of temperature management: 5 days

Outcomes Outcomes measured in study: expression of heat shock proteins in leukocytes, infectious complications
within 1 week (to include pneumonia), GCS at 6 months (to include mortality data)

Notes $\quad$ Funding/declarations of interest: supported by Research on Brain Science grant from Ministry of Health and Welfare of Japan, and a grant from the Marine and Fire Insurance Association of Japan, Inc

Study dates: September 1997 to November 1999

\section{Risk of bias}

Bias Authors' judgement Support for judgement

Random sequence genera- Unclear risk Participants randomly divided into 2 groups but no additional details tion (selection bias)

\begin{tabular}{lll}
\hline $\begin{array}{l}\text { Allocation concealment } \\
\text { (selection bias) }\end{array}$ & Unclear risk & No details \\
\hline $\begin{array}{l}\text { Blinding of participants } \\
\text { and personnel (perfor- } \\
\text { mance bias): mortality }\end{array}$ & Low risk & Lack of blinding unlikely to influence performance for this outcome \\
\hline $\begin{array}{l}\text { Blinding of participants } \\
\text { and personnel (perfor- } \\
\text { mance bias): GOS }\end{array}$ & Unclear risk & Unclear if lack of blinding would influence performance for this outcome \\
\hline $\begin{array}{l}\text { Blinding of participants } \\
\text { and personnel (perfor- } \\
\text { mance bias): pneumonia }\end{array}$ & Unclear risk & Unclear if lack of blinding would influence performance for this outcome \\
\hline $\begin{array}{l}\text { Blinding of outcome as- } \\
\text { sessment (detection bias): } \\
\text { mortality; pneumonia }\end{array}$ & Low risk & $\begin{array}{l}\text { No details; lack of outcome assessor blinding is unlikely to influence outcome } \\
\text { data }\end{array}$ \\
\hline $\begin{array}{l}\text { Blinding of outcome as- } \\
\text { sessment (detection bias): } \\
\text { GOS }\end{array}$ & Unclear risk & No details \\
\hline
\end{tabular}

Incomplete outcome data Low risk No losses
(attrition bias) 
Hashiguchi 2003 (Continued)

All outcomes

\begin{tabular}{|c|c|c|}
\hline $\begin{array}{l}\text { Selective reporting (re- } \\
\text { porting bias) }\end{array}$ & Unclear risk & $\begin{array}{l}\text { Clinical trials registration or pre-published protocol not reported. Insufficient } \\
\text { information to make judgement }\end{array}$ \\
\hline
\end{tabular}

Other bias Low risk No other sources of bias identified

Hirayama 1994

\begin{tabular}{ll}
\hline Methods & Randomised controlled trial, parallel group \\
\hline Participants & Total number of participants: 22 \\
& Baseline characteristics: \\
& Therapeutic cooling. No cooling \\
& No baseline characteristics table. Study authors state: "The age, GCS, pupillary reactivity, time of emer- \\
& gency department admission soon after admission, primary diagnosis and initial ICP levels were similar \\
in both groups" & Inclusion criteria: participants with severe traumatic brain injury (post resuscitation GCS $\leq 7$, closed \\
head injury, arrival within 2 hours of trauma, 18 to 81 years of age \\
Exclusion criteria: not stated \\
Country: Japan \\
Setting: hospital
\end{tabular}

Interventions

\section{Therapeutic cooling}

Number of participants: 12

Method of cooling: cooling blankets

Target temperature: 32 to $33^{\circ} \mathrm{C}$

Time of cooling: within 6 hours post-trauma

Duration of cooling: 48 hours

Rewarming details: $1^{\circ} \mathrm{C}$ every 4 hours

Site of measurement: not stated

\section{No cooling}

Number of participants: 10

Method of temperature management: "standard management"

Target temperature: 37 to $38^{\circ} \mathrm{C}$

Outcomes Outcomes measured in study: mortality (time point not stated), physiologic data (averaged in 24 hour blocks), GOS at 3 months

Notes

Funding/declarations of interest: not reported

Study dates: 1992, one year duration 
Hirayama 1994 (Continued)

Risk of bias

\begin{tabular}{|c|c|c|}
\hline Bias & Authors' judgement & Support for judgement \\
\hline $\begin{array}{l}\text { Random sequence genera- } \\
\text { tion (selection bias) }\end{array}$ & Unclear risk & Described as randomised but no additional details \\
\hline $\begin{array}{l}\text { Allocation concealment } \\
\text { (selection bias) }\end{array}$ & Unclear risk & No details \\
\hline $\begin{array}{l}\text { Blinding of participants } \\
\text { and personnel (perfor- } \\
\text { mance bias): mortality }\end{array}$ & Low risk & Lack of blinding unlikely to influence performance for this outcome \\
\hline $\begin{array}{l}\text { Blinding of participants } \\
\text { and personnel (perfor- } \\
\text { mance bias): GOS }\end{array}$ & Unclear risk & Unclear if lack of blinding would influence performance for this outcome \\
\hline $\begin{array}{l}\text { Blinding of outcome as- } \\
\text { sessment (detection bias): } \\
\text { mortality; pneumonia }\end{array}$ & Low risk & $\begin{array}{l}\text { No details; lack of outcome assessor blinding is unlikely to influence outcome } \\
\text { data }\end{array}$ \\
\hline $\begin{array}{l}\text { Blinding of outcome as- } \\
\text { sessment (detection bias): } \\
\text { GOS }\end{array}$ & Unclear risk & No details \\
\hline $\begin{array}{l}\text { Incomplete outcome data } \\
\text { (attrition bias) } \\
\text { All outcomes }\end{array}$ & Low risk & No apparent losses \\
\hline $\begin{array}{l}\text { Selective reporting (re- } \\
\text { porting bias) }\end{array}$ & Unclear risk & $\begin{array}{l}\text { Clinical trials registration or pre-published protocol not reported. Insufficient } \\
\text { information to make judgement }\end{array}$ \\
\hline Other bias & Low risk & No other sources of bias identified \\
\hline
\end{tabular}

Hutchison 2008

\begin{tabular}{ll}
\hline Methods $\quad$ Randomised controlled trial, parallel group \\
\hline
\end{tabular}

Participants

Total number of participants: 225

Baseline characteristics:

Therapeutic cooling

Age: mean (SD) $9.8( \pm 4.9)$ years

Weight kg: mean (SD) $39.4( \pm 21.2)$

Type of injury (closed/open): not stated. Injuries include extradural haematoma, intracerebral haematoma, cerebral oedema, midline shift, skull fracture

Gender M/F: 70/38

GCS on admission: median (IQR) 5 (4 to 6)

\section{No cooling}


Hutchison 2008 (Continued)

\author{
Age: mean (SD) $10.2( \pm 4.8)$ years \\ Weight kg: mean (SD) 40.3 ( \pm 21.1 ) \\ Type of injury (closed/open): as above \\ Gender M/F: 71/46 \\ GCS on admission: median (IQR) 5 (3 to 6)
}

Inclusion criteria: 1 to 17 years of age, had traumatic brain injury, GCS $\leq 8$ at scene of accident or in emergency room, CT scan that showed acute brain injury and need for mechanical ventilation

Exclusion criteria: patients who were screened $>8$ hours after injury as well as patients with refractory shock, suspected brain death, non-accidental injury, prolonged cardiac arrest at scene of accident, high cervical spine cord injury, severe neurodevelopmental disability before injury, brain injury due to gunshot wound, acute isolated epidural haematoma or pregnancy

\title{
Country: Canada
}

Setting: hospital

\section{Therapeutic cooling}

Number of participants: 108

Method of cooling: use of surface cooling techniques

Target temperature: mean (SD) $32.5( \pm 0.5){ }^{\circ} \mathrm{C}$

Time of cooling: after participant assessment and stabilization (study authors did not provide definition of stabilization), mean time to cooling after injury $6.3( \pm 2.3)$ hours

Duration of cooling: 24 hours

Rewarming details: temperature increase at a rate of $0.5^{\circ} \mathrm{C}$ every two hours. After rewarming, temperature maintained at $37( \pm 0.5){ }^{\circ} \mathrm{C}$ until intracranial hypertension resolved

Site of measurement: oesophageal

\section{No cooling}

Number of participants: 117

Target temperature: $37( \pm 0.5)^{\circ} \mathrm{C}$ until intracranial hypertension resolved processing, blood pressure, ICP, co-interventions, length of stay in ICU and hospital, rates of adverse events (hypotension, infection to include pneumonia, bleeding, arrthymias, electrolyte abnormalities)

Notes Funding/declarations of interest: supported by grants from Canadian Institutes of Health Research, Ontario Neurotrauma Foundation, the Rick Hansen Institute, the Hospital for Sick Children Foundation, Physicians Services Incorporated, Fonds de la Recherche en Santé du Québec, the Children's Hospital of Eastern Ontario Research Institute, and Direction de la Recherche Clinique, Assistance PubliqueHôpitaux de Paris. Dr Lacroix reports receiving consulting fees from Johnson \& Johnson

Study dates: February 1999 to October 2004

Note: includes participants with other injuries

\section{Risk of bias}

\section{Support for judgement}


Hutchison 2008 (Continued)

Random sequence genera- Low risk "Study physician randomly assigned the patient to a treatment group with the tion (selection bias) use of central telephone based system that was available 24 hours a day"

Independent statistician prepared blocks

\begin{tabular}{ll}
\hline $\begin{array}{l}\text { Allocation concealment } \\
\text { (selection bias) }\end{array}$ & "Sow risk \\
use of central telephone based system that was available 24 hours a day"
\end{tabular}

\begin{tabular}{lll}
\hline $\begin{array}{l}\text { Blinding of participants } \\
\text { and personnel (perfor- }\end{array}$ & Low risk & Lack of blinding unlikely to influence performance for this outcome \\
mance bias): mortality & \\
\hline $\begin{array}{l}\text { Blinding of participants } \\
\begin{array}{l}\text { and personnel (perfor- } \\
\text { mance bias): GOS }\end{array}\end{array}$ & Unclear risk & Unclear if lack of blinding would influence performance for this outcome \\
\hline
\end{tabular}

\begin{tabular}{|c|c|c|}
\hline $\begin{array}{l}\text { Blinding of participants } \\
\text { and personnel (perfor- } \\
\text { mance bias): pneumonia }\end{array}$ & Unclear risk & Unclear if lack of blinding would influence performance for this outcome \\
\hline $\begin{array}{l}\text { Blinding of outcome as- } \\
\text { sessment (detection bias): } \\
\text { mortality; pneumonia }\end{array}$ & Low risk & $\begin{array}{l}\text { No details; lack of outcome assessor blinding is unlikely to influence outcome } \\
\text { data }\end{array}$ \\
\hline $\begin{array}{l}\text { Blinding of outcome as- } \\
\text { sessment (detection bias): } \\
\text { GOS }\end{array}$ & Low risk & $\begin{array}{l}\text { Unfavourable outcome assessed by personnel unaware of treatment assign- } \\
\text { ments }\end{array}$ \\
\hline $\begin{array}{l}\text { Incomplete outcome data } \\
\text { (attrition bias) } \\
\text { All outcomes }\end{array}$ & High risk & $\begin{array}{l}20 \text { out of } 225 \text { participants were lost to follow-up but the numbers lost were not } \\
\text { balanced between groups ( } 6 \% \text { in hypothermia versus } 12 \% \text { in normothermic } \\
\text { groups) }\end{array}$ \\
\hline $\begin{array}{l}\text { Selective reporting (re- } \\
\text { porting bias) }\end{array}$ & Unclear risk & $\begin{array}{l}\text { Clinical trials registration (ISRCTN77393684). However retrospective registra- } \\
\text { tion which did not allow for valid comparison of outcomes between protocol } \\
\text { and final report }\end{array}$ \\
\hline Other bias & Unclear risk & $\begin{array}{l}\text { Some differences in baseline characteristics, a greater proportion had an ex- } \\
\text { tradural haematoma in the normothermic group (19\%) than in the hypother- } \\
\text { mic group ( } 9 \%) \text {. A greater proportion of participants received dopamine, epi- } \\
\text { nephrine or norepinephrine in the hypothermic groups (85\%) than in the nor- } \\
\text { mothermic group (56\%) }\end{array}$ \\
\hline
\end{tabular}

Idris 2014

\begin{tabular}{ll}
\hline Idris 2014 & Randomised controlled trial, parallel group \\
\hline Participants & Total number of participants: 23 \\
& Baseline characteristics: \\
& Therapeutic cooling \\
& Age: mean $(95 \% \mathrm{Cl}): 28.9(17.3$ to 40.5$)$ years \\
& Type of injury (closed/open): closed \\
& Gender M/F: $8 / 2$
\end{tabular}


Idris 2014 (Continued)

\section{GCS on admission: 7}

\section{No cooling}

Age: mean (95\% Cl): 45.5 (35.0 to 56.1 ) years

Type of injury (closed/open): closed

Gender M/F: 10/3

GCS on admission: 6

Inclusion criteria: $\geq 12$ years of age and above, severe head injury with GCS 6 to 7 , require decompressive craniectomy, able to be followed-up after 6 months being discharged from the hospital, and consented by next of kin or guardians

Exclusion criteria: penetrating brain injury, significant drop in blood pressure and/or significant hypoxia prior to admission, bilateral fixed and dilated pupils, severe injury to other organ systems which may lead to marked morbidity or even mortality, concomitant traumatic spinal cord injury, known premorbid immune or neurological diseases, severe head injury with only extradural haematoma, and known pre-morbid condition prior to the accident, including history of seizures

Country: Malaysia

Setting: hospital

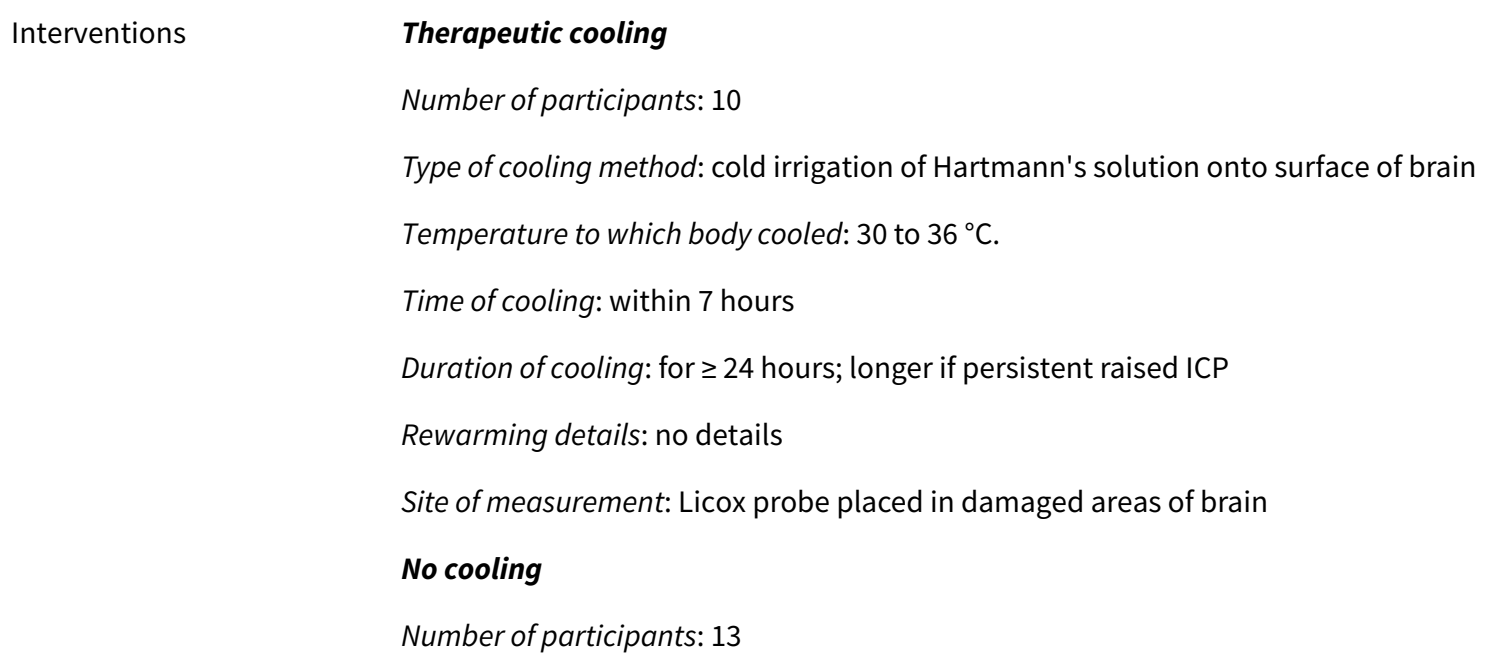

\section{Risk of bias}

\begin{tabular}{lll}
\hline Bias & Authors' judgement & Support for judgement \\
\hline $\begin{array}{l}\text { Random sequence genera- } \\
\text { tion (selection bias) }\end{array}$ & Unclear risk & Described as randomised but insufficient details \\
\hline
\end{tabular}


Idris 2014 (Continued)

$\begin{aligned} & \text { Allocation concealment } \\ & \text { (selection bias) }\end{aligned} \quad \begin{aligned} & \text { Unclear risk sealed envelopes which were blinded to the consenting individuals and } \\ & \text { clinicians, but insufficient details of how this blinding was ensured }\end{aligned}$

Blinding of participants Unclear risk Unclear if lack of blinding would influence performance for this outcome
and personnel (performance bias): GOS

\begin{tabular}{lll}
\hline $\begin{array}{l}\text { Blinding of participants } \\
\text { and personnel (perfor- } \\
\text { mance bias): pneumonia }\end{array}$ & Unclear risk & Unclear if lack of blinding would influence performance for this outcome \\
\hline $\begin{array}{l}\text { Blinding of outcome as- } \\
\text { sessment (detection bias): } \\
\text { mortality; pneumonia }\end{array}$ & Low risk & $\begin{array}{l}\text { No details; lack of outcome assessor blinding is unlikely to influence outcome } \\
\text { data }\end{array}$ \\
\hline $\begin{array}{l}\text { Blinding of outcome as- } \\
\text { sessment (detection bias): } \\
\text { GOS }\end{array}$ & Unclear risk & No details \\
\hline $\begin{array}{l}\text { Incomplete outcome data } \\
\text { (attrition bias) }\end{array}$ & Low risk & No apparent losses \\
$\begin{array}{l}\text { All outcomes } \\
\text { Selective reporting (re- } \\
\text { porting bias) }\end{array}$ & Unclear risk & $\begin{array}{l}\text { Clinical trials registration or pre-published protocol not reported. Insufficient } \\
\text { information to make judgement }\end{array}$ \\
\hline $\begin{array}{l}\text { Other bias } \\
\text { Unclear risk }\end{array}$ & $\begin{array}{l}\text { Participants in normothermia group were older. Unclear if this would affect re- } \\
\text { sults }\end{array}$ \\
\hline
\end{tabular}

Ishikura 1998

\begin{tabular}{ll} 
Methods & Randomised controlled trial, paralle \\
\hline Participants & Total number of participants: 11 \\
Baseline characteristics: & Therapeutic cooling \\
& Age: no details \\
& Gender M/F: no details \\
& Weight kg: no details \\
& GCS on admission: 3 to 8 \\
Type of injury (closed/open): closed \\
No cooling \\
Age: no details \\
Gender M/F: no details \\
Weight $k g:$ no details \\
GCS on admission: 3 to 8
\end{tabular}


Ishikura 1998 (Continued)

Type of injury (closed/open): closed

Inclusion criteria: severe closed head injuries, GCS 3 to 8

Exclusion criteria: no details

Country: Japan

Setting: hospital

Therapeutic cooling
Number of participants: 7
Method of cooling: no details
Target temperature: no details
Time of cooling: no details
Duration of cooling: no details
Rewarming details: no details
Site of measurement: no details
No cooling
Number of participants: 4
Outcomes measured in study: platelet count, thrombopoietin levels, mortality
Funding/declarations of interest: no details
Study dates:not reported
Note: abstract only with very limited detail. Mortality is reported in the hypothermia group; it is not
clear from the abstract whether there were no deaths in control group

\section{Risk of bias}

\begin{tabular}{lll}
\hline Bias & Authors' judgement & Support for judgement \\
\hline $\begin{array}{l}\text { Random sequence genera- } \\
\text { tion (selection bias) }\end{array}$ & High risk & $\begin{array}{l}\text { Described as random sampling but no additional details. Uneven number of } \\
\text { participants in each group }\end{array}$ \\
\hline $\begin{array}{l}\text { Allocation concealment } \\
\text { (selection bias) }\end{array}$ & Unclear risk & No details. Abstract only \\
\hline $\begin{array}{l}\text { Blinding of participants } \\
\text { and personnel (perfor- } \\
\text { mance bias): mortality }\end{array}$ & Low risk & Lack of blinding unlikely to influence performance for this outcome \\
\hline $\begin{array}{l}\text { Blinding of outcome as- } \\
\text { sessment (detection bias): } \\
\text { mortality; pneumonia }\end{array}$ & Low risk & Lack of blinding unlikely to influence outcome assessment for this outcome \\
\hline $\begin{array}{l}\text { Incomplete outcome data } \\
\text { (attrition bias) } \\
\begin{array}{l}\text { All outcomes } \\
\hline\end{array}\end{array}$ & High risk & Data not clearly reported on mortality for control group \\
\hline
\end{tabular}


Ishikura 1998 (Continued)

\begin{tabular}{|c|c|c|}
\hline $\begin{array}{l}\text { Selective reporting (re- } \\
\text { porting bias) }\end{array}$ & Unclear risk & $\begin{array}{l}\text { Clinical trials registration or pre-published protocol not reported. Insufficient } \\
\text { information to make judgement }\end{array}$ \\
\hline
\end{tabular}

Other bias Unclear risk No other sources identified but abstract with very limited detail

Jiang 2000

\begin{tabular}{|c|c|}
\hline Methods & Randomised controlled trial, parallel group \\
\hline \multirow[t]{16}{*}{ Participants } & Total number of participants: 87 \\
\hline & Baseline characteristics: \\
\hline & Therapeutic cooling \\
\hline & Age: mean 42.2 years \\
\hline & Gender M/F: 35/8 \\
\hline & GCS on admission: 5.04 \\
\hline & $\begin{array}{l}\text { Type of injury (closed/open): not stated but findings on CT scan of haematoma, contusion and traumatic } \\
\text { subarachnoid haemorrhage }\end{array}$ \\
\hline & No cooling \\
\hline & Age: mean 40.6 years \\
\hline & Gender M/F: $37 / 7$ \\
\hline & GCS on admission: 5.14 \\
\hline & Type of injury (closed/open): as above \\
\hline & Inclusion criteria: patients with severe traumatic brain injury, GCS $\leq 8$ \\
\hline & Exclusion criteria: no details \\
\hline & Country: China \\
\hline & Setting: hospital \\
\hline
\end{tabular}

\section{Therapeutic cooling}

Number of participants: 43

Method of cooling: cooling blankets beneath body

Target temperature: 33 to $35^{\circ} \mathrm{C}$

Time of cooling: immediately after admission

Duration of cooling: 3 to 14 days (until ICP returned to normal level $15 \mathrm{mmHg}$ )

Rewarming details: Once participant's ICP returned to normal levels, passively rewarmed to a temperature of 37 to $38.3^{\circ} \mathrm{C}$ at a rate $\leq 1{ }^{\circ} \mathrm{C} /$ hour, by gradual adjustment of the blanket thermostat

Site of temperature measurement: rectal

\section{No cooling}

Number of participants: 44 
Jiang 2000 (Continued)

Target temperature: 37 to $38^{\circ} \mathrm{C}$

Duration of temperature management: 14 days

Outcomes Outcomes measured in study: complications (including pneumonia at 1 year post injury), ICP, blood glu-
cose values, serum electrolyte levels, mortality at 1 year post injury, GOS at 1 year post injury

Notes $\quad$ Funding/declarations of interest: no details
Study dates: May 1992 to May 1998

\section{Risk of bias}

\begin{tabular}{|c|c|c|}
\hline Bias & Authors' judgement & Support for judgement \\
\hline $\begin{array}{l}\text { Random sequence genera- } \\
\text { tion (selection bias) }\end{array}$ & Unclear risk & Participants described as randomly assigned; no additional details \\
\hline $\begin{array}{l}\text { Allocation concealment } \\
\text { (selection bias) }\end{array}$ & Unclear risk & No details \\
\hline $\begin{array}{l}\text { Blinding of participants } \\
\text { and personnel (perfor- } \\
\text { mance bias): mortality }\end{array}$ & Low risk & Lack of blinding unlikely to influence performance for this outcome \\
\hline $\begin{array}{l}\text { Blinding of participants } \\
\text { and personnel (perfor- } \\
\text { mance bias): GOS }\end{array}$ & Unclear risk & Unclear if lack of blinding would influence performance for this outcome \\
\hline $\begin{array}{l}\text { Blinding of participants } \\
\text { and personnel (perfor- } \\
\text { mance bias): pneumonia }\end{array}$ & Unclear risk & Unclear if lack of blinding would influence performance for this outcome \\
\hline $\begin{array}{l}\text { Blinding of outcome as- } \\
\text { sessment (detection bias): } \\
\text { mortality; pneumonia }\end{array}$ & Low risk & $\begin{array}{l}\text { No details; lack of outcome assessor blinding is unlikely to influence outcome } \\
\text { data }\end{array}$ \\
\hline $\begin{array}{l}\text { Blinding of outcome as- } \\
\text { sessment (detection bias): } \\
\text { GOS }\end{array}$ & Low risk & $\begin{array}{l}\text { Neurological outcomes were assessed (GOS) by an expert unaware of treat- } \\
\text { ment assignment }\end{array}$ \\
\hline $\begin{array}{l}\text { Incomplete outcome data } \\
\text { (attrition bias) } \\
\text { All outcomes }\end{array}$ & Low risk & No apparent losses \\
\hline $\begin{array}{l}\text { Selective reporting (re- } \\
\text { porting bias) }\end{array}$ & Unclear risk & $\begin{array}{l}\text { Clinical trials registration or pre-published protocol not reported. Insufficient } \\
\text { information to make judgement }\end{array}$ \\
\hline Other bias & Low risk & No apparent other sources of bias \\
\hline
\end{tabular}

Lee 2010

\begin{tabular}{ll}
\hline Methods & Randomised controlled trial, parallel group \\
\hline Participants & Total number of participants: 31 \\
& Baseline characteristics \\
\hline
\end{tabular}


Lee 2010 (Continued)

\section{Therapeutic cooling}

Age: mean (SD) $44.0( \pm 15.1)$ years

Gender M/F: 9/6

GCS on admission: mean (SD) $6.3( \pm 1.2)$

Type of injury (closed/open): not reported

\section{No cooling}

Age: mean (SD) $43.5( \pm 16.4)$ years

Gender M/F: 10/6

GCS on admission: mean (SD) $6.4( \pm 1.3)$

Type of injury (closed/open): not reported

Inclusion criteria: a history of traumatic brain injury, GCS of 4 to 8 , and brain damage confirmed by sequential CT scanning within 6 hours after trauma

Exclusion criteria: pregnant women, patients $<12$ years or $>70$ years of age, a GCS score of 3, patients with multiple injuries, those with any previous disabling neurologic disease

Country: China

Setting: university hospital

Interventions

Therapeutic cooling

Number of participants: 15

Method of cooling: surface cooling, water-circulating blankets, ice pillows

Target temperature: 33 to $35^{\circ} \mathrm{C}$

Time of cooling: immediately after surgery for participants with evacuated mass lesions and after arrival in the ICU

Duration of cooling: assumed to be $\geq 24$ hours from information reported in the results section of the full report

Rewarming details: no details

Site of temperature measurement: brain

\section{No cooling}

Number of participants: 16

Outcomes

Outcomes measured in study: length of ICU stay, ICP, $\mathrm{P}_{\mathrm{ti}} \mathrm{O}_{2}, \mathrm{GOS}$ at 6 months, mortality at 6 months, and complications

Note: participants were post-craniotomy. Participants divided into three groups. However comparisons included in this review for just two groups. 'No cooling group' had ICP/CPP-guided management only and therapeutic cooling group had combined mild hypothermia and ICP/CPP-guided management

\section{Risk of bias}


Lee 2010 (Continued)

Bias Authors' judgement Support for judgement

\begin{tabular}{lll}
\hline $\begin{array}{l}\text { Random sequence genera- } \\
\text { tion (selection bias) }\end{array}$ & Unclear risk & $\begin{array}{l}\text { Described as a randomised controlled trial; no additional details on methods } \\
\text { of randomisation }\end{array}$ \\
\hline $\begin{array}{l}\text { Allocation concealment } \\
\text { (selection bias) }\end{array}$ & Unclear risk & No details
\end{tabular}

\begin{tabular}{|c|c|c|}
\hline $\begin{array}{l}\text { Blinding of participants } \\
\text { and personnel (perfor- } \\
\text { mance bias): mortality }\end{array}$ & Low risk & Lack of blinding unlikely to influence performance for this outcome \\
\hline $\begin{array}{l}\text { Blinding of participants } \\
\text { and personnel (perfor- } \\
\text { mance bias): GOS }\end{array}$ & Unclear risk & Unclear if lack of blinding would influence performance for this outcome \\
\hline $\begin{array}{l}\text { Blinding of outcome as- } \\
\text { sessment (detection bias): } \\
\text { mortality; pneumonia }\end{array}$ & Low risk & $\begin{array}{l}\text { No details; lack of outcome assessor blinding is unlikely to influence outcome } \\
\text { data }\end{array}$ \\
\hline $\begin{array}{l}\text { Blinding of outcome as- } \\
\text { sessment (detection bias): } \\
\text { GOS }\end{array}$ & Unclear risk & No details \\
\hline $\begin{array}{l}\text { Incomplete outcome data } \\
\text { (attrition bias) } \\
\text { All outcomes }\end{array}$ & Low risk & No apparent losses \\
\hline $\begin{array}{l}\text { Selective reporting (re- } \\
\text { porting bias) }\end{array}$ & Unclear risk & $\begin{array}{l}\text { Clinical trials registration or pre-published protocol not reported. Insufficient } \\
\text { information to make judgement }\end{array}$ \\
\hline Other bias & Low risk & No other sources of bias identified \\
\hline
\end{tabular}

Li 2008

\begin{tabular}{ll}
\hline Methods & Randomised controlled trial, parallel group \\
\hline Participants & Total number of participants: 43 \\
Baseline characteristics & Therapeutic cooling \\
& Age: mean (SD) 37.05 ( \pm 15.67$)$ years \\
& Type of injury (closed/open): closed \\
& Gender M/F: $13 / 7$ \\
& GCS on admission: GCS 3 to 5: 7/20; GCS 6 to 8: $13 / 20$ \\
& No cooling \\
& Age: mean (SD) 38.96 ( \pm 14.18$)$ years \\
& Type of injury (closed/open): closed \\
& Gender M/F: $17 / 6$
\end{tabular}


Li 2008 (Continued)

GCS on admission: GCS 3 to 5: 8/23; GCS 6 to 8: $15 / 23$

Inclusion criteria: isolated severe head injury, admission within 4 hours after head injury, GCS $\leq 8$, unequivocal contusion and laceration of the brain shown by CT scanning, 16 to 70 years of age, informed consent signed if enrolled in this study, and those who could accept hypothermia therapy immediately after admission

Exclusion criteria: combined injury, open craniocerebral injury, traumatic shock, pregnant or menstruating women, patients with hepatic diseases, blood diseases, or diseases affecting blood clotting, anticoagulation therapy, those transferred to other hospitals or withdrawn from this study, surgical operations, patients with severe complication receiving hypothermia therapy, patients who died within 72 hours or accepted component blood transfusion and drug treatment promoting coagulation or fibrinolysis

Country: China

Setting: neurosurgical ICU

\section{Therapeutic cooling}

Number of participants: 20

Method of cooling: ice blanket, ice cap and ice cubes

Target temperature: 32 to $35^{\circ} \mathrm{C}$

Time of cooling: immediately

Duration of cooling: no details

Rewarming details: no details

Site of measurement: no details

\section{No cooling}

Number of participants: 23

Target temperature: 37.0 to $38.0^{\circ} \mathrm{C}$

\begin{tabular}{lll}
\hline Outcomes & Outcomes measured in study: coagulation variables, GOS at 6 months \\
\hline Notes & $\begin{array}{l}\text { Funding/declarations of interest: grant from the Natural Science Fund of Hainan Province, China } \\
\text { Study dates: October 2006 to September } 2007\end{array}$ \\
\hline Risk of bias & Authors' judgement & Support for judgement \\
\hline Bias & Unclear risk & Described as randomised; no additional details \\
\hline $\begin{array}{l}\text { Random sequence genera- } \\
\text { tion (selection bias) }\end{array}$ & Unclear risk & No details \\
\hline $\begin{array}{l}\text { Allocation concealment } \\
\text { (selection bias) }\end{array}$ & Unclear risk & Unclear if lack of blinding would influence performance \\
\hline $\begin{array}{l}\text { Blinding of participants } \\
\text { and personnel (perfor- } \\
\text { mance bias): GOS }\end{array}$ & & \\
\hline
\end{tabular}


Li 2008 (Continued)

Blinding of outcome as- Unclear risk No details; unclear if lack of blinding would influence results sessment (detection bias): GOS

Incomplete outcome data Low risk No losses
(attrition bias)
All outcomes

\begin{tabular}{lll}
\hline $\begin{array}{l}\text { Selective reporting (re- } \\
\text { porting bias) }\end{array}$ & Unclear risk & $\begin{array}{l}\text { Clinical trials registration or pre-published protocol not reported. Insufficient } \\
\text { information to make judgement }\end{array}$ \\
\hline Other bias & Low risk & No other sources of bias identified \\
\hline
\end{tabular}

Li 2009

\begin{tabular}{|c|c|}
\hline Methods & Randomised controlled trial, parallel group \\
\hline \multirow[t]{14}{*}{ Participants } & Total number of participants: 22 \\
\hline & Baseline characteristics: \\
\hline & Therapeutic cooling \\
\hline & Age: 8 to 96 months \\
\hline & GCS on admission: 6.4 (SD 1.8) \\
\hline & Type of injury (closed/open): not stated \\
\hline & No cooling \\
\hline & Age: 6 to 108 months \\
\hline & GCS on admission: 6.5 (SD 1.7) \\
\hline & Type of injury (closed/open): not stated \\
\hline & Inclusion criteria: children of both genders ( 6 to 108 months of age) with GCS $\leq 8$ \\
\hline & $\begin{array}{l}\text { Exclusion criteria: Other serious accompanying injuries, history of neurological conditions and/or } \\
\text { chronic disease states }\end{array}$ \\
\hline & Country: China \\
\hline & Setting: children's hospital \\
\hline
\end{tabular}

Interventions

\section{Therapeutic cooling}

Number of participants: 12

Method of cooling: cooling cap

Target temperature: $34.5( \pm 0.2)^{\circ} \mathrm{C}$

Time of cooling: average time taken before initiation of treatment $7.2( \pm 1.4)$ hours after injury

Duration of cooling: 72 hours

Rewarming details: no details

Site of temperature measurement: intracranial 
Li 2009 (Continued)

\section{No cooling}

Number of participants: 10

Target temperature: intracranial temperatures were 37.5 to $38.5^{\circ} \mathrm{C}$

Outcomes

Outcomes measured in study: mortality, heart rate, blood pressure, $\mathrm{pH}$ and electrolyte levels, ICP, cerebrospinal fluid, biochemical markers

Notes Funding/declarations of interest: supported by grant, no conflicting financial interests declared

Study dates: January 2006 to August 2007

\section{Risk of bias}

\begin{tabular}{|c|c|c|}
\hline Bias & Authors' judgement & Support for judgement \\
\hline \multirow[t]{2}{*}{$\begin{array}{l}\text { Random sequence genera- } \\
\text { tion (selection bias) }\end{array}$} & High risk & $\begin{array}{l}\text { "The patients were divided randomly into a moderate hypothermia group (HY- } \\
\text { PO group; } n=12 \text { ) and a normothermia group (NORM group; } n=10 \text { ) on the ba- } \\
\text { sis of arrival date (odd number = HYPO; even number = NORM)" }\end{array}$ \\
\hline & & Unacceptable randomisation \\
\hline $\begin{array}{l}\text { Allocation concealment } \\
\text { (selection bias) }\end{array}$ & Unclear risk & $\begin{array}{l}\text { It is unclear whether study investigators revealed randomisation code (odd/ } \\
\text { even arrival date) to personnel and whether this method of randomisation was } \\
\text { conducted externally }\end{array}$ \\
\hline $\begin{array}{l}\text { Blinding of participants } \\
\text { and personnel (perfor- } \\
\text { mance bias): mortality }\end{array}$ & Low risk & Lack of blinding unlikely to influence performance for this outcome \\
\hline $\begin{array}{l}\text { Blinding of outcome as- } \\
\text { sessment (detection bias): } \\
\text { mortality; pneumonia }\end{array}$ & Low risk & $\begin{array}{l}\text { No details; lack of outcome assessor blinding is unlikely to influence outcome } \\
\text { data }\end{array}$ \\
\hline $\begin{array}{l}\text { Incomplete outcome data } \\
\text { (attrition bias) } \\
\text { All outcomes }\end{array}$ & Low risk & No apparent losses \\
\hline $\begin{array}{l}\text { Selective reporting (re- } \\
\text { porting bias) }\end{array}$ & Unclear risk & $\begin{array}{l}\text { Clinical trials registration or pre-published protocol not reported. Insufficient } \\
\text { information to make judgement }\end{array}$ \\
\hline Other bias & Low risk & No other sources of bias identified \\
\hline
\end{tabular}

Marion 1997

\begin{tabular}{ll}
\hline Methods & Randomised controlled trial, parallel group \\
\hline Participants & Total number of participants: 82 \\
& Baseline characteristics: \\
& Therapeutic cooling \\
& Age: mean (SD) $31( \pm 12)$ years \\
& Gender M/F: $36 / 4$ \\
GCS on admission: not reported as mean, balanced between groups
\end{tabular}


Marion 1997 (Continued)

Type of injury (closed/open): closed

\section{No cooling}

Age: mean $(S D) 35( \pm 15)$ years

Gender M/F: 33/9

GCS on admission: not reported as mean, balanced between groups

Type of injury (closed/open): closed

Inclusion criteria: closed head injury, GCS 3 to 7,16 to 75 years of age, admission within 6 hours after the injury, and an inability to follow commands

Exclusion criteria: clinical brain death, prolonged hypoxia or hypotension, gunshot wound, pregnancy, undetermined time of injury, or normal findings on a CT scan of the head

Country: USA

Setting: hospital

\section{Therapeutic cooling}

Number of participants: 40

Method of cooling: cooling blankets placed above and below the participant and nasogastric lavage with iced saline

Target temperature: 32 to $33^{\circ} \mathrm{C}$

Time of cooling: within 6 hours

Duration of cooling: 24 hours

Rewarming details: over 12 hours, participants were passively rewarmed to a temperature of 37 to $38.5^{\circ} \mathrm{C}$, at a rate $\geq 1^{\circ} \mathrm{C}$ per hour, by a gradual adjustment of the blanket thermostat.

Site of temperature measurement: brain, rectal

\section{No cooling}

Number of participants: 42

Method of temperature management: participants in the normothermia group who had rectal temperatures $<37^{\circ} \mathrm{C}$ at admission were passively rewarmed over a period of 12 hours. No further details

Target temperature 37 to $38.5^{\circ} \mathrm{C}$

Duration of cooling: maintained for 5 days of study period tality during stay in trauma centre

Study dates: February 1991 to September 1994

\section{Risk of bias}

\begin{tabular}{lll}
\hline Bias & Authors' judgement & Support for judgement \\
\hline $\begin{array}{l}\text { Random sequence genera- } \\
\text { tion (selection bias) }\end{array}$ & Low risk & "Using a block-randomization scheme"
\end{tabular}


Marion 1997 (Continued)

$\begin{aligned} & \text { Allocation concealment } \\ & \text { (selection bias) }\end{aligned}$
Unclear risk Use of sealed envelopes but no additional details

\begin{tabular}{ll}
\hline Blinding of participants $\quad$ Low risk $\quad$ Lack of blinding unlikely to influence performance for this outcome \\
and personnel (perfor-
\end{tabular}

\begin{tabular}{|c|c|c|}
\hline $\begin{array}{l}\text { Blinding of participants } \\
\text { and personnel (perfor- } \\
\text { mance bias): GOS }\end{array}$ & Unclear risk & Unclear if lack of blinding would influence performance for this outcome \\
\hline $\begin{array}{l}\text { Blinding of outcome as- } \\
\text { sessment (detection bias): } \\
\text { mortality; pneumonia }\end{array}$ & Low risk & $\begin{array}{l}\text { No details; lack of outcome assessor blinding is unlikely to influence outcome } \\
\text { data }\end{array}$ \\
\hline $\begin{array}{l}\text { Blinding of outcome as- } \\
\text { sessment (detection bias): } \\
\text { GOS }\end{array}$ & Low risk & $\begin{array}{l}\text { "A specialist in physical medicine and rehabilitation who was unaware of the } \\
\text { patients' treatment assignments determined the neurologic outcome 3, 6, and } \\
12 \text { months after the injury" }\end{array}$ \\
\hline $\begin{array}{l}\text { Incomplete outcome data } \\
\text { (attrition bias) } \\
\text { All outcomes }\end{array}$ & Low risk & No apparent losses \\
\hline $\begin{array}{l}\text { Selective reporting (re- } \\
\text { porting bias) }\end{array}$ & Unclear risk & $\begin{array}{l}\text { Clinical trials registration or pre-published protocol not reported. Insufficient } \\
\text { information to make judgement }\end{array}$ \\
\hline Other bias & Low risk & No other sources of bias identified \\
\hline
\end{tabular}

Meissner 2003a

\begin{tabular}{|c|c|}
\hline Methods & Randomised controlled trial, parallel design \\
\hline Participants & Patients with severe blunt head injury. Intervention was started within 8 hours of injury \\
\hline \multirow[t]{9}{*}{ Interventions } & Total number of participants: 16 \\
\hline & Therapeutic cooling \\
\hline & Number of participants: 7 \\
\hline & Temperature to which body cooled: 32 to $33^{\circ} \mathrm{C}$ \\
\hline & $\begin{array}{l}\text { Time of cooling (immediately on admission; deferred until intracranial pressure is uncontrollable): within } \\
8 \text { hours }\end{array}$ \\
\hline & Duration of cooling: 48 hours \\
\hline & No cooling \\
\hline & Number of participants: 9 \\
\hline & Target temperature: 36 to $37^{\circ} \mathrm{C}$ \\
\hline Outcomes & Outcomes measured in study: heart rate, mean blood pressure, plasma cortisol \\
\hline \multirow[t]{2}{*}{ Notes } & Funding/declarations of interest: not reported \\
\hline & Study dates: not reported \\
\hline
\end{tabular}


Meissner 2003a (Continued)

Note: abstract only

\section{Risk of bias}

Bias Authors' judgement Support for judgement

Random sequence genera- Unclear risk Described as randomised; no additional details. Abstract only. tion (selection bias)

Allocation concealment $\quad$ Unclear risk $\quad$ Not described
(selection bias)

Incomplete outcome data Low risk Abstract only, losses not reported.
(attrition bias)

(attrition bias)

All outcomes

\begin{tabular}{|c|c|c|}
\hline $\begin{array}{l}\text { Selective reporting (re- } \\
\text { porting bias) }\end{array}$ & Unclear risk & $\begin{array}{l}\text { Clinical trials registration or pre-published protocol not reported. Insufficient } \\
\text { information to make judgement }\end{array}$ \\
\hline
\end{tabular}

\begin{tabular}{ll}
\hline Other bias $\quad$ Unclear risk $\quad$ No other sources of bias identified. Limited detail in published abstract \\
\hline
\end{tabular}

Meissner 2003b

Methods Randomised controlled trial, parallel group

Participants

Total number of participants: 24

\section{Baseline characteristics:}

Therapeutic cooling

Age: median 30 years

Gender M/F: 9/2

GCS on admission: median 6

Type of injury (closed/open): closed

\section{No cooling}

Age: median 48 years

Gender M/F: 12/1

GCS on admission: median 5

Type of injury (closed/open): closed

Note: participants in hypothermia group were significantly younger than participants in control group

Inclusion criteria: participants with severe head injuries $(\mathrm{GCS} \leq 9)$ who reached the hospital early enough to induce hypothermia, at $\leq 8$ hours after trauma

Exclusion criteria: patients $<18$ years of age, $\mathrm{SBP}<90 \mathrm{mmHg}$, an arterial oxygen saturation $<90$ $\mathrm{mmHg}$ for $>30$ minutes during resuscitation, penetrating head wound

Country: Germany

Setting: hospital 
Meissner 2003b (Continued) Interventions

\section{Therapeutic cooling}

Number of participants: 11

Method of cooling: external convection and conduction via water blankets and forced air

Target temperature: 32 to $33^{\circ} \mathrm{C}$

Time of cooling: "As early as possible"

Duration of cooling: 24 to 48 hours

Rewarming details: rewarming was achieved by isolation and, if necessary, active warming

Site of temperature measurement: rectal, bladder

\section{No cooling}

Number of participants: 13

Method of temperature management: temperature was maintained by warming or, in cases of pyrexia, by administration of antipyretics (i.e. metamizol) and/or local cooling with cold compresses

Target temperature: 36 to $37^{\circ} \mathrm{C}$

\begin{tabular}{ll}
\hline Outcomes & Outcomes measured in study: mortality, serum concentrations \\
\hline Notes & $\begin{array}{l}\text { Funding/declarations of interest: no details } \\
\text { Study dates: not reported }\end{array}$ \\
\hline
\end{tabular}

\section{Risk of bias}

\begin{tabular}{|c|c|c|}
\hline Bias & Authors' judgement & Support for judgement \\
\hline $\begin{array}{l}\text { Random sequence genera- } \\
\text { tion (selection bias) }\end{array}$ & Unclear risk & Described as randomised but no details \\
\hline $\begin{array}{l}\text { Allocation concealment } \\
\text { (selection bias) }\end{array}$ & Unclear risk & No details \\
\hline $\begin{array}{l}\text { Blinding of participants } \\
\text { and personnel (perfor- } \\
\text { mance bias): mortality }\end{array}$ & Low risk & Lack of blinding unlikely to influence performance for this outcome \\
\hline $\begin{array}{l}\text { Blinding of outcome as- } \\
\text { sessment (detection bias): } \\
\text { mortality; pneumonia }\end{array}$ & Low risk & $\begin{array}{l}\text { No details; lack of outcome assessor blinding is unlikely to influence outcome } \\
\text { data }\end{array}$ \\
\hline $\begin{array}{l}\text { Incomplete outcome data } \\
\text { (attrition bias) } \\
\text { All outcomes }\end{array}$ & Low risk & $\begin{array}{l}\text { Outcomes were not reported for } 4 \text { randomised participants - reasons were ex- } \\
\text { plained and unlikely to relate to true outcome }\end{array}$ \\
\hline $\begin{array}{l}\text { Selective reporting (re- } \\
\text { porting bias) }\end{array}$ & Unclear risk & $\begin{array}{l}\text { Clinical trials registration or pre-published protocol not reported. Insufficient } \\
\text { information to make judgement }\end{array}$ \\
\hline Other bias & Low risk & No other sources of bias identified \\
\hline
\end{tabular}


Qiu 2005

\begin{tabular}{|c|c|}
\hline Methods & Randomized controlled trial, parallel group \\
\hline Participants & $\begin{array}{l}\text { Total number of participants: } 86 \\
\text { Baseline characteristics: } \\
\text { Therapeutic cooling } \\
\text { Age: mean } 40.0 \text { years } \\
\text { Type of injury (closed/open): not reported } \\
\text { Gender M/F: } 26 / 17 \\
\text { GCS on admission: apparent typo in study report, therefore not reported in review } \\
\text { No cooling } \\
\text { Age: mean } 42.3 \text { years } \\
\text { Type of injury (closed/open): not reported } \\
\text { Gender M/F: } 30 / 13 \\
\text { GCS on admission: GCS } 3 \text { to } 5: 26 / 43 ; G C S>6: 17 / 43 \\
\text { Inclusion criteria: history of traumatic brain injury, GCS }<8 \text {, brain injury having been diagnosed by CT } \\
\text { within } 24 \text { hours } \\
\text { Exclusion criteria: pregnant women, }<14 \text { years and }>65 \text { years of age, those with haemorrhagic shock } \\
\text { or haematologic diseases such as leukaemia and other serious organic diseases } \\
\text { Country: China } \\
\text { Setting: hospital }\end{array}$ \\
\hline Interventions & $\begin{array}{l}\text { Therapeutic cooling } \\
\text { Number of participants: } 43 \\
\text { Method of cooling: water-circulating cooling blanket and cooling cap. If required refrigerated ice bags } \\
\text { were placed around the groin and neck } \\
\text { Target temperature: } 33.0 \text { to } 35.0^{\circ} \mathrm{C} \\
\text { Time of cooling: immediately after admission or } 3 \text { to } 5 \text { days post-craniotomy } \\
\text { Duration of cooling: } 3 \text { to } 5 \text { days } \\
\text { Rewarming details: no details } \\
\text { Site of measurement: nasopharyngeal, rectal, brain } \\
\text { No cooling } \\
\text { Number of participants: } 43 \\
\text { Target temperature: } 38{ }^{\circ} \mathrm{C}\end{array}$ \\
\hline Outcomes & Outcomes measured in study: haemodynamic and respiratory variables, complications, GOS at 2 years \\
\hline Notes & $\begin{array}{l}\text { Funding/declarations of interest: not reported } \\
\text { Study dates: } 1998 \text { to } 2001\end{array}$ \\
\hline
\end{tabular}


Qiu 2005 (Continued)

\section{Risk of bias}

\begin{tabular}{|c|c|c|}
\hline Bias & Authors' judgement & Support for judgement \\
\hline $\begin{array}{l}\text { Random sequence genera- } \\
\text { tion (selection bias) }\end{array}$ & Unclear risk & Randomly assigned to groups; no additional details \\
\hline $\begin{array}{l}\text { Allocation concealment } \\
\text { (selection bias) }\end{array}$ & Unclear risk & No details \\
\hline $\begin{array}{l}\text { Blinding of participants } \\
\text { and personnel (perfor- } \\
\text { mance bias): mortality }\end{array}$ & Low risk & No details; lack of blinding unlikely to influence performance for this outcome \\
\hline $\begin{array}{l}\text { Blinding of participants } \\
\text { and personnel (perfor- } \\
\text { mance bias): GOS }\end{array}$ & Unclear risk & No details; unclear if lack of blinding would influence performance \\
\hline $\begin{array}{l}\text { Blinding of outcome as- } \\
\text { sessment (detection bias): } \\
\text { mortality; pneumonia }\end{array}$ & Low risk & Lack of blinding unlikely to influence outcome assessment \\
\hline $\begin{array}{l}\text { Blinding of outcome as- } \\
\text { sessment (detection bias): } \\
\text { GOS }\end{array}$ & Unclear risk & $\begin{array}{l}\text { No details; unclear if lack of blinding would influence assessment of outcome } \\
\text { data }\end{array}$ \\
\hline $\begin{array}{l}\text { Incomplete outcome data } \\
\text { (attrition bias) } \\
\text { All outcomes }\end{array}$ & Low risk & No losses \\
\hline $\begin{array}{l}\text { Selective reporting (re- } \\
\text { porting bias) }\end{array}$ & Unclear risk & $\begin{array}{l}\text { Clinical trials registration or pre-published protocol not reported. Insufficient } \\
\text { information to make judgement }\end{array}$ \\
\hline Other bias & Low risk & No other source of bias identified \\
\hline
\end{tabular}

Qiu 2007

Methods Randomized controlled trial, parallel group

\section{Participants}

Total number of participants: 80

\section{Baseline characteristics:}

\section{Therapeutic cooling}

Age: mean 41.3 years

Gender M/F: 25/15

GCS on admission: number of participants $<6$ on GCS $=24$

Type of injury (closed/open): closed (non-penetrating). All participants had craniotomies

\section{No cooling}

Age: mean 40.2 years

Gender M/F: 27/13 
Qiu 2007 (Continued)

GCS on admission: number of participants $<6$ on GCS $=23$

Type of injury (closed/open): closed (non-penetrating). All participants had craniotomies

Inclusion criteria: history of traumatic brain injury, GCS scores $\leq 8$, brain injury confirmed by sequential CT scanning within 6 hours after trauma

Exclusion criteria: pregnant women, patients $<19$ or $>65$ years of age, patients with multiple injuries, haemorrhagic shock, or without any brain stem reflex on initial examination, previous disabling neurologic disease

Country: China

Setting: neurological ICU in brain centre

\section{Therapeutic cooling}

Number of participants: 40

Method of cooling method: water-circulating cooling blanket, cooling cap. For those who failed to achieve target temperature successfully within 2 hours, refrigerated ice bags were placed around the groin and neck

Target temperature: brain temperature was maintained between 33 to $35^{\circ} \mathrm{C}$, and the rectal temperature between 34.5 to $36^{\circ} \mathrm{C}$

Time of cooling: directly after craniotomy

Duration of cooling: over 4 days

Rewarming details: spontaneously return to baseline during a period of 10 to 24 hours

Site of measurement: brain and rectal

\section{No cooling}

Number of participants: 40

Method of temperature management: routine pharmacologic or physical measures were applied to maintain body temperature $\leq 37.5^{\circ} \mathrm{C}$

Target temperature: brain temperature of 36.5 to $37.5^{\circ} \mathrm{C}$, rectal temperature of 37.5 to $38^{\circ} \mathrm{C}$.

Outcomes Outcomes measured in study: ICP, serum superoxide dismutase level, favourable neurologic outcome 1
year after injury, mortality at 1 year post injury

Notes Funding/declarations of interest: grant from Health Bureau of Hangzhou, Zheijang Province

Study dates: January 2002 to December 2003

\section{Risk of bias}

\begin{tabular}{lll}
\hline Bias & Authors' judgement & Support for judgement \\
\hline $\begin{array}{l}\text { Random sequence genera- } \\
\text { tion (selection bias) }\end{array}$ & Low risk & $\begin{array}{l}\text { "Patient was assigned to one of the following } 2 \text { groups in the neurologic inten- } \\
\text { sive care unit of our brain center by using a randomisation table" }\end{array}$ \\
\hline $\begin{array}{l}\text { Allocation concealment } \\
\text { (selection bias) }\end{array}$ & Low risk & $\begin{array}{l}\text { "Allocation and randomisation was concealed so that the study investigators } \\
\text { were not aware to which group the patient would be assigned, and the alloca- } \\
\text { tion sequence was protected until assignment." }\end{array}$ \\
& $\begin{array}{l}\text { No details on methods of concealment; sufficient information to suggest that } \\
\text { an adequate method was used. }\end{array}$ \\
\hline
\end{tabular}


Qiu 2007 (Continued)

Blinding of participants Low risk Lack of blinding unlikely to influence performance for this outcome and personnel (performance bias): mortality

Blinding of participants Unclear risk Unclear if lack of blinding would influence performance for this outcome
and personnel (perfor-
mance bias): GOS

\begin{tabular}{lll}
\hline $\begin{array}{l}\text { Blinding of outcome as- } \\
\text { sessment (detection bias): } \\
\text { mortality; pneumonia }\end{array}$ & Low risk & $\begin{array}{l}\text { No details; lack of outcome assessor blinding is unlikely to influence outcome } \\
\text { data }\end{array}$ \\
\hline $\begin{array}{l}\text { Blinding of outcome as- } \\
\text { sessment (detection bias): } \\
\text { GOS }\end{array}$ & Unclear risk & No details \\
\hline $\begin{array}{l}\text { Incomplete outcome data } \\
\begin{array}{l}\text { (attrition bias) } \\
\text { All outcomes }\end{array}\end{array}$ & Low risk & No apparent losses \\
\hline $\begin{array}{l}\text { Selective reporting (re- } \\
\text { porting bias) }\end{array}$ & Unclear risk & $\begin{array}{l}\text { Clinical trials registration or pre-published protocol not reported. Insufficient } \\
\text { information to make judgement }\end{array}$ \\
\hline \begin{tabular}{l} 
Other bias \\
\hline
\end{tabular} & Low risk & No other sources of bias identified \\
\hline
\end{tabular}

Shiozaki 1993

Methods $\quad$ Randomised controlled trial, parallel group

\section{Participants}

\section{Total number of participants: 33}

\section{Baseline characteristics:}

\section{Therapeutic cooling}

Age: mean (SD) $35.3( \pm 15.3)$ years

Gender M/F: 6/10

Type of injury (closed/open): not stated

\section{No cooling}

Age: mean (SD) 35.4 ( \pm 12.6$)$ years

Gender M/F: 10/7

Type of injury (closed/open): not stated

Inclusion criteria: participants in whom ICP remained $>20 \mathrm{mmHg}$ at 5 to 6 hours after induction of high-dose barbiturate therapy, GCS on admission $\leq 8$

Exclusion criteria: < 10 years, ICP controlled with high-dose barbiturate therapy alone, ICP equal to MAP before start of study

Country: Japan

Setting: Department of Traumatology at Osaka University Hospital 
Shiozaki 1993 (Continued) Interventions

\section{Therapeutic cooling}

Number of participants: 16

Method of cooling: surface cooling with water-circulating blankets above and below the participant

Target temperature: 33.5 to $34.5^{\circ} \mathrm{C}$

Time of cooling: no details

Duration of cooling: 2 days or until it was considered not to be effective

Rewarming details: slowly, core temperature was maintained between 35.5 to $36.5^{\circ} \mathrm{C}$ for 24 hours. If ICP increased $>20 \mathrm{mmHg}$ during rewarming, participant was recooled to $34^{\circ} \mathrm{C}$. If ICP remained $<20$ $\mathrm{mmHg}$ for $\geq 24$ hours, participants were rewarmed spontaneously to $>37^{\circ} \mathrm{C}$ with continuous infusion of barbiturates at $2 \mathrm{mg} / \mathrm{kg}$ to prevent shivering

Site of temperature measurement: bladder

\section{No cooling}

Number of participants: 17

Outcomes Outcomes measured in study: CPP, ICP, cerebral blood flow and $\mathrm{AVDO}_{2}$, complications (to include pneumonia), mortality at 6 months, GOS at 6 months

Notes

Funding/declarations of interest: no details

Study dates: May 1987 to April 1992

\section{Risk of bias}

\begin{tabular}{|c|c|c|}
\hline Bias & Authors' judgement & Support for judgement \\
\hline $\begin{array}{l}\text { Random sequence genera- } \\
\text { tion (selection bias) }\end{array}$ & Unclear risk & Participants randomly divided into two groups; no additional details \\
\hline $\begin{array}{l}\text { Allocation concealment } \\
\text { (selection bias) }\end{array}$ & Unclear risk & No details \\
\hline $\begin{array}{l}\text { Blinding of participants } \\
\text { and personnel (perfor- } \\
\text { mance bias): mortality }\end{array}$ & Low risk & Lack of blinding unlikely to influence performance for this outcome \\
\hline $\begin{array}{l}\text { Blinding of participants } \\
\text { and personnel (perfor- } \\
\text { mance bias): GOS }\end{array}$ & Unclear risk & Unclear if lack of blinding would influence performance for this outcome \\
\hline $\begin{array}{l}\text { Blinding of participants } \\
\text { and personnel (perfor- } \\
\text { mance bias): pneumonia }\end{array}$ & Unclear risk & Unclear if lack of blinding would influence performance for this outcome \\
\hline $\begin{array}{l}\text { Blinding of outcome as- } \\
\text { sessment (detection bias): } \\
\text { mortality; pneumonia }\end{array}$ & Low risk & $\begin{array}{l}\text { No details; lack of outcome assessor blinding is unlikely to influence outcome } \\
\text { data }\end{array}$ \\
\hline $\begin{array}{l}\text { Blinding of outcome as- } \\
\text { sessment (detection bias): } \\
\text { GOS }\end{array}$ & Unclear risk & No details \\
\hline
\end{tabular}


Shiozaki 1993 (Continued)

Incomplete outcome data Low risk Data reported for pneumonia has losses due to death within 48 hours. Howev(attrition bias)

All outcomes

\begin{tabular}{|c|c|c|}
\hline $\begin{array}{l}\text { Selective reporting (re- } \\
\text { porting bias) }\end{array}$ & Unclear risk & $\begin{array}{l}\text { Clinical trials registration or pre-published protocol not reported. Insufficient } \\
\text { information to make judgement }\end{array}$ \\
\hline
\end{tabular}

Other bias Low risk No other sources of bias identified

Shiozaki 1999

Methods Randomised controlled trial, parallel group

Participants

Total number of participants: 16

\section{Baseline characteristics:}

Therapeutic cooling

Age: mean (SD) $31.4( \pm 12.7)$ years

Gender M/F: 8/0

GCS on admission: mean (SD) $5.6( \pm 1.8)$

Type of injury (closed/open): not reported

No cooling

Age: mean (SD) 40.3 ( \pm 23.1 ) years

Gender M/F: 5/3

GCS on admission: mean (SD) $5.4( \pm 2.0)$

Type of injury (closed/open): not reported

Inclusion criteria: participants with severe head injury who required continuous infusion of barbiturate medication to control ICP, GCS $\leq 8$

Exclusion criteria: $<10$ years of age, ICP equal to MAP before start of study these patients, severe lifethreatening injury to other organs, unable to keep ICP $<20 \mathrm{mmHg}$ by using conventional therapies such as fluid restriction, hyperventilation, and high-dose barbiturate medications

Country: Japan

Setting: Department of Traumatology of Osaka University Hospital

\section{Therapeutic cooling}

Number of participants: 8

Method of cooling: water-circulating blankets above and below the participant

Target temperature: 33.5 to $34.5^{\circ} \mathrm{C}$

Time of cooling: after randomisation

Duration of cooling: 48 hours

Rewarming details: rewarmed slowly, approximately $1{ }^{\circ} \mathrm{C} /$ day, by using continuous infusion of barbiturates at $2 \mathrm{mg} / \mathrm{kg} / \mathrm{hour}$ to prevent shivering 
Site of temperature measurement: intracranial, lateral ventricle

\section{No cooling}

Number of participants: 8

Method of temperature management: surface cooling

Temperature maintenance details: barbiturates were continuously infused at 6 to $8 \mathrm{mg} / \mathrm{kg} / \mathrm{hour}$ during the initial 48 hours, followed by continuous infusion of barbiturates at $2 \mathrm{mg} / \mathrm{kg} /$ hour to prevent shivering

Target temperature: 36.5 to $37.5^{\circ} \mathrm{C}$

Duration of cooling: 5 days

\section{Outcomes}

Outcomes measured in study: pneumonia, meningitis, diabetes insipidus, GOS at 6 months (to include mortality), daily changes in CSF, concentrations of excitatory amino acids, concentrations of cytokines

Notes $\begin{aligned} & \text { Funding/declarations of interest: supported by a grant from the Ministry of Health and Welfare, Japan } \\ & \text { Study dates: } 1996 \text { to } 1998\end{aligned}$

\section{Risk of bias}

\begin{tabular}{|c|c|c|}
\hline Bias & Authors' judgement & Support for judgement \\
\hline $\begin{array}{l}\text { Random sequence genera- } \\
\text { tion (selection bias) }\end{array}$ & Unclear risk & Described as randomised; no additional details \\
\hline $\begin{array}{l}\text { Allocation concealment } \\
\text { (selection bias) }\end{array}$ & Unclear risk & No details \\
\hline $\begin{array}{l}\text { Blinding of participants } \\
\text { and personnel (perfor- } \\
\text { mance bias): mortality }\end{array}$ & Low risk & Lack of blinding unlikely to influence performance for this outcome \\
\hline $\begin{array}{l}\text { Blinding of participants } \\
\text { and personnel (perfor- } \\
\text { mance bias): GOS }\end{array}$ & Unclear risk & Unclear if lack of blinding would influence performance for this outcome \\
\hline $\begin{array}{l}\text { Blinding of participants } \\
\text { and personnel (perfor- } \\
\text { mance bias): pneumonia }\end{array}$ & Unclear risk & Unclear if lack of blinding would influence performance for this outcome \\
\hline $\begin{array}{l}\text { Blinding of outcome as- } \\
\text { sessment (detection bias): } \\
\text { mortality; pneumonia }\end{array}$ & Low risk & $\begin{array}{l}\text { No details; lack of outcome assessor blinding is unlikely to influence outcome } \\
\text { data }\end{array}$ \\
\hline $\begin{array}{l}\text { Blinding of outcome as- } \\
\text { sessment (detection bias): } \\
\text { GOS }\end{array}$ & Unclear risk & No details \\
\hline $\begin{array}{l}\text { Incomplete outcome data } \\
\text { (attrition bias) } \\
\text { All outcomes }\end{array}$ & Low risk & No loss of data observed \\
\hline $\begin{array}{l}\text { Selective reporting (re- } \\
\text { porting bias) }\end{array}$ & Unclear risk & $\begin{array}{l}\text { Clinical trials registration or pre-published protocol not reported. Insufficient } \\
\text { information to make judgement }\end{array}$ \\
\hline
\end{tabular}


Shiozaki 1999 (Continued)
Other bias
Low risk
No other sources of bias identified

Shiozaki 2001

Methods Randomised controlled trial, parallel group

Participants

Total number of participants: 91

Baseline characteristics:

Therapeutic cooling

Age: mean (SD) $35( \pm 20)$ years

Gender M/F: 35/10

GCS on admission: mean (SD) $5.5( \pm 1.7)$

Type of injury (closed/open): not reported

No cooling

Age: mean (SD) $42( \pm 17)$ years

Gender M/F: 31/15

GCS on admission: mean (SD) $5.1( \pm 1.9)$

Type of injury (closed/open): not reported

Inclusion criteria: GCS $\leq 8$ on admission, no severe life-threatening injury to another organ, ICP was maintained $<25 \mathrm{mmHg}$ by conventional therapies

Exclusion criteria: 84 participants were excluded for one of the following reasons: unable to maintain their ICP $<25 \mathrm{mmHg}$ despite conventional therapies (73 patients), ICP was not measured (9 patients), or informed consent was not obtained ( 2 patients)

Country: Japan

Setting: 11 medical centres in Japan

\section{Therapeutic cooling}

Number of participants: 45

Method of cooling: cooling blankets above and below the participant, nasogastric lavage with iced saline

Target temperature to which body cooled: 33.5 to $34.5^{\circ} \mathrm{C}$

Time of cooling: $<24$ hours after randomisation

Duration of cooling: 48 hours

Rewarming details: slowly, approximately $1^{\circ} \mathrm{C} /$ day, to a temperature of $37^{\circ} \mathrm{C}$ after 3 days

Site of temperature measurement: at discretion of the investigator, although brain temperature was recommended

\section{No cooling}

Number of participants: 46 
Shiozaki 2001 (Continued)

$$
\begin{aligned}
& \text { Method of temperature management: surface cooling } \\
& \text { Target temperature: } 36.5 \text { to } 37.5^{\circ} \mathrm{C} \\
& \text { Duration of temperature management: } 5 \text { days }
\end{aligned}
$$

Outcomes Outcomes measured in study: therapy intensity for control of ICP and CPP, GOS at 3 months (to include
mortality), pneumonia. Mortality also reported during hospital stay

Notes $\quad$ Funding/declarations of interest: grant from the Ministry of Health and Welfare, Japan

Study dates: February 1998 to January 2000

Note: some participant losses due to increase in ICP. We included the total number of participants in

\begin{tabular}{|c|c|c|}
\hline Bias & Authors' judgement & Support for judgement \\
\hline $\begin{array}{l}\text { Random sequence genera- } \\
\text { tion (selection bias) }\end{array}$ & Unclear risk & Described as randomised; no additional details \\
\hline $\begin{array}{l}\text { Allocation concealment } \\
\text { (selection bias) }\end{array}$ & Unclear risk & No details \\
\hline $\begin{array}{l}\text { Blinding of participants } \\
\text { and personnel (perfor- } \\
\text { mance bias): mortality }\end{array}$ & Low risk & Lack of blinding unlikely to influence performance for this outcome \\
\hline $\begin{array}{l}\text { Blinding of participants } \\
\text { and personnel (perfor- } \\
\text { mance bias): GOS }\end{array}$ & Unclear risk & Unclear if lack of blinding would influence performance for this outcome \\
\hline $\begin{array}{l}\text { Blinding of participants } \\
\text { and personnel (perfor- } \\
\text { mance bias): pneumonia }\end{array}$ & Unclear risk & Unclear if lack of blinding would influence performance for this outcome \\
\hline $\begin{array}{l}\text { Blinding of outcome as- } \\
\text { sessment (detection bias): } \\
\text { mortality; pneumonia }\end{array}$ & Low risk & $\begin{array}{l}\text { No details; lack of outcome assessor blinding is unlikely to influence outcome } \\
\text { data }\end{array}$ \\
\hline $\begin{array}{l}\text { Blinding of outcome as- } \\
\text { sessment (detection bias): } \\
\text { GOS }\end{array}$ & Unclear risk & No details \\
\hline $\begin{array}{l}\text { Incomplete outcome data } \\
\text { (attrition bias) } \\
\text { All outcomes }\end{array}$ & Low risk & $\begin{array}{l}\text { Some inevitable losses to data due to early mortality. Low number, clearly ex- } \\
\text { plained }\end{array}$ \\
\hline $\begin{array}{l}\text { Selective reporting (re- } \\
\text { porting bias) }\end{array}$ & Unclear risk & $\begin{array}{l}\text { Clinical trials registration or pre-published protocol not reported. Insufficient } \\
\text { information to make judgement }\end{array}$ \\
\hline Other bias & Unclear risk & Temperature measurement at discretion of physicians \\
\hline
\end{tabular}
the review outcome data as some losses were due to death

\section{Risk of bias}


Smrcka 2005

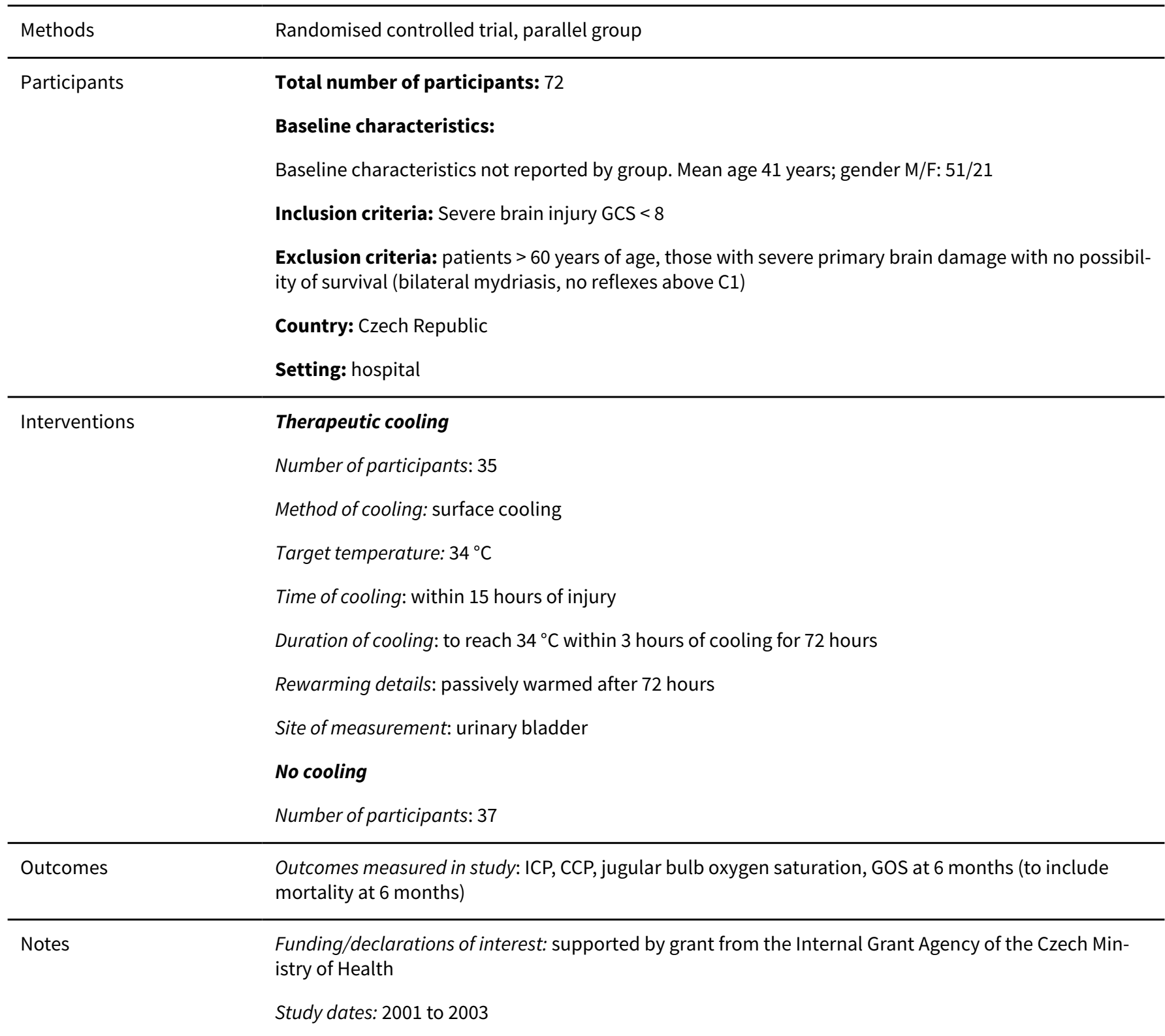

\section{Risk of bias}

\begin{tabular}{lll}
\hline Bias & Authors' judgement & Support for judgement \\
\hline $\begin{array}{l}\text { Random sequence genera- } \\
\text { tion (selection bias) }\end{array}$ & Unclear risk & Described as randomised; no additional details \\
\hline $\begin{array}{l}\text { Allocation concealment } \\
\text { (selection bias) }\end{array}$ & Unclear risk & No details \\
\hline $\begin{array}{l}\text { Blinding of participants } \\
\text { and personnel (perfor- } \\
\text { mance bias): mortality }\end{array}$ & Low risk & Lack of blinding unlikely to influence performance for this outcome \\
\hline $\begin{array}{l}\text { Blinding of participants } \\
\text { and personnel (perfor- } \\
\text { mance bias): GOS }\end{array}$ & Unclear risk & Unclear if lack of blinding likely to influence performance for this outcome \\
\hline \hline
\end{tabular}


Smrcka 2005 (Continued)

Blinding of outcome as- Low risk No details; lack of outcome assessor blinding is unlikely to influence outcome sessment (detection bias): data mortality; pneumonia

\begin{tabular}{lll}
\hline $\begin{array}{l}\text { Blinding of outcome as- } \\
\text { sessment (detection bias): } \\
\text { GOS }\end{array}$ & Unclear risk & No details \\
\hline $\begin{array}{l}\text { Incomplete outcome data } \\
\begin{array}{l}\text { (attrition bias) } \\
\text { All outcomes }\end{array}\end{array}$ & Low risk & No apparent losses \\
\hline $\begin{array}{l}\text { Selective reporting (re- } \\
\text { porting bias) }\end{array}$ & Unclear risk & $\begin{array}{l}\text { Clinical trials registration or pre-published protocol not reported. Insufficient } \\
\text { information to make judgement }\end{array}$ \\
\hline Other bias & Low risk & No other apparent sources of bias \\
\hline
\end{tabular}

\section{Wang 2005}

Methods Randomised controlled trial, parallel group

Participants

Total number of participants: 40

\section{Baseline characteristics:}

Baseline characteristics table not reported. Study authors state "no obvious differences in patients' condition such as age, sex, the level of ICP as well as other therapy between two groups"

Inclusion criteria: not reported. Severe brain injured participants with GCS $\leq 8$

Exclusion criteria: not reported

Country: China

Setting: hospital

\section{Therapeutic cooling}

Number of participants: 20

Method of cooling: water-circulating blankets placed above and below the body

Target temperature: 33.5 to $34.5^{\circ} \mathrm{C}$

Time of cooling: immediately

Duration of cooling: 2 days

Rewarming details: approximately $1{ }^{\circ} \mathrm{C}$ per day by continuous infusion of barbiturates $(2 \mathrm{mg} / \mathrm{kg} / \mathrm{h})$ to prevent shivering

Site of measurement: intracranial

\section{No cooling}

Number of participants: 20

Methods to maintain normothermia: barbiturates infused during initial 48 hours, followed by continuous infusion of barbiturates to prevent shivering 
Wang 2005 (Continued)

Target temperature: $37^{\circ} \mathrm{C}$

Outcomes Outcomes measured in study: changes in cerebrospinal fluid, cytokines, GOS at 6 months

Notes Funding/declarations of interest: not reported

Study dates: not reported

\section{Risk of bias}

\begin{tabular}{|c|c|c|}
\hline Bias & Authors' judgement & Support for judgement \\
\hline $\begin{array}{l}\text { Random sequence genera- } \\
\text { tion (selection bias) }\end{array}$ & Unclear risk & $\begin{array}{l}\text { Participants were described as "randomly divided" into groups. No additional } \\
\text { details }\end{array}$ \\
\hline $\begin{array}{l}\text { Allocation concealment } \\
\text { (selection bias) }\end{array}$ & Unclear risk & No details \\
\hline $\begin{array}{l}\text { Blinding of participants } \\
\text { and personnel (perfor- } \\
\text { mance bias): GOS }\end{array}$ & Unclear risk & No details. Unclear if lack of blinding may influence performance \\
\hline $\begin{array}{l}\text { Blinding of outcome as- } \\
\text { sessment (detection bias): } \\
\text { GOS }\end{array}$ & Unclear risk & No details. Unclear if lack of blinding may influence outcome assessment \\
\hline $\begin{array}{l}\text { Incomplete outcome data } \\
\text { (attrition bias) } \\
\text { All outcomes }\end{array}$ & Low risk & No losses \\
\hline $\begin{array}{l}\text { Selective reporting (re- } \\
\text { porting bias) }\end{array}$ & Unclear risk & $\begin{array}{l}\text { Clinical trials registration or pre-published protocol not reported. Insufficient } \\
\text { information to make judgement }\end{array}$ \\
\hline Other bias & Unclear risk & Limited detail in paper, not possible to judge other risks of bias \\
\hline
\end{tabular}

Yan 2001

\begin{tabular}{ll}
\hline Methods $\quad$ Randomised controlled trial, parallel group \\
\hline
\end{tabular}

Participants

\section{Total number of participants: 44}

\section{Baseline characteristics:}

\section{Therapeutic cooling}

Age: group A mean (SD) 47.0 ( \pm 18.8 ) years; group B mean (SD) $34.6( \pm 14)$ years

Gender M/F: 16/8

GCS on admission: group A mean (SD) $4.2( \pm 0.6)$; group B mean (SD) $7.2( \pm 0.8)$

Type of injury (closed/open): not stated

\section{No cooling}

Age: group A mean (SD) 43.3 ( \pm 15.8) years; group B mean (SD) $40.5( \pm 21)$ years

Gender M/F: 14/6 
Yan 2001 (Continued)

GCS on admission: group A mean (SD) 4.0 ( \pm 0.9); group B mean (SD) $7.6( \pm 0.4)$

Type of injury (closed/open): not stated

Inclusion criteria: GCS $<8$ on admission, arrived at hospital $<10$ hours after injury

Exclusion criteria: additional injuries or heart, lung, liver or kidney diseases

Country: China

Setting: ICU

Therapeutic cooling
Number of participants: 24
Method of cooling: cooling body surface with a cooling bed. Sometimes ice bricks placed on partici-
pant's neck, axilla or groin to aid cooling
Target temperature: 32 to $34^{\circ} \mathrm{C}$
Time of cooling: as quickly as possible after admission
Duration of cooling: 3 to 5 days
Rewarming details: cooling bed stopped and temperature resumed slowly and naturally
Site of measurement: rectal
No cooling
Number of participants: 20
Outcomes measured in study: evoked neural potentials, mortality
Funding/declarations of interest: no details
Study dates: May 1998 to April 1999
Note: groups initially divided into GCS 3 to 5 (Group A) and GCS 6 to 8 (Group B). Two sets of baseline
characteristics reported by Group A and Group B

\section{Risk of bias}

\begin{tabular}{lll}
\hline Bias & Authors' judgement & Support for judgement \\
\hline $\begin{array}{l}\text { Random sequence genera- } \\
\text { tion (selection bias) }\end{array}$ & Unclear risk & Described as randomly assigned; no additional details \\
\hline $\begin{array}{l}\text { Allocation concealment } \\
\text { (selection bias) }\end{array}$ & Unclear risk & Insufficient details \\
\hline
\end{tabular}

\begin{tabular}{lll}
$\begin{array}{l}\text { Blinding of participants } \\
\text { and personnel (perfor- } \\
\text { mance bias): mortality }\end{array}$ & Low risk & Lack of blinding unlikely to influence performance for this outcome \\
\hline $\begin{array}{l}\text { Blinding of outcome as- } \\
\text { sessment (detection bias): } \\
\text { mortality; pneumonia }\end{array}$ & Low risk & $\begin{array}{l}\text { No details; lack of outcome assessor blinding is unlikely to influence outcome } \\
\text { data }\end{array}$ \\
\hline
\end{tabular}

Incomplete outcome data Low risk No apparent losses
(attrition bias)


Yan 2001 (Continued)

All outcomes

\begin{tabular}{|c|c|c|}
\hline $\begin{array}{l}\text { Selective reporting (re- } \\
\text { porting bias) }\end{array}$ & Unclear risk & $\begin{array}{l}\text { Clinical trials registration or pre-published protocol not reported. Insufficient } \\
\text { information to make judgement }\end{array}$ \\
\hline
\end{tabular}

Other bias Low risk No other sources of bias identified

Yan 2010

\begin{tabular}{ll}
\hline Methods & Randomised controlled trial, parallel group \\
\hline Participants & Total number of participants: 148 \\
& Baseline characteristics: \\
& Baseline characteristics not reported by group. Overall mean participant age 27.3 years. 106 males, 42 \\
females & Inclusion criteria: severe traumatic brain injury (GCS $\leq 8)$, hospitalised within 10 hours of injury, $<65$ \\
& years of age, and had no other severe visceral injury, or heart, lung, liver, kidney or other visceral co- \\
morbidities & Exclusion criteria: no details \\
Country: China & Setting: ICU
\end{tabular}

Interventions

\section{Therapeutic cooling}

Number of participants: 73

Method of cooling method: medical cooling bed as soon as possible. Ice bags were placed on the neck, axilla, groin, and other regions

Target temperature: 32 to $34^{\circ} \mathrm{C}$

Time of cooling: following ICU admission, within 4 to 6 hours

Duration of cooling: 3 to 5 days

Rewarming details: following hypothermia treatment, the cooling bed was turned off and the participants regained normal body temperature

Site of temperature measurement: rectal

\section{No cooling}

Number of participants: 75

Target temperature: $37( \pm 0.5)^{\circ} \mathrm{C}$

Outcomes

Outcomes measured in study: GOS (time point not stated, "patients were followed up between 1 and 7 years"; to include mortality data), brain oxygen metabolism monitoring, neuro-electrophysiological monitoring

Notes

Funding/declarations of interest: supported by the scientific research foundation of Chongqing Municipal Health Bureau (1997 to 2005)

Study dates: June 1998 to June 2004 
Yan 2010 (Continued)

Note: participants divided into subgroups according to GCS. For this review, outcome data for groups have been combined

\section{Risk of bias}

\begin{tabular}{|c|c|c|}
\hline Bias & Authors' judgement & Support for judgement \\
\hline $\begin{array}{l}\text { Random sequence genera- } \\
\text { tion (selection bias) }\end{array}$ & Unclear risk & Described as randomly assigned; no additional details \\
\hline $\begin{array}{l}\text { Allocation concealment } \\
\text { (selection bias) }\end{array}$ & Unclear risk & No details \\
\hline $\begin{array}{l}\text { Blinding of participants } \\
\text { and personnel (perfor- } \\
\text { mance bias): mortality }\end{array}$ & Low risk & Lack of blinding unlikely to influence performance for this outcome \\
\hline $\begin{array}{l}\text { Blinding of participants } \\
\text { and personnel (perfor- } \\
\text { mance bias): GOS }\end{array}$ & Unclear risk & Unclear if lack of blinding likely to influence performance for this outcome \\
\hline $\begin{array}{l}\text { Blinding of outcome as- } \\
\text { sessment (detection bias): } \\
\text { mortality; pneumonia }\end{array}$ & Low risk & $\begin{array}{l}\text { No details; lack of outcome assessor blinding is unlikely to influence outcome } \\
\text { data }\end{array}$ \\
\hline $\begin{array}{l}\text { Blinding of outcome as- } \\
\text { sessment (detection bias): } \\
\text { GOS }\end{array}$ & Unclear risk & No details \\
\hline $\begin{array}{l}\text { Incomplete outcome data } \\
\text { (attrition bias) } \\
\text { All outcomes }\end{array}$ & Low risk & No apparent losses \\
\hline $\begin{array}{l}\text { Selective reporting (re- } \\
\text { porting bias) }\end{array}$ & Unclear risk & $\begin{array}{l}\text { Clinical trials registration or pre-published protocol not reported. Insufficient } \\
\text { information to make judgement }\end{array}$ \\
\hline Other bias & Unclear risk & Baseline characteristics not supplied. Unclear if groups are comparable \\
\hline
\end{tabular}

\section{Zhang 2000}

\begin{tabular}{ll}
\hline Methods & Randomised controlled trial, parallel group \\
\hline Participants & Total number of participants: 154 \\
& Baseline characteristics: \\
& Details taken from English abstract only; baseline characteristics not included \\
& Inclusion criteria: participants $<65$ years of age with traumatic brain injury and a GCS 3 to 8 on admis- \\
sion to hospital & Exclusion criteria: no details \\
Country: China & Setting: hospital
\end{tabular}


Zhang 2000 (Continued)

Number of participants: 77

Target temperature: 32 to $33^{\circ} \mathrm{C}$

Duration of cooling: 3 to 8 days

No cooling

Number of participants: 77

\begin{tabular}{ll}
\hline Outcomes & Outcomes measured in study: mortality \\
\hline Notes & Funding/declarations of interest: no details \\
& Study dates: not reported in abstract \\
& $\begin{array}{l}\text { Note: paper in Chinese. All data taken from English abstract. Data for severe head injury separated from } \\
\text { data for most severe head injury. In this review only data for 'severe' were recorded. Previous version of } \\
\text { review used data from both groups }\end{array}$
\end{tabular}

\section{Risk of bias}

\begin{tabular}{|c|c|c|}
\hline Bias & Authors' judgement & Support for judgement \\
\hline $\begin{array}{l}\text { Random sequence genera- } \\
\text { tion (selection bias) }\end{array}$ & Unclear risk & $\begin{array}{l}\text { Participants described as randomly divided; no additional details (abstract on- } \\
\text { ly) }\end{array}$ \\
\hline $\begin{array}{l}\text { Allocation concealment } \\
\text { (selection bias) }\end{array}$ & Unclear risk & No details (abstract only) \\
\hline $\begin{array}{l}\text { Blinding of participants } \\
\text { and personnel (perfor- } \\
\text { mance bias): mortality }\end{array}$ & Low risk & Lack of blinding unlikely to influence performance for this outcome \\
\hline $\begin{array}{l}\text { Blinding of outcome as- } \\
\text { sessment (detection bias): } \\
\text { mortality; pneumonia }\end{array}$ & Low risk & Lack of outcome assessor blinding is unlikely to influence outcome data \\
\hline $\begin{array}{l}\text { Incomplete outcome data } \\
\text { (attrition bias) } \\
\text { All outcomes }\end{array}$ & Low risk & Data presented for all randomised participants \\
\hline $\begin{array}{l}\text { Selective reporting (re- } \\
\text { porting bias) }\end{array}$ & Unclear risk & $\begin{array}{l}\text { Clinical trials registration or pre-published protocol not reported. Insufficient } \\
\text { information to make judgement }\end{array}$ \\
\hline Other bias & Unclear risk & $\begin{array}{l}\text { Insufficient information to make judgement on other sources of bias (abstract } \\
\text { only) }\end{array}$ \\
\hline
\end{tabular}

Zhao 2011

\begin{tabular}{ll}
\hline Methods & Randomised controlled trial, parallel design \\
\hline Participants & Total number of participants: 81 \\
& Baseline characteristics: \\
& Therapeutic cooling \\
& Age: mean (SD) $36.9( \pm 14.8)$ years \\
\hline
\end{tabular}


Zhao 2011 (Continued)

Gender M/F: 29/11

Type of injury (closed/open): closed

GCS on admission: GCS score 3 to 5: 15/40; GCS 6 to 8: 25/40

\section{No cooling}

Age: mean (SD) $37.5( \pm 15.2)$ years

Gender M/F: 30/11

Type of injury (closed/open): closed

GCS on admission: GCS 3 to 5: 16/41; GCS 6 to $8: 25 / 41$

Inclusion criteria: $>16$ years of age, admission within 6 hours of non-penetrating brain injury, GCS score 3 to 8 after resuscitation, no other chronic illnesses before the injury

Exclusion criteria: life-threatening injuries to other organs, or $\mathrm{SBP}<70 \mathrm{mmHg}$ after resuscitation

Country: China

Setting: hospital, neurosurgical wards

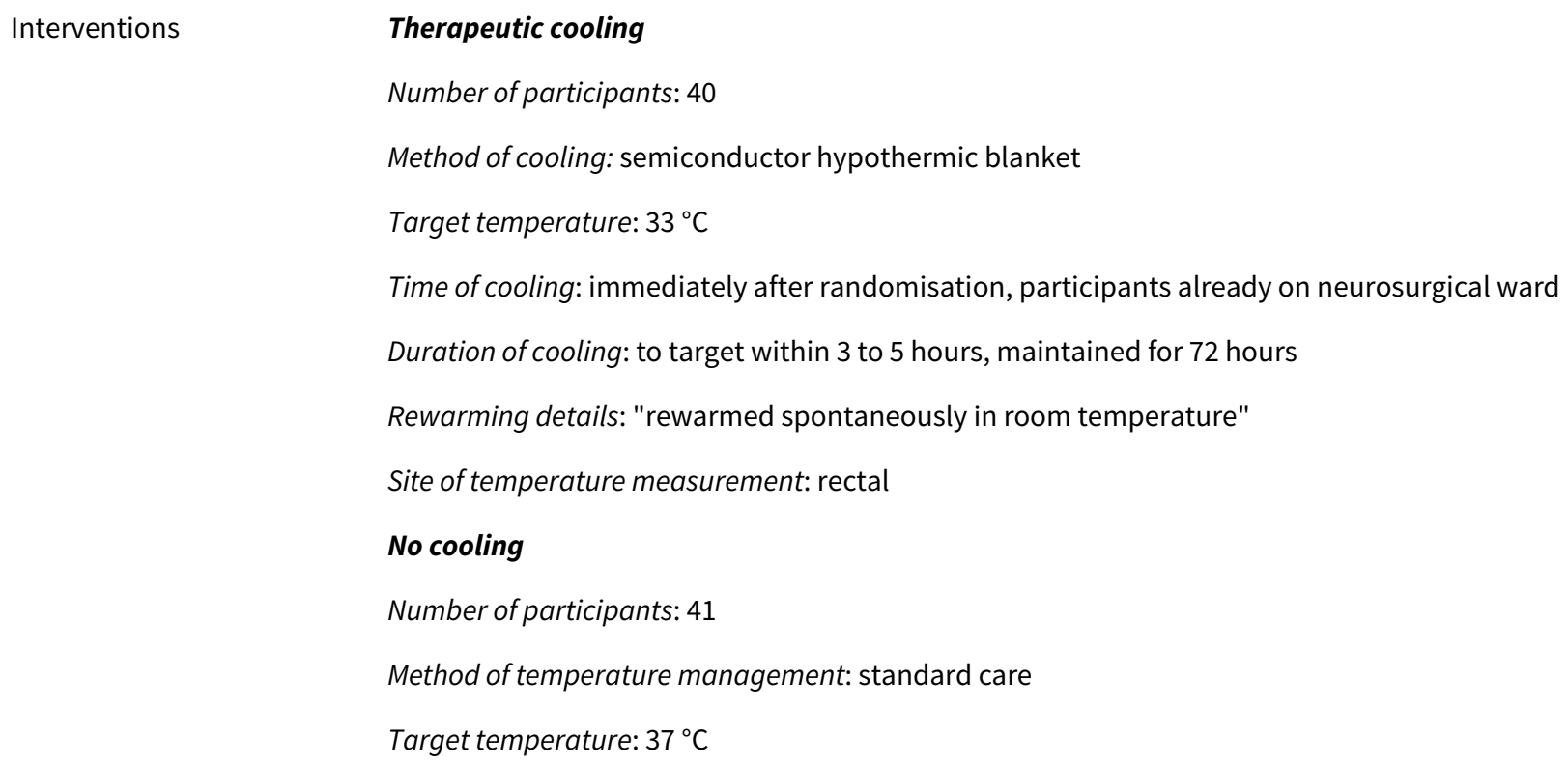

\section{Risk of bias}

\begin{tabular}{lll}
\hline Bias & Authors' judgement & Support for judgement \\
\hline $\begin{array}{l}\text { Random sequence genera- } \\
\text { tion (selection bias) }\end{array}$ & Unclear risk & Participants described as randomly allocated; no additional details \\
\hline
\end{tabular}


Zhao 2011 (Continued)

$\begin{aligned} & \text { Allocation concealment } \\ & \text { (selection bias) }\end{aligned}$
Unclear risk No details

\begin{tabular}{lll}
\hline Blinding of participants $\quad$ Low risk $\quad$ Not possible to blind personnel but unlikely to influence performance
\end{tabular}
and personnel (performance bias): mortality

$\begin{array}{ll}\text { Blinding of participants } & \text { Unclear risk } \\ \text { and personnel (perfor- } & \begin{array}{l}\text { Not possible to blind personnel but unclear if this would influence perfor- } \\ \text { mance }\end{array}\end{array}$
mance bias): GOS

Blinding of outcome as- Low risk Lack of outcome assessor blinding is unlikely to influence outcome data
sessment (detection bias):
mortality; pneumonia
mortality; pneumonia

$\begin{array}{ll}\text { Blinding of outcome as- } & \text { Unclear risk } \quad \text { No details } \\ \text { sessment (detection bias): } & \end{array}$

\section{GOS}

Incomplete outcome data Low risk No apparent loss to follow-up
(attrition bias)

All outcomes

\begin{tabular}{lll}
\hline $\begin{array}{l}\text { Selective reporting (re- } \\
\text { porting bias) }\end{array}$ & Unclear risk & $\begin{array}{l}\text { Clinical trials registration or pre-published protocol not reported. Insufficient } \\
\text { information to make judgement }\end{array}$ \\
\hline Other bias & Low risk & No other sources of bias identified \\
\hline
\end{tabular}

\section{Zhi 2003}

\begin{tabular}{ll}
\hline Methods & Randomised controlled trial, parallel group \\
\hline
\end{tabular}

\section{Participants}

\section{Total number of participants: 396}

\section{Baseline characteristics:}

Baseline characteristics table not reported. Study authors report "There was no statistical difference in clinical characteristics between the therapeutic and control group except the mean GCS score was higher in control group." Study report includes GCS for each group which appear comparable

\section{Therapeutic cooling}

Age: mean (SD) $43( \pm 17)$ years

GCS on admission: mean (SD) $5.8( \pm 1.8)$

\section{No cooling}

Age: mean (SD) $42( \pm 19)$ years

GCS on admission: mean (SD) $5.9( \pm 1.7)$

Inclusion criteria: participants with acute severe head injury $(\mathrm{GCS} \leq 8)$ within 24 hours of trauma, uncomplicated with major organ damage or functional failure, and without hypotension (SBP $\leq 90$ $\mathrm{mmHg}$ )

\section{Exclusion criteria: not reported}

Country: China 
Zhi 2003 (Continued)

Setting: hospital

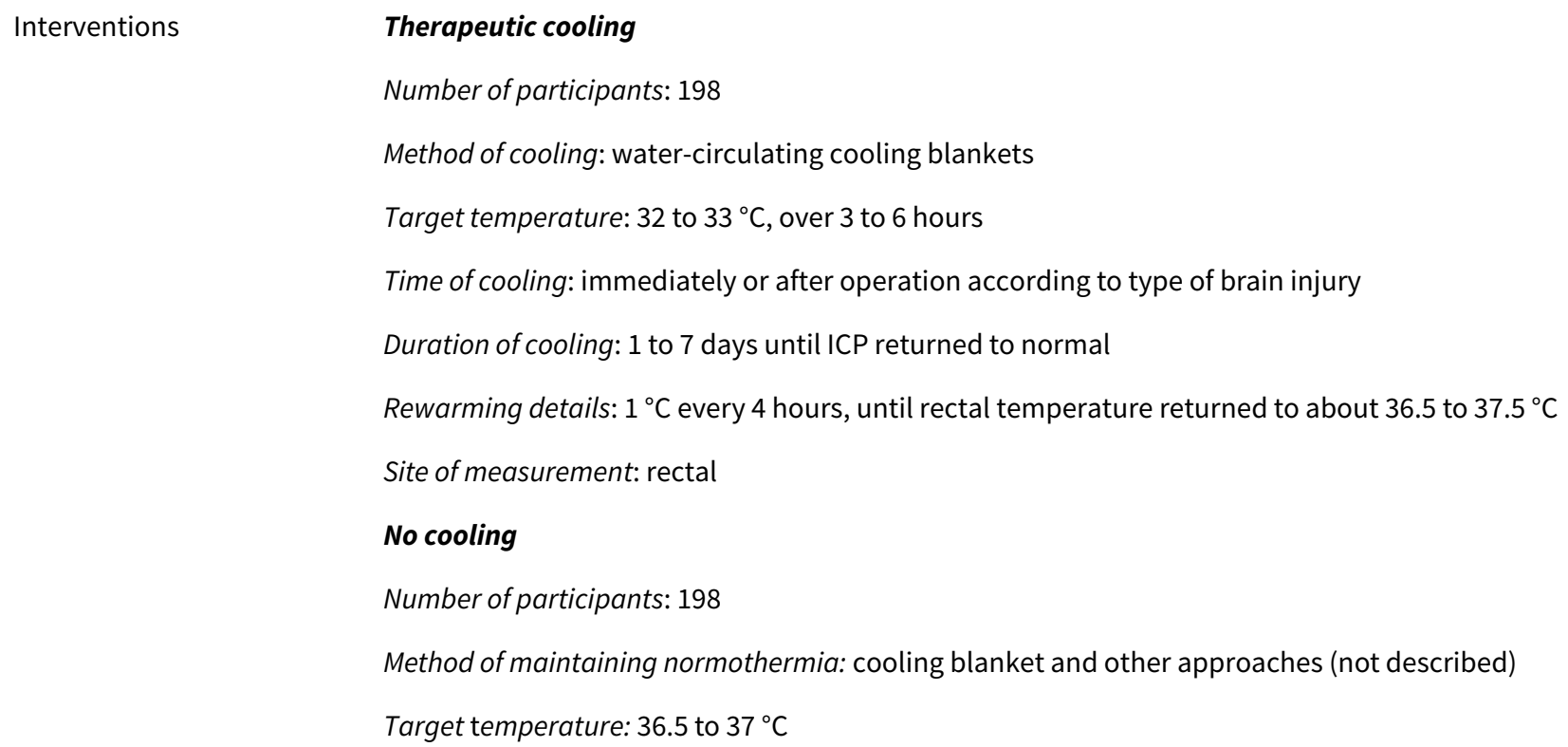

Note: some differences in total number of participants in the intervention group but appears to be a typo in the paper. We have used the number most frequently reported and which matches the number in the abstract

\section{Risk of bias}

\begin{tabular}{lll}
\hline Bias & Authors' judgement & Support for judgement \\
\hline $\begin{array}{l}\text { Random sequence genera- } \\
\text { tion (selection bias) }\end{array}$ & Unclear risk & Participants randomly assigned to groups; no additional details \\
\hline $\begin{array}{l}\text { Allocation concealment } \\
\text { (selection bias) }\end{array}$ & Unclear risk & No details \\
\hline $\begin{array}{l}\text { Blinding of participants } \\
\text { and personnel (perfor- } \\
\text { mance bias): mortality }\end{array}$ & Low risk & No details; lack of blinding unlikely to influence performance \\
\hline $\begin{array}{l}\text { Blinding of participants } \\
\text { and personnel (perfor- } \\
\text { mance bias): GOS }\end{array}$ & Unclear risk & No details; unclear if lack of blinding would influence performance \\
\hline $\begin{array}{l}\text { Blinding of outcome as- } \\
\text { sessment (detection bias): } \\
\text { mortality; pneumonia }\end{array}$ & Low risk & No details; lack of blinding unlikely to influence outcome assessment \\
\hline $\begin{array}{l}\text { Blinding of outcome as- } \\
\text { sessment (detection bias): } \\
\text { GOS }\end{array}$ & Unclear risk & No details; unclear if lack of blinding would influence outcome assessment \\
\hline
\end{tabular}


Zhi 2003 (Continued)
Incomplete outcome data
Low risk
No apparent losses
(attrition bias)

All outcomes

\begin{tabular}{lll}
\hline $\begin{array}{l}\text { Selective reporting (re- } \\
\text { porting bias) }\end{array}$ & Unclear risk & $\begin{array}{l}\text { Clinical trials registration or pre-published protocol not reported. Insufficient } \\
\text { information to make judgement }\end{array}$ \\
\hline Other bias & Low risk & No other source of bias identified
\end{tabular}

$\mathrm{AVDO}_{2}=$ arterio jugular venous difference of oxygen; $\mathrm{CPP}=$ cerebral perfusion pressure; $\mathrm{CSF}=$ cerebrospinal fluid; $\mathrm{CT}=$ computed tomography; DBP = diastolic blood pressure; GCS = Glasgow Coma Scale; GOS = Glasgow Outcome Score; GOS-E-Peds = extended paediatric Glasgow Outcome Score; ICP = intracranial pressure; ICU = intensive care unit; IQR = interquartile range; IV = intravenous; MAP = mean arterial pressure; $\mathrm{M} / \mathrm{F}=$ male/female; $\mathrm{n}=$ number of participants; $\mathrm{PICU}=$ paediatric intensive care unit; $\mathrm{PT} / \mathrm{PTT}=$ prothrombin time/partial thromboplastin time; $\mathrm{P}_{\mathrm{ti}} \mathrm{O}_{2}$ = brain tissue oxygen; $\mathrm{SBP}=$ systolic blood pressure; $\mathrm{SD}=$ standard deviation

Characteristics of excluded studies [ordered by study ID]

\begin{tabular}{ll}
\hline Study & Reason for exclusion \\
\hline ACTRN12615001119583p & Registered ongoing feasibility study. Wrong intervention. Aim to maintain temperature at $36^{\circ} \mathrm{C}$ \\
\hline Maekawa 2015 & $\begin{array}{l}\left.\text { Therapeutic hypothermia }\left(32 \text { to } 34^{\circ} \mathrm{C}\right) \text { compared with 'fever control' (35.5 to } 37^{\circ} \mathrm{C}\right) . \text { No normother- } \\
\text { mia group }\end{array}$ \\
\hline Meissner 1998 & Abstract only. Does not appear to be an RCT \\
\hline NCT01333488 & $\begin{array}{l}\text { Registered study in clinical trials register. Terminated early due to inadequate accrual. Data for } \\
\text { comparison arm with only } 3 \text { participants }\end{array}$ \\
\hline NCT02353793 & \begin{tabular}{l} 
Registered ongoing study. Traumatised participants, not specifically brain-injury patients \\
\hline Rincon 2014
\end{tabular} \\
\hline Participants with intracerebral haemorrhage \\
\hline $\begin{array}{l}\text { Participants with traumatic brain injury randomly divided into hypothermic group or control } \\
\text { group. Study objective to assess effect of hypothermia on glucose metabolism and glycerol of brain } \\
\text { tissue. No relevant outcomes. Excluded as no details of methods used to induce hypothermia, } \\
\text { number of participants per group not reported, and some participants appear not to be included } \\
\text { for full study }\end{array}$ \\
\hline Yan 2007 & $\begin{array}{l}\text { English abstract does not report any relevant outcomes. We have not sought translation of full re- } \\
\text { port }\end{array}$ \\
\hline
\end{tabular}

$\mathrm{RCT}=$ randomised controlled trial

Characteristics of studies awaiting assessment [ordered by study ID]

Gál 2012

\begin{tabular}{ll}
\hline Methods & Randomised controlled trial, parallel group \\
\hline Participants & Patients with GCS 4 to 8; admitted to hospital from 2002 to 2006 \\
\hline
\end{tabular}

Interventions Therapeutic cooling

Number of participants: 47 
Gál 2012 (Continued)

Method of cooling: water mattress cooling

Target temperature: $34^{\circ} \mathrm{C}$

Duration of cooling: 72 hours

Rewarming details: slowly to temperature of $36.5^{\circ} \mathrm{C}$

\section{No cooling}

Number of participants: 53

Target temperature: 36.5 to $37.5^{\circ} \mathrm{C}$

\section{Outcomes}

GOS

Notes Abstract. Possibly associated with Smrcka 2005. Email sent to authors for further information

Tang 2017

\begin{tabular}{ll}
\hline Methods & Randomised controlled trial, parallel group \\
\hline Participants & $\begin{array}{l}\text { Patients with primary, closed traumatic brain injury, ICP }>20 \text { mmHg after decompressive craniec- } \\
\text { tomy, }>16 \text { years of age, men or nonpregnant women, clear history of head injury, GCS } 3 \text { to } 8 \text { on ad- } \\
\text { mission or after resuscitation, availability of a cooling device or technique for }>72 \text { hours, brain in- } \\
\text { jury confirmed by sequential computed tomography scanning within } 6 \text { hours of injury }\end{array}$ \\
\hline
\end{tabular}

Interventions

\section{Therapeutic cooling}

Number of participants: 30

Method of cooling: water-circulating cooling blanket

Target temperature: 32 to $35^{\circ} \mathrm{C}$

Duration of cooling: 48 hours

Rewarming details: after 48 hours at a rate of $0.25^{\circ} \mathrm{C}$ per hour

\section{No cooling}

Number of participants: 30

Target temperature: $\geq 36^{\circ} \mathrm{C}$

\begin{tabular}{ll}
\hline Outcomes & GOS, MAP, CPP, temperature, complications \\
\hline Notes & $\begin{array}{l}\text { Study identified during pre-publication search in June 2017; to be incorporated into review at next } \\
\text { formal update }\end{array}$ \\
\hline
\end{tabular}

$\mathrm{CPP}=$ cerebral perfusion pressure; GCS = Glasgow Coma Score; GOS = Glasgow Outcome Scale; ICP = intracranial pressure; MAP = mean arterial pressure

Characteristics of ongoing studies [ordered by study ID]

\section{Lei 2015}

Trial name or title

Rationale, methodology, and implementation of a nationwide multicenter randomised controlled trial of long-term mild hypothermia for severe traumatic brain injury (the LTH-1 trial) 
Lei 2015 (Continued)

Methods $\quad$ Randomised controlled trial, parallel group
Inclusion criteria: closed brain injury within 6 hours of arrival at hospital, 18 to 65 years of age, GCS of 4 to 8 on admission or after resuscitation, abnormal images on initial CT scan, ICP $>25$ $\mathrm{mmHg}$

Exclusion criteria: severely combined injury or life-threatening injury to other organs, preexisting medical conditions such as severe heart disease, systolic blood pressure $<90 \mathrm{mmHg}$ or oxygen saturation $<94 \%$ after resuscitation, pregnant or breastfeeding women, lack of consent

\section{Therapeutic cooling}

Method of cooling: cooling blankets

Target temperature: $34^{\circ} \mathrm{C}$

Time of cooling: immediately

Duration of cooling: 5 days

Rewarming details: $0.5^{\circ} \mathrm{C}$ every 4 hours

Site of measurement: rectal

\section{No cooling}

Target temperature: 36 to $37^{\circ} \mathrm{C}$

\section{Outcomes}

GOS at 6 months, GOS at 1 month, mortality at 6 months, length of ICU and hospital stay, ICP, GCS during 6 months follow-up, complications (neurological, infectious, cardiovascular, coagulation and bleeding, miscellaneous)

\begin{tabular}{ll}
\hline Starting date & July 2013 \\
\hline Contact information & doctorjinlei@163.com \\
\hline Notes & Registered trial ID: NCT01886222
\end{tabular}

\section{Nichol 2015}

$\begin{array}{ll}\text { Trial name or title } & \begin{array}{l}\text { Protocol for a multicentre randomised controlled trial of early and sustained prophylactic hy- } \\ \text { pothermia in the management of traumatic brain injury }\end{array}\end{array}$

Methods Randomised controlled trial, parallel group

Participants

Inclusion criteria: blunt trauma, clinical diagnosis of severe traumatic brain injury, GCS $<9, \geq 18$ and $\leq 60$ years of age, patient is intubated or intubation is imminent

Exclusion criteria: clinical diagnosis of drug or alcohol intoxication predominant cause of coma, randomisation not possible within 3 hours of injury, able to be intubated without drugs, persistent $\mathrm{SBP}<90 \mathrm{mmHg}$, cardiac arrest, GCS $=3$ and unreactive pupils, clinically significant bleeding likely to require haemostatic intervention, penetrating neck or torso injury, pregnancy, current anticoagulant treatment, existing neurological condition, cooling not in the best interest of the patient according to treating clinician

\section{Interventions Therapeutic cooling}

Method of cooling: bolus infusion of cold IV fluids and exposure, then cooling with refrigerated water blankets and vests 
Nichol 2015 (Continued)

\author{
Target temperature: $33^{\circ} \mathrm{C}$ \\ Time of cooling: within 3 hours of injury \\ Duration of cooling: 72 hours \\ Rewarming details: $0.5^{\circ} \mathrm{C}$ every 3 hours \\ No cooling
}

Target temperature: 36.5 to $37.5^{\circ} \mathrm{C}$

\begin{tabular}{ll}
\hline Outcomes & $\begin{array}{l}\text { GOS-E at } 6 \text { months, quality of life assessment, all-cause mortality at hospital discharge and } 6 \\
\text { months, adverse events (bleeding and infections), health economic evaluation }\end{array}$ \\
\hline Starting date & April 2010 \\
\hline Contact information & jamie.cooper@monash.edu \\
\hline Notes & Registered trial ID: NCT00987688 \\
\hline
\end{tabular}

$\mathrm{CT}$ = computed tomography; GCS = Glasgow Coma Scale; GOS = Glasgow Outcome Score; GOS-E - Glasgow Outcome Score - Extended; ICP = intracranial pressure; ICU = intensive care unit; IV = intravenous; $\mathrm{SBP}=$ systolic blood pressure

\title{
DATA AND ANALYSES
}

Comparison 1. Therapeutic cooling versus no cooling

\begin{tabular}{lllll}
\hline $\begin{array}{l}\text { Outcome or subgroup } \\
\text { title }\end{array}$ & No. of studies & $\begin{array}{l}\text { No. of partici- } \\
\text { pants }\end{array}$ & Statistical method & Effect size \\
\hline 1 Mortality & 32 & Odds Ratio (M-H, Fixed, $95 \% \mathrm{Cl})$ & Subtotals only \\
\hline 2 Unfavourable outcome & 27 & Odds Ratio (M-H, Fixed, $95 \% \mathrm{Cl})$ & Subtotals only \\
\hline 3 Pneumonia & 12 & Odds Ratio (M-H, Fixed, $95 \% \mathrm{Cl})$ & Subtotals only \\
\hline
\end{tabular}

Analysis 1.1. Comparison 1 Therapeutic cooling versus no cooling, Outcome 1 Mortality.

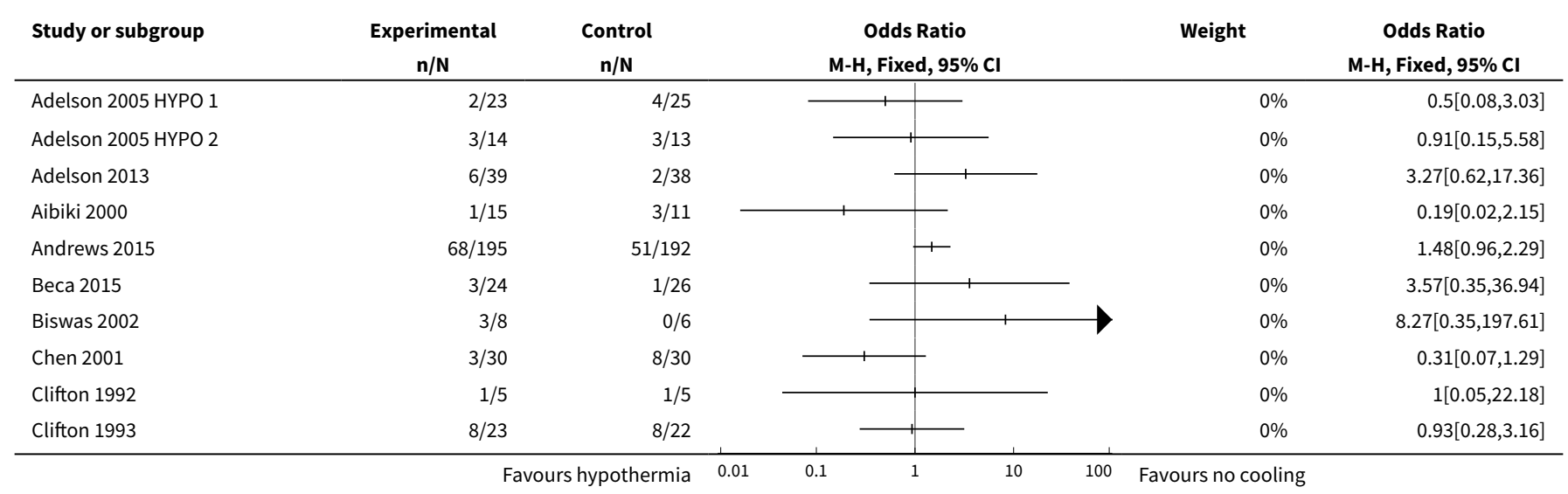




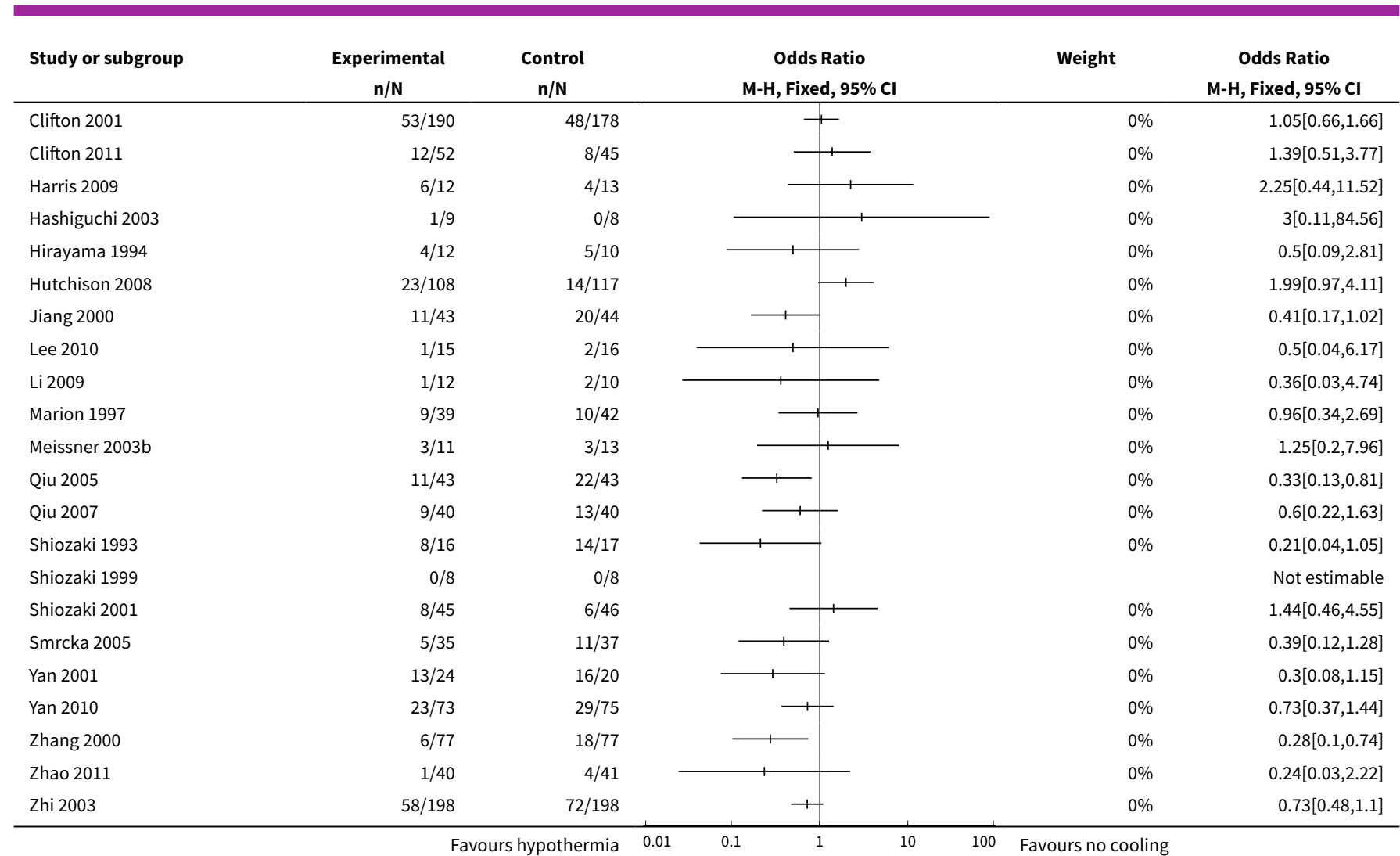

\section{Analysis 1.2. Comparison 1 Therapeutic cooling versus no cooling, Outcome 2 Unfavourable outcome.}

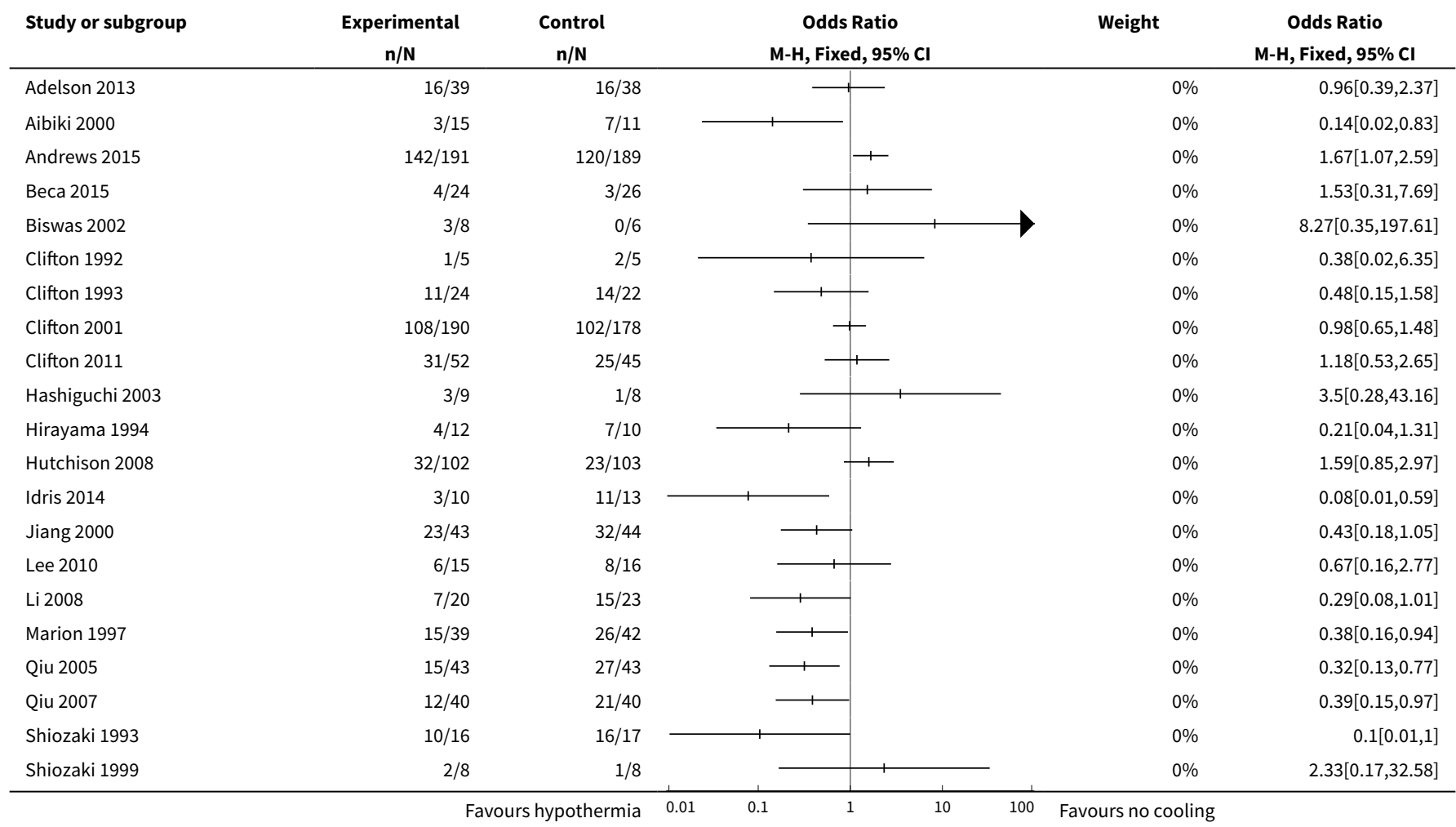




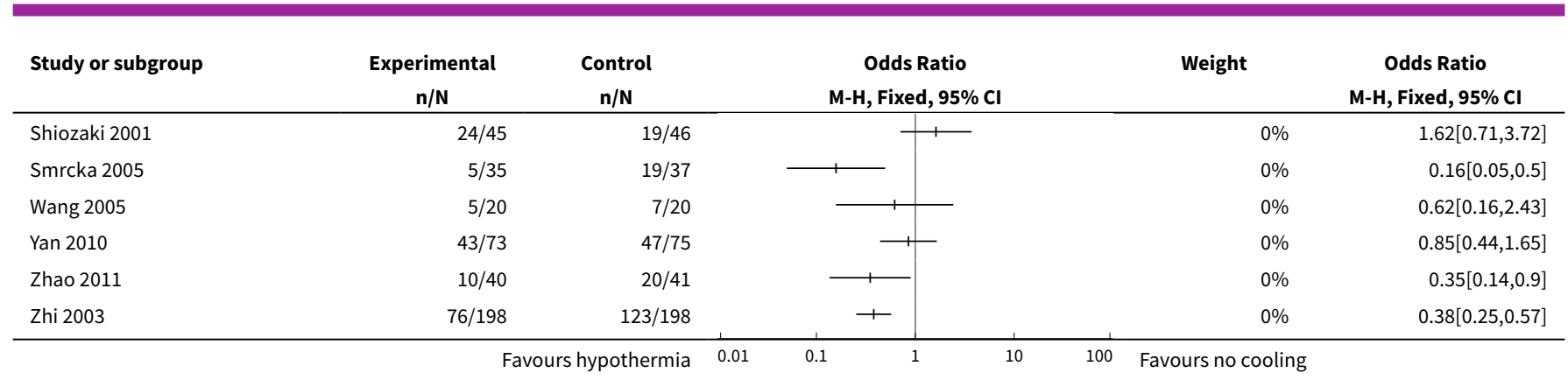

Analysis 1.3. Comparison 1 Therapeutic cooling versus no cooling, Outcome 3 Pneumonia.

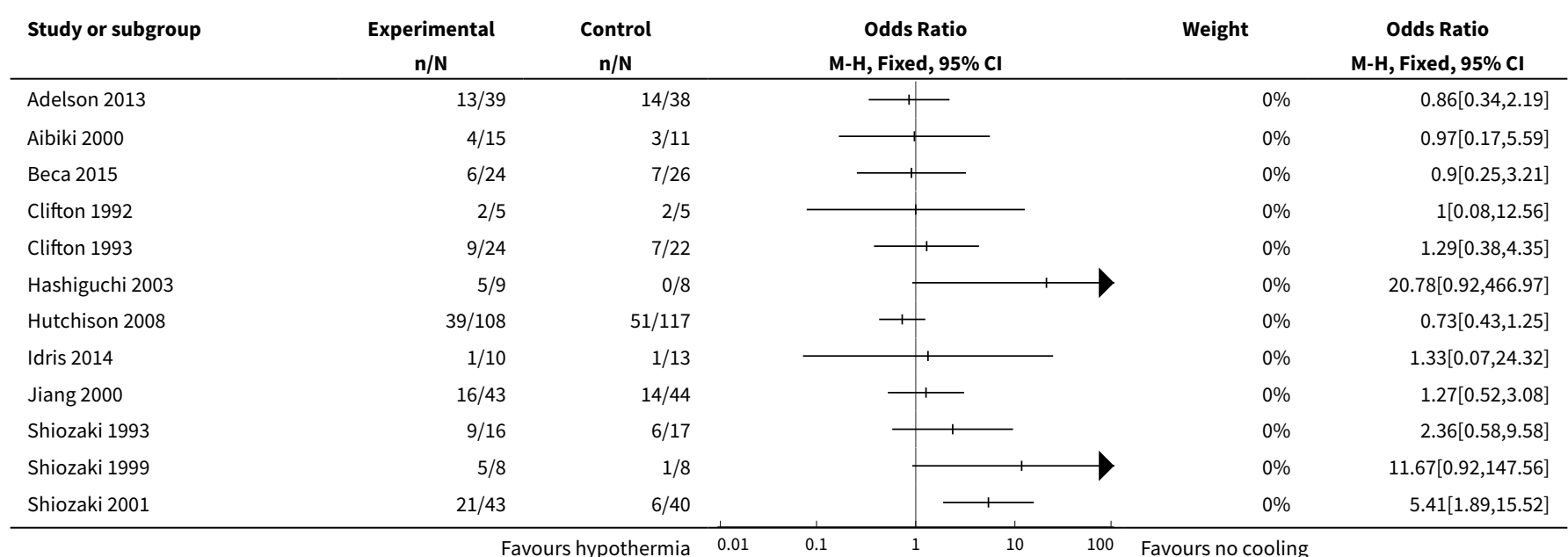

\section{Comparison 2. Therapeutic cooling versus no cooling: by duration}

\begin{tabular}{lllll}
\hline $\begin{array}{l}\text { Outcome or subgroup } \\
\text { title }\end{array}$ & No. of studies & $\begin{array}{l}\text { No. of partici- } \\
\text { pants }\end{array}$ & Statistical method & Effect size \\
\hline 1 Mortality & 32 & Odds Ratio $(\mathrm{M}-\mathrm{H}$, Fixed, $95 \% \mathrm{Cl})$ & Totals not selected \\
\hline 1.124 hours & 4 & Odds Ratio $(\mathrm{M}-\mathrm{H}$, Fixed, $95 \% \mathrm{Cl})$ & $0.0[0.0,0.0]$ \\
\hline 1.2 More than 24 hours & 28 & Odds Ratio $(\mathrm{M}-\mathrm{H}$, Fixed, $95 \% \mathrm{Cl})$ & $0.0[0.0,0.0]$ \\
\hline $\begin{array}{l}2 \text { Unfavourable out- } \\
\text { come }\end{array}$ & 26 & Odds Ratio $(\mathrm{M}-\mathrm{H}$, Fixed, $95 \% \mathrm{Cl})$ & Totals not selected \\
\hline 2.124 hours & 3 & Odds Ratio $(\mathrm{M}-\mathrm{H}$, Fixed, $95 \% \mathrm{Cl})$ & $0.0[0.0,0.0]$ \\
\hline 2.2 More than 24 hours & 23 & Odds Ratio $(\mathrm{M}-\mathrm{H}$, Fixed, $95 \% \mathrm{Cl})$ & $0.0[0.0,0.0]$ \\
\hline 3 Pneumonia & 12 & Odds Ratio $(\mathrm{M}-\mathrm{H}$, Fixed, $95 \% \mathrm{Cl})$ & Totals not selected \\
\hline 3.124 hours & 2 & Odds Ratio $(\mathrm{M}-\mathrm{H}$, Fixed, $95 \% \mathrm{Cl})$ & $0.0[0.0,0.0]$ \\
\hline 3.2 More than 24 hours & 10 & Odds Ratio $(\mathrm{M}-\mathrm{H}$, Fixed, $95 \% \mathrm{Cl})$ & $0.0[0.0,0.0]$ \\
\hline \hline
\end{tabular}


Analysis 2.1. Comparison 2 Therapeutic cooling versus no cooling: by duration, Outcome 1 Mortality.

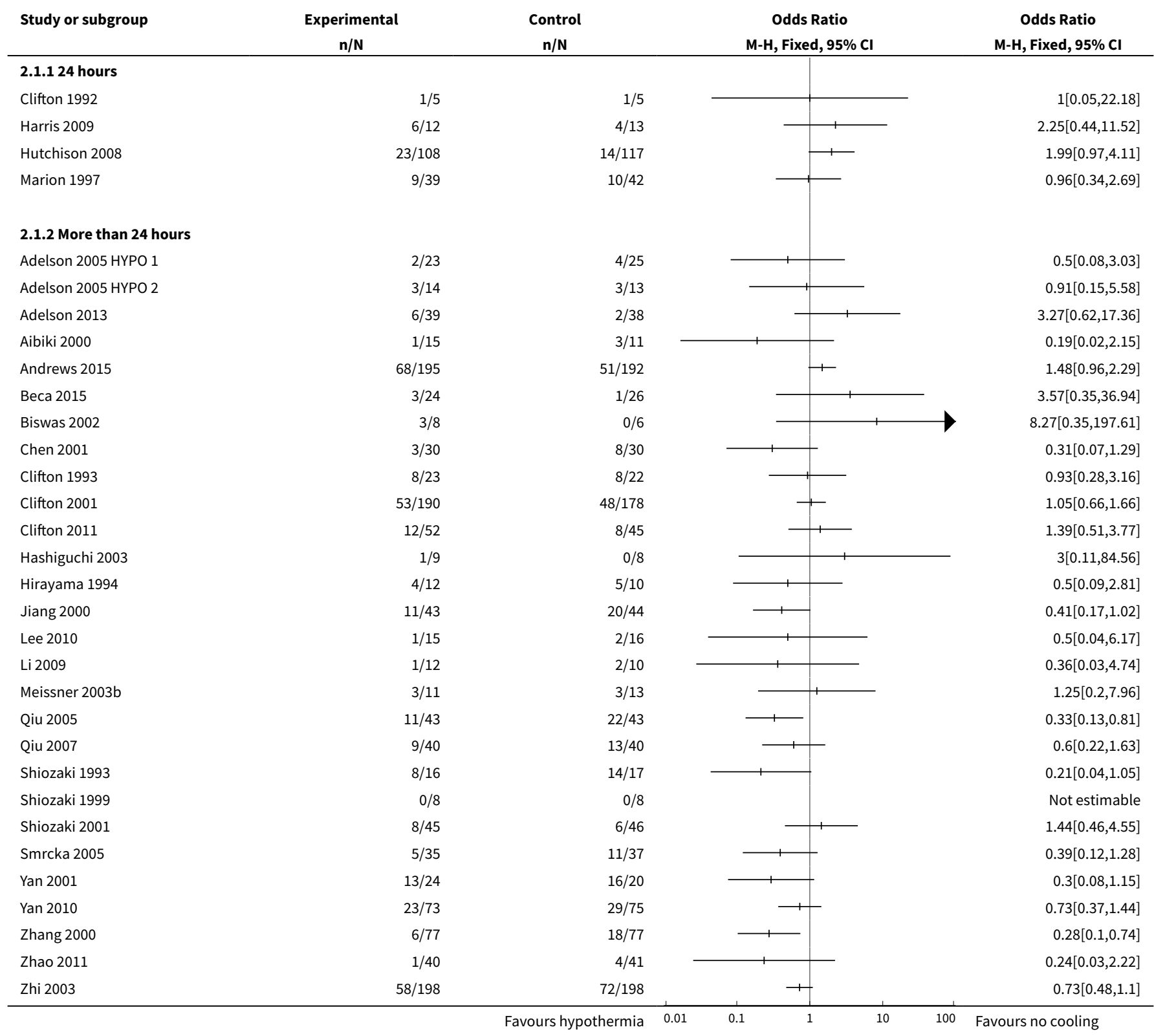

Analysis 2.2. Comparison 2 Therapeutic cooling versus no cooling: by duration, Outcome 2 Unfavourable outcome.

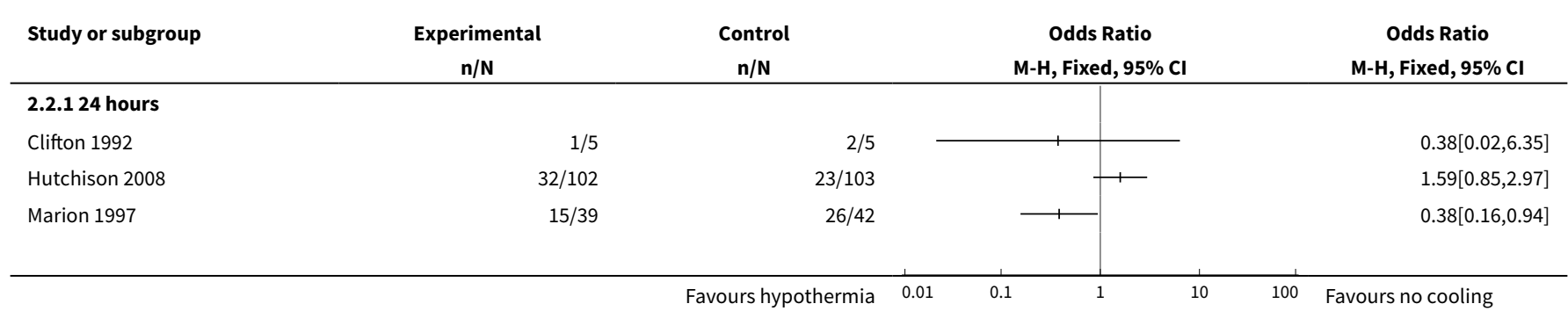




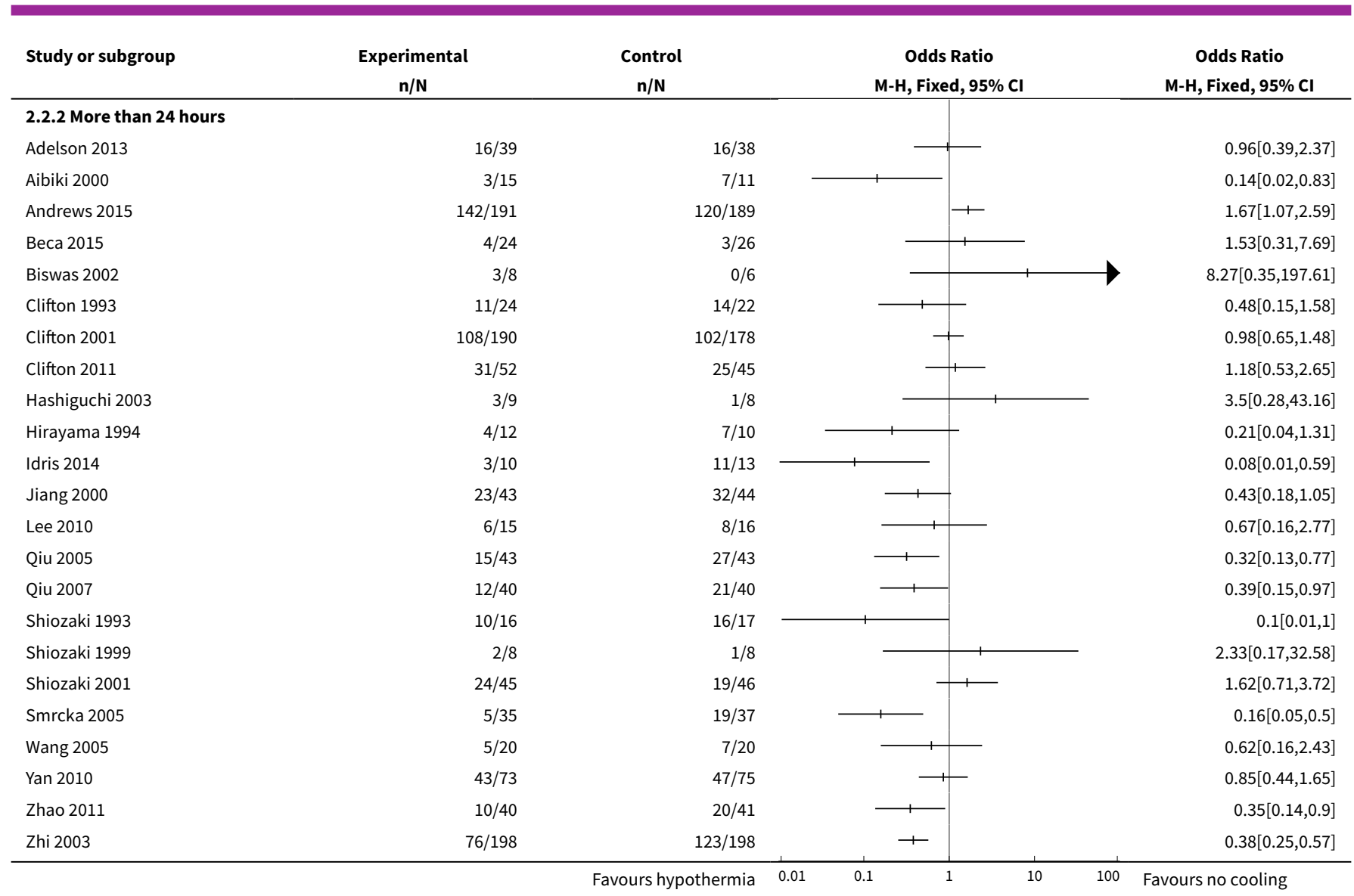

Analysis 2.3. Comparison 2 Therapeutic cooling versus no cooling: by duration, Outcome 3 Pneumonia.

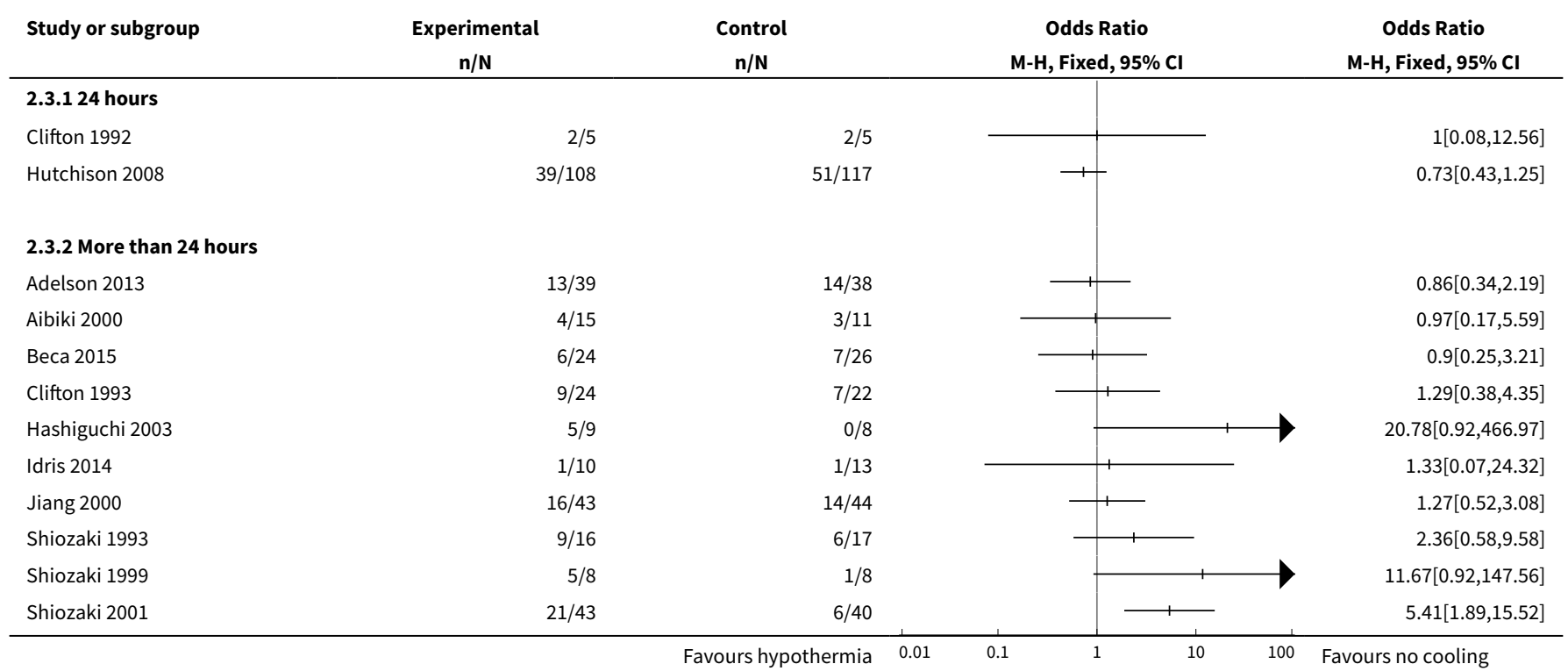


Comparison 3. Therapeutic cooling versus no cooling: by length of follow-up

\begin{tabular}{|c|c|c|c|c|}
\hline $\begin{array}{l}\text { Outcome or subgroup } \\
\text { title }\end{array}$ & No. of studies & $\begin{array}{l}\text { No. of partici- } \\
\text { pants }\end{array}$ & Statistical method & Effect size \\
\hline 1 Mortality & 32 & & Risk Ratio (IV, Fixed, 95\% CI) & Totals not selected \\
\hline 1.1 One month & 13 & & Risk Ratio (IV, Fixed, 95\% CI) & $0.0[0.0,0.0]$ \\
\hline 1.2 Three months & 6 & & Risk Ratio (IV, Fixed, 95\% CI) & $0.0[0.0,0.0]$ \\
\hline 1.3 Six months & 14 & & Risk Ratio (IV, Fixed, 95\% CI) & $0.0[0.0,0.0]$ \\
\hline $\begin{array}{l}1.4 \text { Twelve months or } \\
\text { more }\end{array}$ & 7 & & Risk Ratio (IV, Fixed, 95\% CI) & $0.0[0.0,0.0]$ \\
\hline $\begin{array}{l}2 \text { Unfavourable out- } \\
\text { come }\end{array}$ & 26 & & Risk Ratio (IV, Fixed, 95\% CI) & Totals not selected \\
\hline 2.1 Three months & 9 & & Risk Ratio (IV, Fixed, 95\% CI) & $0.0[0.0,0.0]$ \\
\hline 2.2 Six months & 15 & & Risk Ratio (IV, Fixed, 95\% CI) & $0.0[0.0,0.0]$ \\
\hline 2.3 Twelve months & 6 & & Risk Ratio (IV, Fixed, 95\% CI) & $0.0[0.0,0.0]$ \\
\hline
\end{tabular}

Analysis 3.1. Comparison 3 Therapeutic cooling versus no cooling: by length of follow-up, Outcome 1 Mortality.

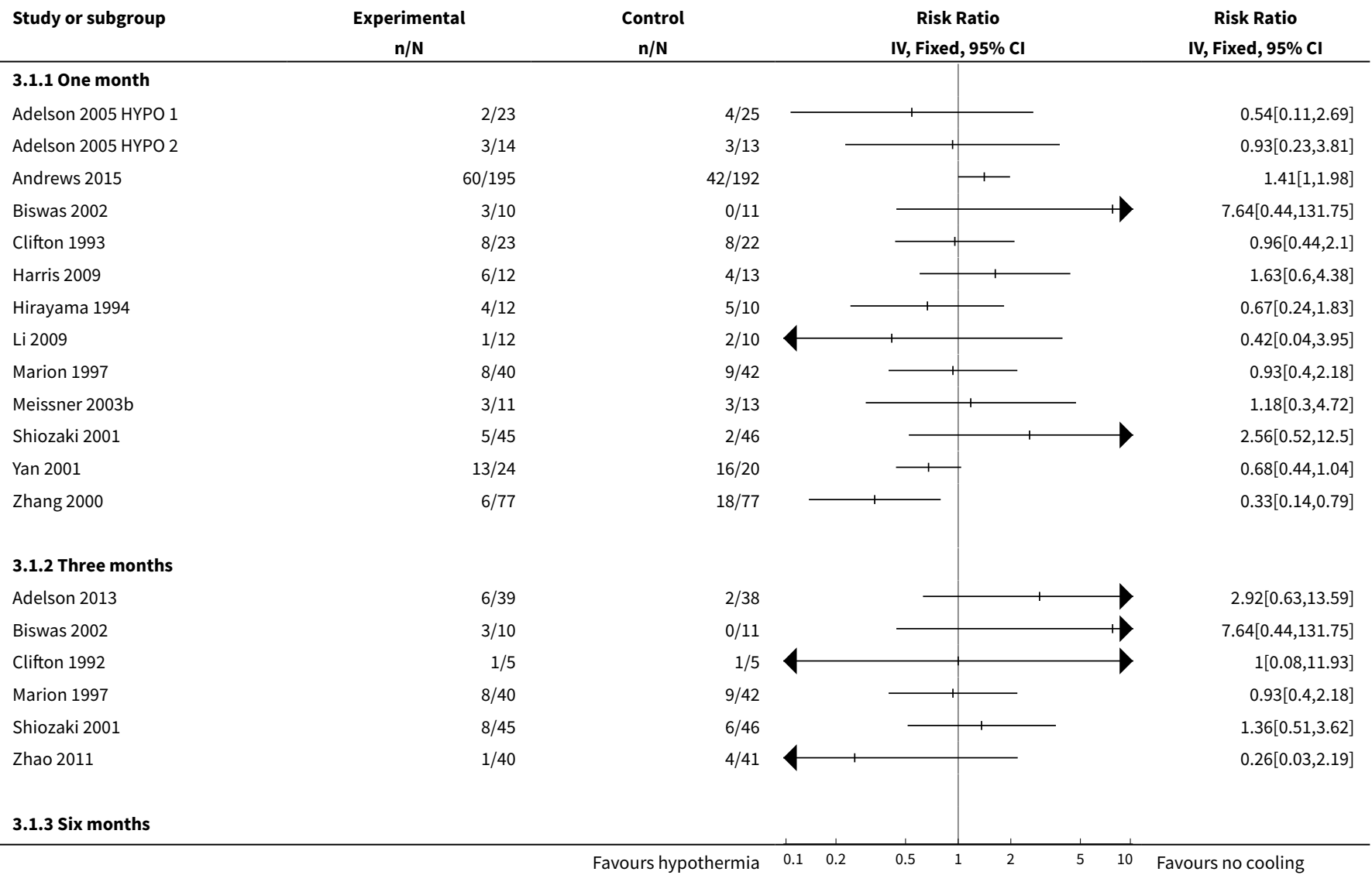




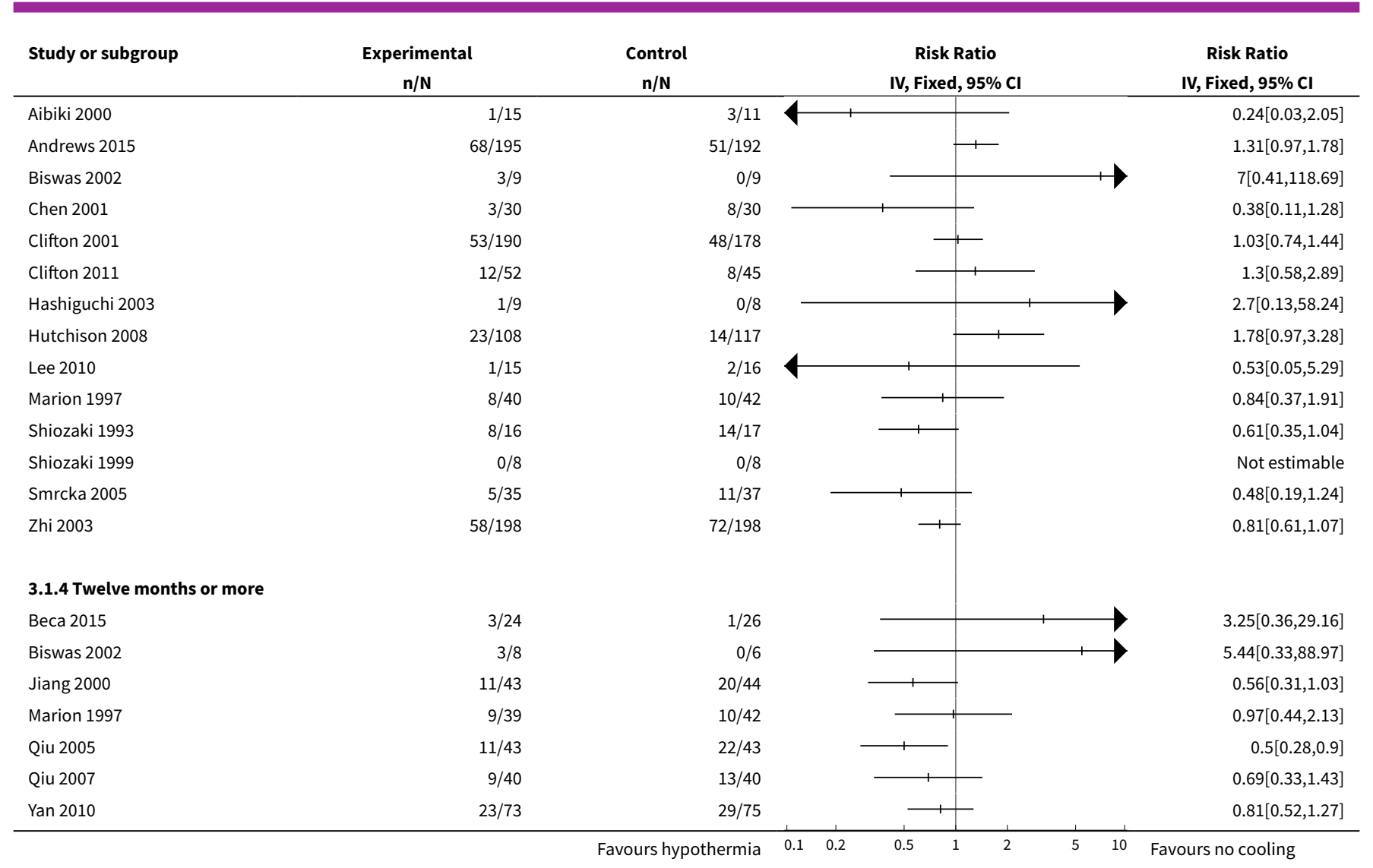

Analysis 3.2. Comparison 3 Therapeutic cooling versus no cooling: by length of follow-up, Outcome 2 Unfavourable outcome.

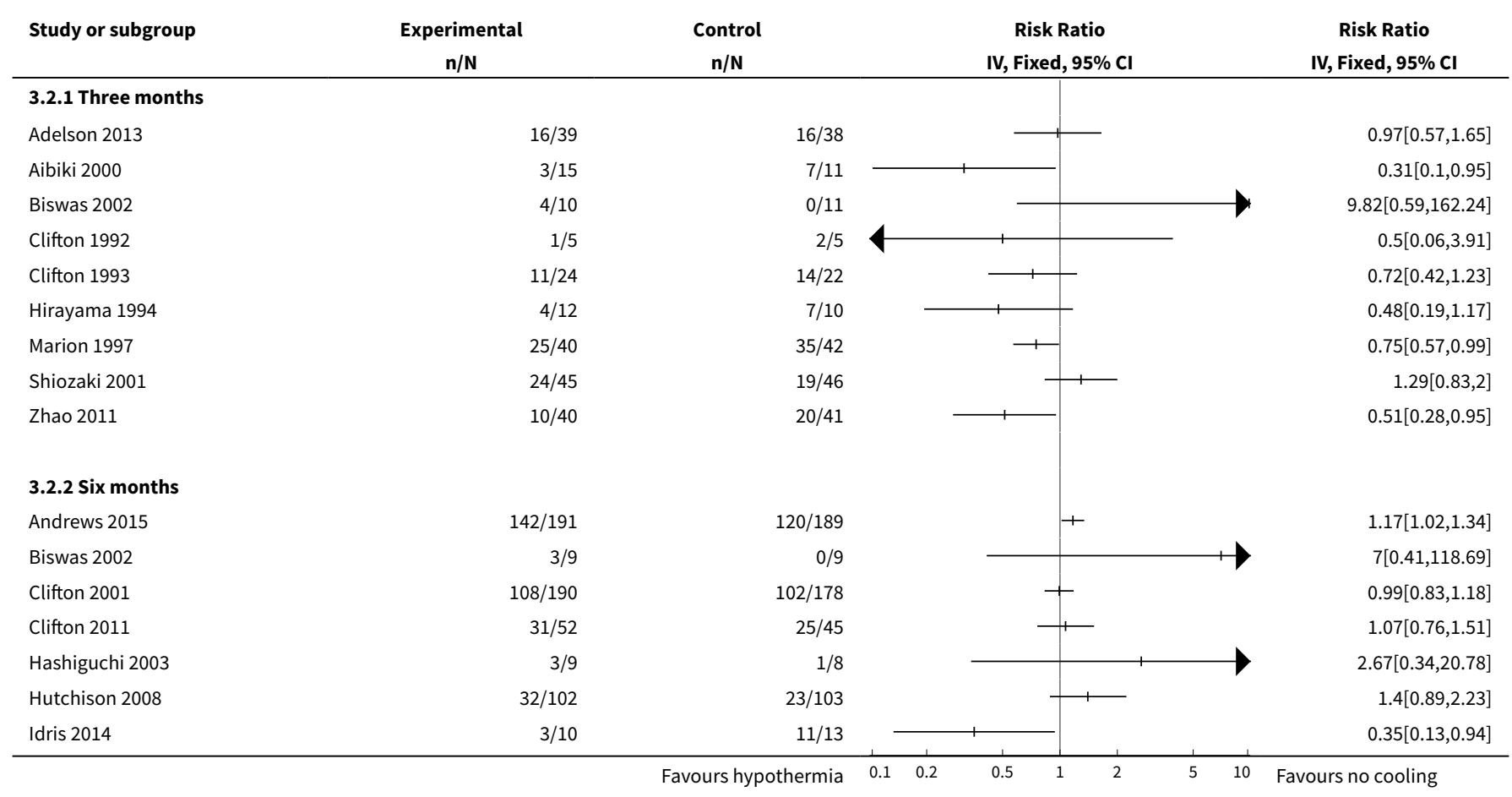




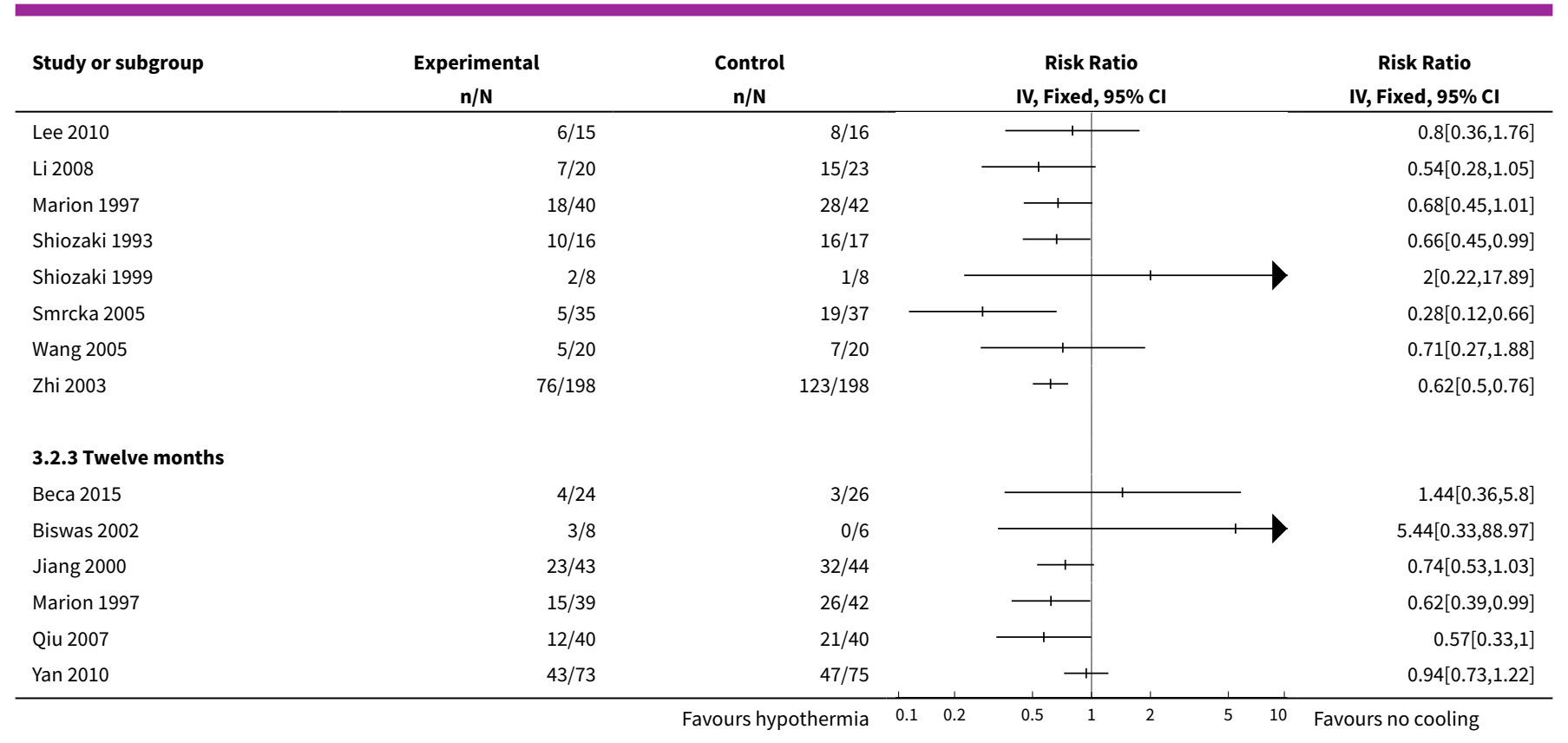

\section{APPENDICES}

\section{Appendix 1. Search strategies 2016 and 2017}

The search strategies for the 2017 update were slightly modified because the search interfaces on some of the databases have changed since the last update in 2009 , however the search terms remain unchanged.

The search of the clinical trials registers was not limited by date as the search terms used previously were not reported and it was unclear how the registers were searched, the search strings are now reported in full in this appendix.

Studies identified from searches to March 2016 have been incorporated in this review, a study identified from a pre-publication search (1 June 2017) is presented in Studies awaiting classification.

Cochrane Injuries Group Specialised Register and Cochrane Central Register of Controlled Trials (CENTRAL, the Cochrane Library) Issue 6, 2017

\#1MESH DESCRIPTOR Craniocerebral Trauma EXPLODE ALL TREES

\#2MESH DESCRIPTOR Cerebrovascular Trauma EXPLODE ALL TREES

\#3MESH DESCRIPTOR Brain Edema EXPLODE ALL TREES

\#4((brain or cerebral or intracranial) near3 (oedema or edema or swell $\left.\left.{ }^{\star}\right)\right): \mathrm{TI}, \mathrm{AB}, \mathrm{KY}$

\#5MESH DESCRIPTOR Glasgow Coma Scale EXPLODE ALL TREES

\#6MESH DESCRIPTOR Glasgow Outcome Scale EXPLODE ALL TREES

\#7MESH DESCRIPTOR Unconsciousness EXPLODE ALL TREES

\#8(glasgow near3 (coma or outcome) near3 (score or scale)):TI,AB,KY

\#9((Unconscious ${ }^{\star}$ or coma* or concuss ${ }^{*}$ or 'persistent vegetative state') near3 (injur ${ }^{\star}$ or trauma* or damag* or wound ${ }^{\star}$ or $^{*}$ fracture*)):TI,AB,KY

\#10("Rancho Los Amigos Scale"):TI,AB,KY

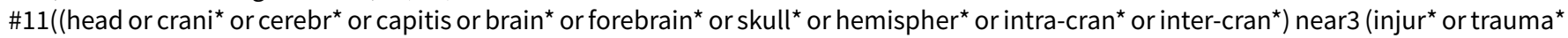
or damag* or wound ${ }^{\star}$ or fracture* or contusion $\left.\left.{ }^{\star}\right)\right): T I, A B, K Y$

\#12(Diffuse near3 axonal near3 injur ${ }^{\star}$ ):TI,AB, KY

\#13((head or crani* or cerebr* or brain* or intra-cran* or inter-cran*) near3 (haematoma* or hematoma* or haemorrhag* or hemorrhag* or bleed ${ }^{\star}$ or pressure)):TI,AB,KY

\#14(\#1 OR \#2 OR \#3 OR \#4 OR \#5 OR \#6 OR \#7 OR \#8 OR \#8 OR \#9 OR \#10 OR \#11 OR \#12 OR \#13)

\#15MESH DESCRIPTOR Hypothermia, Induced EXPLODE ALL TREES

\#16MESH DESCRIPTOR Cryotherapy EXPLODE ALL TREES

\#17MESH DESCRIPTOR Body Temperature EXPLODE ALL TREES

\#18(hypotherm* ${ }^{\star}$ or normotherm ${ }^{\star}$ or cool $^{*}$ or cold ${ }^{\star}$ or temperature* or cryother $^{\star}$ or cryogen $^{\star}$ or cryotreat ${ }^{\star}$ ):TI,AB,KY 
\#19(\#15 OR \#16 OR \#17 OR \#18)

\#20\#14 AND \#19

\#21* NOT INMEDLINE NOT INEMBASE

\#22\#20 AND \#21

[The update search in June 2017 was not limited by line 21]

Ovid MEDLINE(R), Ovid MEDLINE(R) In-Process \& Other Non-Indexed Citations, Ovid MEDLINE(R) Daily and Ovid OLDMEDLINE(R) to 1 June 2017

1. exp Craniocerebral Trauma/

2. exp Brain Edema/

3. exp Glasgow Coma Scale/

4. exp Glasgow Outcome Scale/

5. exp Unconsciousness/

6. exp Cerebrovascular Trauma/

7. ((head or crani\$ or cerebr\$ or capitis or brain\$ or forebrain\$ or skull\$ or hemispher\$ or intra-cran\$ or inter-cran\$) adj3 (injur\$ or trauma

$\$$ or damag\$ or wound\$ or fracture $\$$ or contusion\$)).ab,ti.

8. ((head or crani\$ or cerebr\$ or brain\$ or intra-cran\$ or inter-cran\$) adj3 (haematoma\$ or hematoma\$ or haemorrhag\$ or hemorrhag\$ or bleed\$ or pressure)).ti,ab.

9. (Glasgow adj3 (coma or outcome) adj3 (scale\$ or score\$)).ab,ti.

10. "rancho los amigos scale".ti,ab.

11. ("diffuse axonal injury" or "diffuse axonal injuries").ti,ab.

12. ((brain or cerebral or intracranial) adj3 (oedema or edema or swell\$)).ab,ti.

13. ((unconscious $\$$ or coma $\$$ or concuss $\$$ or 'persistent vegetative state') adj3 (injur\$ or trauma $\$$ or damag\$ or wound\$ or fracture\$)).ti,ab.

14. or/1-13

15. exp Hypothermia, Induced/

16. exp Cryotherapy/

17. exp Body Temperature/

18. (hypotherm ${ }^{\star}$ or normotherm ${ }^{\star}$ or cool $^{\star}$ or cold $^{\star}$ or temperature ${ }^{\star}$ or cryother $^{\star}$ or cryogen $^{\star}$ or cryotreat $^{\star}$ ).ab,ti.

19. 18 or 16 or 17 or 15

20. 19 and 14

21. randomi?ed.ab,ti.

22. randomised controlled trial.pt.

23. controlled clinical trial.pt.

24. placebo.ab.

25. clinical trials as topic.sh.

26. randomly.ab.

27. trial.ti.

28. Comparative Study/

29. 21 or 22 or 23 or 24 or 25 or 26 or 27 or 28

30. (animals not (humans and animals)).sh.

31.29 not 30

32. 20 and 31

Embase Classic + Embase (OvidSP)

1. exp Craniocerebral Trauma/

2. exp Brain Edema/

3. exp Glasgow Coma Scale/

4. exp Glasgow Outcome Scale/

5. exp Unconsciousness/

6. exp Cerebrovascular Trauma/

7. ((head or crani\$ or cerebr\$ or capitis or brain\$ or forebrain $\$$ or skull\$ or hemispher\$ or intra-cran\$ or inter-cran\$) adj3 (injur\$ or trauma

$\$$ or damag $\$$ or wound $\$$ or fracture $\$$ or contusion $\$)) . a b, t i$.

8. ((head or crani\$ or cerebr\$ or brain\$ or intra-cran\$ or inter-cran\$) adj3 (haematoma\$ or hematoma\$ or haemorrhag\$ or hemorrhag\$ or bleed\$ or pressure)).ti,ab.

9. (Glasgow adj3 (coma or outcome) adj3 (scale\$ or score\$)).ab,ti.

10. "rancho los amigos scale".ti,ab.

11. ("diffuse axonal injury" or "diffuse axonal injuries").ti,ab.

12. ((brain or cerebral or intracranial) adj3 (oedema or edema or swell\$)).ab,ti.

13. ((unconscious $\$$ or coma $\$$ or concuss $\$$ or 'persistent vegetative state') adj3 (injur $\$$ or trauma $\$$ or damag $\$$ or wound $\$$ or fracture\$)).ti, ab. 14. or/1-13 
15. exp Hypothermia, Induced/

16. exp Cryotherapy/

17. exp Body Temperature/

18. (hypotherm ${ }^{\star}$ or normotherm ${ }^{\star}$ or cool ${ }^{\star}$ or cold $^{\star}$ or temperature ${ }^{\star}$ or cryother $^{\star}$ or cryogen $^{\star}$ or cryotreat ${ }^{\star}$ ).ab,ti.

19. 18 or 16 or 17 or 15

20. 19 and 14

21. exp Randomized Controlled Trial/

22. exp controlled clinical trial/

23. exp controlled study/

24. comparative study/

25. randomi?ed.ab,ti.

26. placebo.ab.

27. ${ }^{\star}$ Clinical Trial/

28. exp major clinical study/

29. randomly.ab.

30. (trial or study).ti.

31.21 or 22 or 23 or 25 or 26 or 27 or 28 or 29 or 30

32. exp animal/ not (exp human/ and exp animal/)

33. 31 not 32

34. 20 and 33

35. limit 34 to exclude medline journals

In June 2017 a new Embase search was run which included relevant Emtree Subject Headings (as listed below).

\section{Embase (1974 to 2017 Week 22)}

1 randomised controlled trial/

2 controlled clinical trial/

3 randomi\#ed.ti,ab,kw.

4 randomization/

5 placebo.ti,ab,kw.

6 placebo/

$7^{\star}$ Clinical Trial/

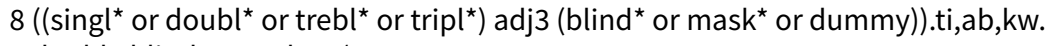

9 double blind procedure/

10 (RCT or at random or (random* adj (assign* or allocat* or divid* or division or number))).ti,ab,kw.

11 trial.ti.

12 or/1-11

13 ((animal or nonhuman) not (human and (animal or nonhuman))).de.

14 (12 not 13)

15 head injury/

16 exp brain injury/

17 cerebrovascular accident/

18 exp brain hemorrhage/

19 brain edema/

20 intracranial pressure/

21 brain perfusion/

22 exp brain injury assessment/

23 exp unconsciousness/

24 ((head or crani* or cerebr* or capitis or brain* or forebrain* or skull* or hemispher* or intra-cran* or

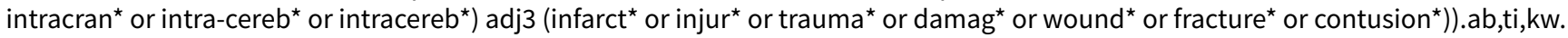

25 ((head or crani* or cerebr ${ }^{\star}$ or brain* or intra-cran* or intracran* or intra-cereb* or intracereb*) adj3

(haematoma* or hematoma* or haemorrhag* or hemorrhag* or hernia* or bleed ${ }^{\star}$ or pressure or hypertension or oedema or edema or swell $\left.{ }^{\star}\right)$.ti,ab,kw.

26 (Glasgow adj3 (coma or outcome) adj3 (scale* or score*)).ab,ti,kw.

27 rancho los amigos scale.ti,ab,kw.

28 diffuse axonal injur*.ti,ab,kw.

29 ((unconscious ${ }^{\star}$ or coma* or concuss ${ }^{\star}$ or postconcuss ${ }^{\star}$ or 'persistent vegetative state') adj3 (injur ${ }^{\star}$ or trauma* or damag* or wound $^{\star}$ or $^{*}$ fracture*)).ti,ab,kw.

30 (subarachnoid h?emorrhage or tSAH).ti,ab,kw.

31 ((midbrain or mid brain) adj syndrome).ti,ab,kw.

32 (TBI or mTBI or sTBI).ti,ab,kw.

33 or/15-32 
34 (14 and 33)

35 exp induced hypothermia/

36 exp cryotherapy/

37 exp body temperature/

38 (hypotherm ${ }^{\star}$ or normotherm ${ }^{\star}$ or cool ${ }^{\star}$ or cold ${ }^{\star}$ or temperature ${ }^{\star}$ or cryother ${ }^{\star}$ or cryogen ${ }^{\star}$ or cryotreat ${ }^{\star}$ ).ab,ti,kw.

39 or/35-38

40 (34 and 39)

$41\left(2016^{\star}\right.$ or $\left.2017^{\star}\right) \cdot y r, d d$.

42 (40 and 41)

PubMed (1 June 2017)

((((hypotherm[Title/Abstract] OR normotherm*[Title/Abstract] OR cool*[Title/Abstract] OR cold*[Title/Abstract] OR temperature*[Title/ Abstract] OR cryother [Title/Abstract] OR cryogen*[Title/Abstract] OR cryotreat*[Title/Abstract])) OR ((("Hypothermia, Induced"[Mesh]) OR "Cryotherapy"[Mesh:NoExp]) OR "Body Temperature"[Mesh]))) AND (((((pubmednotmedline[sb] OR (pubstatusnihms OR pubstatuspmcsd AND publisher[sb])))) AND (((((((("Comparative Study"[Publication Type]) OR "Randomized Controlled Trial"[Publication Type]) OR "Controlled Clinical Trial"[Publication Type])) OR (((((((randomised[Title/Abstract]) OR randomised[Title/Abstract]) OR placebo[Title/Abstract]) OR randomly[Title/Abstract]) OR trial[Title/Abstract]) OR groups[Title/Abstract]) OR group[Title/Abstract])))) AND (((Craniocerebral Trauma [mh] OR Brain Edema [mh] OR Glasgow Coma Scale [mh] OR Glasgow Outcome Scale [mh] OR Unconsciousness [mh] OR Cerebrovascular Trauma [mh])) OR ((((injury*[Title/Abstract] OR injuries[Title/Abstract] OR trauma[Title/Abstract] OR damage[Title/Abstract] OR damaged[Title/Abstract] OR wound*[Title/Abstract] OR fracture*[Title/Abstract] OR contusion*[Title/ Abstract] OR haematoma*[Title/Abstract] OR hematoma*[Title/Abstract] OR haemorrhag*[Title/Abstract] OR hemorrhag*[Title/ Abstract] OR bleed*[Title/Abstract] OR pressure[Title/Abstract]))) AND (head[Title/Abstract] or cranial[Title/Abstract] or cerebral[Title/ Abstract] or brain*[Title/Abstract] or intra-cranial[Title/Abstract] or inter-cranial[Title/Abstract]) AND (haematoma*[Title/Abstract] or hematoma*[Title/Abstract] or haemorrhag*[Title/Abstract] or hemorrhage*[Title/Abstract] or bleed*[Title/Abstract] or pressure[Title/ Abstract]) OR (Glasgow[Title/Abstract] AND scale[Title/Abstract]) OR ("diffuse axonal injury"[Title/Abstract]) OR ("diffuse axonal injuries"[Title/Abstract]) OR ("persistent vegetative state"[Title/Abstract]) OR (unconscious*[Title/Abstract]) OR coma*[Title/Abstract] OR concuss*[Title/Abstract])))))

ISI Web of Science: Science Citation Index Expanded (SCI-EXPANDED) and Conference Proceedings Citation Index-Science (CPCI-S) (1 June 2017)

\# 9\#8 AND \#7 AND \#6

\# 8TS=(injury* OR injuries OR trauma OR damage OR damaged OR wound* OR fracture* OR contusion* OR haematoma* OR hematoma* OR haemorrhag ${ }^{\star}$ OR hemorrhag* OR bleed ${ }^{\star}$ OR pressure)

\# 7TS=(hypotherm ${ }^{\star}$ OR normotherm ${ }^{\star}$ OR cool ${ }^{\star}$ OR cold $^{\star}$ OR temperature ${ }^{\star}$ OR cryother $^{\star}$ OR cryogen ${ }^{\star}$ OR cryotreat $^{\star}$ )

\# 6\#5 AND \#4

\# 5TS=(human $\left.{ }^{\star}\right)$

\# 4\#3 OR \#2 OR \#1

\# 3TS $=\left(\left(\right.\right.$ singl ${ }^{\star}$ OR doubl ${ }^{\star}$ OR trebl ${ }^{\star}$ OR tripl $\left.{ }^{\star}\right)$ SAME $\left(\right.$ blind $^{\star}$ OR mask $\left.\left.{ }^{\star}\right)\right)$

\# 2TS=(controlled clinical trial OR controlled trial OR clinical trial OR placebo)

\# 1TS=(randomised OR randomised OR randomly OR random order OR random sequence OR random allocation OR randomly allocated $\mathrm{OR}$ at random OR randomised controlled trial)

Clinicaltrials.gov (1 June 2017)

INFLECT EXACT "Interventional" [STUDY-TYPES] AND ( injury* OR injuries OR trauma OR damage OR damaged OR wound* OR fracture* OR contusion* OR haematoma* OR hematoma* OR haemorrhag* OR hemorrhag* OR bleed* OR pressure ) [DISEASE] AND ( hypothermia OR normothermia OR cool* OR cold ${ }^{\star}$ OR temperature* OR cryotheraphy ) [TREATMENT]

WHO International Clinical Trials Registry Platform (1 June 2017)

Condition: (injury* OR injuries OR trauma OR damage OR damaged OR wound* OR fracture* OR contusion* OR haematoma* OR hematoma* OR haemorrhag* OR hemorrhag* OR bleed* OR pressure)

AND

Intervention: hypotherm ${ }^{\star}$ OR normotherm ${ }^{\star}$ OR cool ${ }^{\star}$ OR cold ${ }^{\star}$ OR temperature* OR cryother ${ }^{\star}$ OR cryogen* OR cryotreat ${ }^{\star}$

Recruitment: ALL

ISRCTN Registry (21 March 2016)

Text search: (injury OR injuries OR trauma OR contusion OR haematoma OR hematoma OR haemorrhage OR hemorrhage OR bleed) AND (hypothermia OR normothermia OR cryother* OR cryogen ${ }^{\star}$ OR cryotreat ${ }^{\star}$ ) 


\section{Appendix 2. Previous search strategies}

\section{Search methods}

- Cochrane Injuries Group Specialised Register (12 Jan 2009);

- CENTRAL (The Cochrane Library Issue 1, 2009);

- MEDLINE (1950 to March 2009);

- PubMed (searched 6 April 2009);

- EMBASE (1980 to week 14, March 2009);

- ISI Web of Science: Science Citation Index Expanded (SCI-EXPANDED) 1970 to April 2009 and Conference Proceedings Citation IndexScience (CPCI-S) 1990 to 7 April 2009;

- Controlled Trials metaRegister of trials (mRCT) http://www.controlled-trials.com/mrct/ (12 January 2009);

- Zetoc (12 January 2009).

\section{Injuries Group's Specialised Register (searched 12 January 2009)}

((injur ${ }^{\star}$ or trauma* or lesion* or damage* or wound* or oedema* or edema* or fracture* or contusion* or concus ${ }^{\star}$ or commotion* or pressur $^{\star}$ ) and (head or crani* or capitis or brain* or forebrain* or skull* or hemisphere or intracran ${ }^{\star}$ or orbit $\left.^{\star}\right)$ ) and $\left(\right.$ hypotherm $^{\star}$ or $^{\star}$ normotherm ${ }^{\star}$ or cool $^{\star}$ or cold ${ }^{\star}$ or temperature ${ }^{\star}$ or cryother $^{\star}$ or cryogen $^{\star}$ or cryotreat $^{\star}$ )

\section{CENTRAL (The Cochrane Library 2009, Issue 1)}

\#1MeSH descriptor Craniocerebral Trauma explode all trees \#2MeSH descriptor Cerebrovascular Trauma explode all trees \#3MeSH descriptor Brain Edema explode all trees \#4(brain or cerebral or intracranial) near3 (oedema or edema or swell ${ }^{\star}$ ) \#5MeSH descriptor Glasgow Coma Scale explode all trees \#6MeSH descriptor Glasgow Outcome Scale explode all trees \#7MeSH descriptor Unconsciousness explode all trees \#8glasgow near3 (coma or outcome) near3 (score or scale) \#9(Unconscious ${ }^{\star}$ or coma* or concuss* or 'persistent vegetative state') near 3 (injur ${ }^{\star}$ or trauma* or damag* or wound ${ }^{\star}$ or fracture $^{\star}$ ) \#10"Rancho Los Amigos Scale"

\#11(head or crani* or cerebr ${ }^{\star}$ or capitis or brain* or forebrain* or skull* or hemispher ${ }^{\star}$ or intra-cran* or inter-cran ${ }^{\star}$ ) near3 (injur ${ }^{\star}$ or trauma $^{*}$ or damag* or wound ${ }^{\star}$ or fracture* or contusion*)

\#12Diffuse near3 axonal near3 injur*

\#13(head or crani* or cerebr ${ }^{\star}$ or brain* or intra-cran* or inter-cran*) near3 (haematoma* or hematoma* or haemorrhag* ${ }^{\star}$ or hemorrhag $^{\star}$ or bleed* or pressure)

\#14(\#1 OR \#2 OR \#3 OR \#4 OR \#5 OR \#6 OR \#7 OR \#8 OR \#8 OR \#9 OR \#10 OR \#11 OR \#12 OR \#13)

\#15MeSH descriptor Hypothermia, Induced explode all trees

\#16MeSH descriptor Cryotherapy explode all trees

\#17MeSH descriptor Body Temperature explode all trees

\#18hypotherm ${ }^{\star}$ or normotherm ${ }^{\star}$ or cool ${ }^{\star}$ or cold ${ }^{\star}$ or temperature ${ }^{\star}$ or cryother $^{\star}$ or cryogen $^{\star}$ or cryotreat ${ }^{*}$

\#19(\#15 OR \#16 OR \#17 OR \#18)

\#20(\#14 AND \#19)

\#21neonat*

\#22(\#20 AND NOT \#21)

\section{MEDLINE (1966 to March week 4, 2009)}

1.exp Craniocerebral Trauma/

2.exp Brain Edema/

3.exp Glasgow Coma Scale/

4.exp Glasgow Outcome Scale/

5.exp Unconsciousness/

6.exp Cerebrovascular Trauma/

7.((head or crani\$ or cerebr\$ or capitis or brain\$ or forebrain\$ or skull\$ or hemispher\$ or intra-cran\$ or inter-cran\$) adj3 (injur\$ or trauma \$ or damag\$ or wound\$ or fracture\$ or contusion\$)).ab,ti.

8.((head or crani\$ or cerebr\$ or brain\$ or intra-cran\$ or inter-cran\$) adj3 (haematoma or hematoma\$ or haemorrhag\$ or hemorrhag\$ or bleed\$ or pressure)).ti,ab.

9.(Glasgow adj3 (coma or outcome) adj3 (scale\$ or score\$)).ab,ti.

10."rancho los amigos scale".ti,ab.

11.("diffuse axonal injury" or "diffuse axonal injuries").ti,ab.

12.((brain or cerebral or intracranial) adj3 (oedema or edema or swell\$)).ab,ti.

13. ((unconscious $\$$ or coma $\$$ or concuss $\$$ or 'persistent vegetative state') adj3 (injur\$ or trauma $\$$ or damag\$ or wound\$ or fracture\$)).ti,ab. 
14.or/1-13

15.(randomised or randomised or randomly or random order or random sequence or random allocation or randomly allocated or at random or controlled clinical trial\$).tw, hw.

16.clinical trial.pt.

17.randomised controlled trial.pt.

18.15 or 16 or 17

19.exp models, animal/

20.exp Animals/

21.exp Animal Experimentation/

22.exp Disease Models, Animal/

23.exp Animals, Laboratory/

24.or/19-23

25. Humans/

26.24 not 25

27.18 not 26

28.14 and 27

29.exp Hypothermia, Induced/

30.exp Cryotherapy/

31.exp Body Temperature/

32. (hypotherm ${ }^{\star}$ or normotherm ${ }^{\star}$ or cool $^{\star}$ or cold ${ }^{\star}$ or temperature or cryother $^{\star}$ or cryogen $^{\star}$ or cryotreat ${ }^{\star}$ ).ab,ti.

33.or/29-32

34.neonat ${ }^{\star}$.ab,ti.

35.33 not 34

36.28 and 35

\section{PubMed 6 April 2009 (last 90 days)}

\#1Craniocerebral Trauma [mh] OR Brain Edema [mh] OR Glasgow Coma Scale [mh] OR Glasgow Outcome Scale [mh] OR Unconsciousness [mh] OR Cerebrovascular Trauma [mh] OR ((head or cranial or cerebral or brain* or intra-cranial or inter-cranial) AND (haematoma* or hematoma* or haemorrhag* or hemorrhage* or bleed* or pressure)) OR (Glasgow AND scale) OR ("diffuse axonal injury" OR "diffuse axonal injuries") or ("persistent vegetative state") OR ((unconscious^ OR coma* OR concuss`) AND (injury* OR injuries OR trauma OR damage OR damaged OR wound ${ }^{\star}$ OR fracture* OR contusion* OR haematoma* OR hematoma* OR haemorrhag* OR hemorrhag* OR bleed* OR pressure))

\#2(randomised OR randomised OR randomly OR random order OR random sequence OR random allocation OR randomly allocated OR at random OR randomised controlled trial [pt] OR controlled clinical trial [pt] OR randomised controlled trials [mh]) NOT ((models, animal[mh] OR Animals[mh] OR Animal Experimentation[mh] OR Disease Models, Animal[mh] OR Animals, Laboratory[mh]) NOT (Humans[mh]))

$\# 31$ and 2

\#4("Hypothermia, Induced"[Mesh] OR "Cryotherapy"[Mesh]) OR "Body Temperature"[Mesh]

\#5hypotherm ${ }^{\star}$ or normotherm ${ }^{\star}$ or cool ${ }^{*}$ or cold ${ }^{\star}$ or temperature ${ }^{\star}$ or cryother $^{\star}$ or cryogen $^{\star}$ or cryotreat* Field: Title/Abstract

\#64 or 5

\#7Neonat* Field: Title/Abstract

\#86 not 7

\#93 and 8

\section{Embase 1980 to (week 14) March 2009}

1.exp Brain Injury/

2.exp Brain Edema/

3.exp Glasgow Coma Scale/

4.exp Glasgow Outcome Scale/

5.exp Rancho Los Amigos Scale/

6.exp Unconsciousness/

7.((brain or cerebral or intracranial) adj3 (oedema or edema or swell\$)).ab,ti.

8.((head or crani\$ or cerebr $\$$ or capitis or brain $\$$ or forebrain\$ or skull\$ or hemispher $\$$ or intra-cran $\$$ or inter-cran\$) adj3 (injur\$ or trauma $\$$ or damag\$ or wound\$ or fracture $\$$ or contusion $\$)$ ).ab,ti.

9.(Glasgow adj3 (coma or outcome) adj3 (scale\$ or score\$)).ab,ti.

10.Rancho Los Amigos Scale.ab,ti.

11.((unconscious $\$$ or coma $\$$ or concuss $\$$ or 'persistent vegetative state') adj3 (injur\$ or trauma $\$$ or damag $\$$ or wound\$ or fracture\$)).ti,ab. 12.Diffuse axonal injur\$.ab,ti.

13.((head or crani\$ or cerebr\$ or brain\$ or intra-cran\$ or inter-cran\$) adj3 (haematoma\$ or hematoma\$ or haemorrhag\$ or hemorrhag \$ or bleed\$ or pressure)).ab,ti.

14.or/1-13

15.exp animal model/

16.Animal Experiment/ 
17.exp ANIMAL/

18.exp Experimental Animal/

19.15 or 16 or 17 or 18

20.Human/

21.19 not 20

22.(randomised or randomised or randomly or random order or random sequence or random allocation or randomly allocated or at random or controlled clinical trial\$).tw, hw.

23.exp clinical trial/

24.22 or 23

25.24 not 21

26.14 and 25

27.exp INDUCED HYPOTHERMIA/

28.exp PROFOUND INDUCED HYPOTHERMIA/

29.exp CRYOTHERAPY/

30.exp Body Temperature/

31.(hypotherm ${ }^{\star}$ or normotherm ${ }^{\star}$ or cool ${ }^{\star}$ or cold ${ }^{\star}$ or temperature* or cryother $^{\star}$ or cryogen $^{\star}$ or cryotreat $\left.^{\star}\right)$. ab,ti.

32.27 or 28 or 29 or 30 or 31

33.neonat*.ab,ti.

34.32 not 33

35.26 and 34

Controlled Trials metaRegister of trials (mRCT) http://www.controlled-trials.com/mrct/ (searched 12 January 2009)

((injur ${ }^{\star}$ or trauma* or damage ${ }^{\star}$ ) and (head or crani ${ }^{\star}$ or brain* or forebrain* or intracran*)) and (hypotherm* or normotherm ${ }^{\star}$ or cool ${ }^{\star}$ or cold $^{\star}$ or temperature* or cryother $\left.^{\star}\right)$

ISI Web of Science: Science Citation Index Expanded (SCI-EXPANDED) 1970 to April 2009 and Conference Proceedings Citation IndexScience (CPCI-S) 1990 to 7 April 2009

1.Topic $=\left(\left(\right.\right.$ injur ${ }^{\star}$ or trauma* or lesion* or damage* or wound ${ }^{\star}$ or oedema* or edema* or fracture* or contusion* or concus* or commotion* or pressur ${ }^{\star}$ ) AND (head or crani* or capitis or brain* or forebrain* or skull* or hemisphere or intracran* or orbit $\left.{ }^{\star}\right)$ ) AND Topic=(hypotherm ${ }^{\star}$ or normotherm ${ }^{\star}$ or cool* or cold $^{\star}$ or temperature ${ }^{\star}$ or cryother $^{\star}$ or cryogen $^{\star}$ or cryotreat $\left.^{\star}\right)$ NOT Topic $=\left(\right.$ neonat $\left.^{\star}\right)$

2.Topic=(randomised OR randomised OR randomly OR random order OR random sequence OR random allocation OR randomly allocated OR at random OR randomised controlled trial OR controlled clinical trial OR randomised controlled trials OR controlled trial OR clinical trial) NOT Topic $=\left(\right.$ animal model ${ }^{\star}$ OR Animals OR Animal Experiment ${ }^{\star}$ OR Laboratory animals* or animal disease model $^{\star}$ )

3.1 and 2

ZETOC (searched 12 January 2009)

Hypotherm* head injur ${ }^{\star}$ trial $^{\star}$

Hypotherm* head injur* random*

Hypotherm* head injur* control*

Hypotherm* brain injur* trial*

Hypotherm* brain injur* random*

Hypotherm* brain injur* ${ }^{\star}$ control ${ }^{\star}$

Hypotherm* head trauma* trial* $^{*}$

Hypotherm* head trauma* random*

Hypotherm* head trauma* control* $^{*}$

Hypotherm* brain trauma* trial*

Hypotherm* brain trauma* random*

Hypotherm* brain trauma* control* $^{*}$

\section{The following search strategy was used for the initial search in 1998:}

The Specialist Trials Register for the Injuries Group was searched in May 1998 for any relevant randomised trials relating to temperature control using the search terms: hypotherm* OR normotherm* OR cool* OR cold* OR temperature.

The search strategy for the register is primarily an electronic search of both MEDLINE and CENTRAL, supplemented by various handsearching activities listed in the Group details. This was supplemented by a comprehensive EMBASE search, also performed in May 1998 as follows, to identify all potential RCTs involving human head injury and temperature control from 1980 onwards:

001 exp head injury/

002 pneumocephalus/

003 cerebrospinal fluid/ 
004 otorrhea/

005 exp skull fracture/

006 exp spine fracture/

007 Cerebrospinal Fluid Rhinorrhea/

008 exp asphyxia/

009 exp spine injury/

010 helmet/

011 brain protection/

012 brain edema/

013 exp brain hemorrhage/

014 brain hypoxia/

015 coma/

016 persistent vegetative state/

017 Traumatic Epilepsy/

018 or/1-17

019 (head or brain or cerebr\$ or skull or crani\$ or spin\$).tw.

020 (wound\$ or injur\$ or trauma\$ or oedema\$ or edema\$).tw.

021 damage\$.tw.

02220 or 21

02319 and 22

02418 or 23

025 human/

026 " 888 ".tg.

02725 or 26

028 Nonhuman/

029 " 777 ".tg.

03028 or 29

03127 and 30

03230 not 31

033 clinical trial/

034 Multicenter Study/

035 phase 2 clinical trial/

036 phase 3 clinical trial/

037 Phase 4 Clinical Trial/

038 Randomized Controlled Trial/

039 controlled study/

040 meta analysis/

041 crossover procedure/

042 double blind procedure/

043 Single Blind Procedure/

044 randomization/

045 Major Clinical Study/

046 placebo/

047 drug comparison/

048 clinical study/

049 "0197".tg.

050 "0150".tg.

051 "03738".dc.

052 (clin\$ adj25 trial\$).tw.

053 ((singl\$ or doubl\$ or tripl\$ or trebl\$) adj25 (blind\$ or mask\$)).tw.

054 placebo\$.tw.

055 random $\$$.tw.

056 control\$.tw.

057 or/33-56

05824 not 32

059 Induced Hypothermia/

060 Profound Induced Hypothermia/

061 exp temperature/

062 exp low temperature procedures/

063 cold/

064 cold air/

065 cold exposure/

Hypothermia for traumatic brain injury (Review) 
066 (hypotherm\$ or normotherm\$ or cool\$ or cold\$ or temperature\$).tw.

067 or/59-66

06858 and 67

06968 and 57

The searches were supplemented by further handsearching of conference proceedings and abstracts as follows:

- International Conference on Recent Advances in Neurotraumatology, Italy 1996

- 2nd International Neurotrauma Symposium, Glasgow 1993

- 3rd International Neurotrauma Symposium, Toronto 1995

- 4th International Neurotrauma Symposium, Seoul 1997

- 27th Meeting of the Society for Critical Care Medicine, USA 1998

- 10th International Symposium on Intracranial Pressure, USA 1997

WHAT'S NEW

Date Event Description

5 June $2017 \quad$ New citation required but conclusions have not changed

The review has been updated with data from nine new studies and five studies that were previously excluded but re-assessed for eligibility and included in this update. Meta-analysis was not performed owing to unexplained differences between studies.

5 June $2017 \quad$ New search has been performed

The review has been updated by a new team of authors.

We ran a pre-publication search on 1 June 2017, and identified one study which we have listed in the Characteristics of studies awaiting classification section. We will incorporate this study in the next update as appropriate.

\section{H I S T O R Y}

Protocol first published: Issue 2, 1999

Review first published: Issue 2, 1999

\begin{tabular}{lll}
\hline Date & Event & Description \\
\hline 8 July 2009 & New search has been performed & $\begin{array}{l}\text { The review has been updated with data from one new trial (Har- } \\
\text { ris 2009). The results have been amended accordingly. The con- } \\
\text { clusions remain the same. }\end{array}$ \\
\hline
\end{tabular}

7 April $2009 \quad$ New search has been performed

The search has been updated to 7 April 2009. Two new trials have been identified as meeting the inclusion criteria, but the publications are not yet available (Bayir 2009, Harris 2009). Data from these trials will be included in the next update of this review.

Other sections of the review have also been amended:

- The Background section has been updated.

- The last version of this review was updated to January 2009, with ten trials in 'Studies awaiting classification' pending confirmation of randomisation. The review authors have been unable to confirm these trials are randomised controlled trials, and they have been excluded. 


\begin{tabular}{lll}
\hline Date Event Description & Den
\end{tabular}

- With this update, and to ensure consistency across included trials, all included trials have been re-assessed against the inclusion criteria. One trial that was included in previous versions of the review has now been excluded (Meissner 1998) as there is no mention of randomisation.

- The results have been amended accordingly; the conclusions of the review remain the same.

- The details of two ongoing trials have been included (Beca 2006, Maekawa 2002).

26 January $2009 \quad \begin{aligned} & \text { New citation required and conclusions } \\ & \text { have changed }\end{aligned}$
have changed
Review updated; search updated to 12 January 2009.

Data from one new study is included (Hutchinson 2008). The results of the review have been amended accordingly.

One further study was excluded (Gal 2002).

31 October $2008 \quad$ New citation required and conclusions
have changed view have been amended accordingly.
Eight new trials are included in this update. The results of the re-

One trial currently in 'studies awaiting assessment' (Hutchison 2008a) was identified after the search was completed for this update. Data from this trial will be included in the review for Issue 2, 2009.

The title has been changed from 'Therapeutic hypothermia for head injury' to 'Hypothermia for traumatic head injury'.

The authors of the review have changed.

9 July $2008 \quad$ Amended

The version of this review published in July 2008 mistakenly included three additional trials in the table of included studies and references sections.

Data from these three studies were not included in the review. The text of the review is the same as the 28 July 2004 update.

\begin{tabular}{lll}
\hline 14 May 2008 & Amended & Converted to new review format. \\
\hline 28 July 2004 & New search has been performed & $\begin{array}{l}\text { Substantive amendment. New studies found and included or ex- } \\
\text { cluded. }\end{array}$ \\
& $\begin{array}{l}\text { Two more trials have been included, and one added to the await- } \\
\text { ing assessment list as we have not been able to obtain a copy of } \\
\text { the trial. } \\
\text { Conclusions have been reviewed and compared to those found } \\
\text { in a review of the topic in JAMA. }\end{array}$ \\
\end{tabular}

Four studies were included, which were published since the original version of this review.

Quantitative synthesis of the incidence of pulmonary infections was conducted in the 2001 update. 


\section{CONTRIBUTIONS OF AUTHORS}

David Signorini wrote the protocol, performed the searches and reviewed the titles and abstracts, extracted the data, performed the analyses and wrote the draft of the review. Phil Alderson (PA) reviewed the manuscripts of potential trials, extracted the data and edited the draft review.

For the 2001 update, the Injuries Group performed the search and screened studies. PA and Chirag Gadkary assessed eligibility, extracted data, performed the analysis and redrafted the text.

For the 2004 update, the Injuries Group performed the search and screened studies. PA and the Injuries Group extracted data, and PA performed the analysis and rewrote the text.

For the 2008 update, the search was carried out by Karen Blackhall (KB) of the Cochrane Injuries Group. Emma Sydenham (ES) and lan Roberts (IR) assessed trial eligibility and applied the selection criteria. ES extracted data, and IR checked for accuracy. ES updated the text of the review. IR and ES performed the analysis and edited the manuscript. PA checked the final manuscript of the update.

KB performed the search for the January 2009 update. ES and IR assessed trial eligibility and applied the selection criteria. ES extracted the data and IR checked the extracted data for accuracy. ES updated the text of the review. IR and ES performed the analysis and edited the manuscript. PA checked the final manuscript of the update.

In April 2009, KB updated the search for trials. ES and IR assessed trial eligibility and applied the selection criteria. ES and IR re-assessed all previously included trials against the inclusion criteria. All authors agreed that the Meissner 1998 study should be excluded. ES updated the text of the review. IR and PA checked the final manuscript of the update.

ES included data from the Harris 2009 trial for the July 2009 update. IR and PA checked the extracted data. All authors approved the manuscript for publication.

Sharon R Lewis (SRL) co-ordinated the 2017 review update. Database searches were carried out by Deidre Beecher. SRL screened titles and abstracts, assessed full-text publications for eligibility, carried out data extraction and updated the text of the review. Second review authors at each stage were one of: Andrew Butler; David Evans; Oliver Schofield-Robinson; and PA. PA checked the final manuscript of the update.

\section{DECLARATIONSOF INTEREST}

Phil Alderson: None known

Sharon R Lewis: None known

David JW Evans: None known

Andrew R Butler: None known

Oliver J Schofield-Robinson: None known

\section{SOURCES OF SUPPORT}

\section{Internal sources}

- DFS was supported by MRC project grant G9604637, UK.

- NHS R\&D Programme, UK.

\section{External sources}

- CG was supported by the Doris Duke Research Fellowship, USA.

- National Institute for Health Research (NIHR), UK.

This project was supported by the UK National Institute for Health Research, through Cochrane Infrastructure funding to the Cochrane Injuries Group. The views and opinions expressed are those of the authors and do not necessarily reflect those of the Systematic Reviews Programme, NIHR, NHS or the Department of Health. 


\section{DIFFERENCES BETWEEN PROTOCOL AND REVIEW}

\section{Differences between the current version and previous version of the review (Sydenham 2009b)}

Previous versions of the review were titled Hypothermia for traumatic head injury (Alderson 2004; Gadkary 2002; Sydenham 2009a; Sydenham 2009b). We changed the title to Hypothermia for traumatic brain injury and made appropriate edits throughout the review to reflect this change.

We edited the review Background and Methods sections to incorporate all Methodological Expectations of Cochrane Intervention Reviews (MECIR).

We edited the inclusion criteria to include studies with mixed head injuries if fewer than $10 \%$ of participants were described as having an open head injury, as we did not want to exclude important studies on the basis that a very small proportion of participants had an open head injury.

We re-assessed studies that were excluded due to insufficient information on methods of randomisation in Sydenham 2009b. We included five of these studies; we added the remaining three studies to Excluded studies. We removed the references of studies excluded in previous versions of the review; the studies in Excluded studies relate to searches and decisions made for this update.

We updated the 'Risk of bias' tables to incorporate assessment of all domains for all studies. We updated the Characteristics of included studies tables to incorporate all MECIR requirements.

The 2008 update of this review evaluated study quality by allocation concealment only. The incidence of pneumonia was also stratified by study quality.

\section{INDEX TERMS}

\section{Medical Subject Headings (MeSH)}

${ }^{\star}$ Hypothermia, Induced [adverse effects] [mortality]; Craniocerebral Trauma [mortality] [ ${ }^{\star}$ therapy]; Pneumonia [etiology]; Randomized Controlled Trials as Topic

\section{MeSH check words}

Humans 